\title{
《中国植被志》研编内容与规范
}

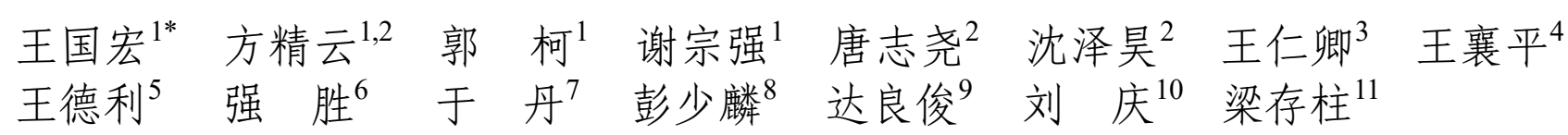

${ }^{1}$ 中国科学院植物研究所植被与环境变化国家重点实验室, 北京 $100093 ;{ }^{2}$ 北京大学城市与环境学院, 北京大学生态研究中心, 北京 $100871 ;{ }^{3}$ 山东大 学生命科学学院, 济南 $250100 ;{ }^{4}$ 北京林业大学林学院, 北京 $100083 ;{ }^{5}$ 东北师范大学环境学院, 长春 $130024 ;{ }^{6}$ 南京农业大学生命科学学院, 南京 $210095 ;{ }^{7}$ 武汉大学生命科学学院, 武汉 $430072 ;{ }^{8}$ 中山大学生命科学学院, 广州 $442000 ;{ }^{9}$ 华东师范大学生态与环境科学学院, 上海 $200241 ;{ }^{10}$ 中国科 学院成都生物研究所, 成都 $610041 ;{ }^{11}$ 内蒙古大学生态与环境学院, 呼和浩特 010021

摘 要 植被志是基于植被(或植物群落)调查资料, 全面记叙植被的外貌、物种组成、结构和功能, 以及地理分布和生境条 件等特征, 并对同类植被进行归纳和总结的志书。《中国植被志》是第一部对中国植被进行全面记述的志书, 预计完成约48 卷110册。在借鉴《中国植被》(1980)(简称“80方案”)植被分类基本原则的基础上，《中国植被志》将对中国植被分类系统的高 级分类单位(植被型组、植被型和植被亚型)进行归纳和总结, 对中级和低级分类单位(群系组、群系、亚群系, 群从组、群从) 进行详细描述。植被高级分类单位的描述具有概括性质, 是在中国植被分类系统中级和低级分类单位描述的基础上, 对其在 全球和中国境内的地理分布、自然环境、群落外貌、植被类型及多样性、优势种或共优势种、生物多样性保育价值以及资源 现状等进行概述, 并对“80方案”相关内容进行修订和拓展, 将提供对中国植被基本特征客观、准确的记述。在植被中级和低 级分类单位中, 群系组描述的内容包括地理分布、自然环境、群落外貌、植被类型以及价值与保育等内容; 群系描述的主要 内容包括地理分布、自然环境、生态特征、物种组成、群落结构、群丛组和群丛的分类与描述、优势种的生物学特性、生物 量与生产力、植被动态与演替以及价值与保育等方面。作为植被志研编的核心内容, 群从组和群丛的分类与描述主要基于植 被调查资料, 采用数量分类方法, 根据群落结构和物种组成的差异划分出不同的植被类型, 并对其基本特征进行定量描述和 归纳。其中, 群落的层片结构、特定植被分类单元的特征种或特征种组的篮选与甄别是植被类型划分的关键环节; 而群落外 貌, 群落结构, 物种组成, 各类物种的生长习性、生境的偏适性等是群从组和群从描述与归纳的重点内容。该文提出了中国 植被中级和低级分类单位的命名方案, 其特点在于植被类型的科学名称中同时体现了植被分类单元特征种或优势种的名称 及其所属的高级植被分类单位(植被型组或植被型)的名称, 兼顾了植被名称的规范性与实用性。《中国植被志》的研编工作 由文献整编、群落调查、数据分析与整理、文本撰写等环节组成。该文对植被样方的调查与收集, 文献收集与整编, 气候、 土壤、地形等相关数据的来源及其整理方法, 植被分类方法, 植被命名, 植被分类单元描述的内容, 植被志章节编写大纲、体 裁及撰写等多个规范进行了详细的阐述或示例。

关键词 植被; 植被志; 植被分类; 植被命名; 植被描述; 群系组; 群系; 群丛组; 群丛

王国宏, 方精云, 郭柯, 谢宗强, 唐志尧, 沈泽吴, 王仁卿, 王襄平, 王德利, 强胜, 于丹, 彭少麟, 达良俊, 刘庆, 梁存柱 (2020). 《中国植被志》研编 内容与规范. 植物生态学报, 44, 128-178. DOI: 10.17521/cjpe.2019.0272

\section{Contents and protocols for the classification and description of Vegetation Formations, Alli- ances and Associations of vegetation of China}

WANG Guo-Hong $^{1 *}$, FANG Jing-Yun ${ }^{1,2}$, GUO Ke ${ }^{1}$, XIE Zong-Qiang ${ }^{1}$, TANG Zhi-Yao ${ }^{2}$, SHEN Ze-Hao ${ }^{2}$, WANG Ren-Qing ${ }^{3}$, WANG Xiang-Ping ${ }^{4}$, WANG De-Li ${ }^{5}$, QIANG Sheng ${ }^{6}$, YU Dan ${ }^{7}$, PENG Shao-Lin ${ }^{8}$, DA Liang-Jun ${ }^{9}$, LIU $\mathrm{Qing}^{10}$, and LIANG Cun-Zhu ${ }^{11}$

${ }^{1}$ State Key Laboratory of Vegetation and Environmental Change, Institute of Botany, Chinese Academy of Sciences, Beijing 100093 , China; ${ }^{2}$ Institute of Ecology, College of Urban and Environmental Sciences, Peking University, Beijing 100871, China; ${ }^{3}$ School of Life Sciences, Shandong University, Jinan 250100, China; ${ }^{4}$ College of Forestry, Beijing Forestry University, Beijing 100083, China; ${ }^{5}$ School of Environment, Northeast Normal University, Changchun 130024, China; ${ }^{6}$ School of Life Sciences, Nanjing Agricultural University, Nanjing 210095, China; ${ }^{7}$ College of Life Sciences, Wuhan University, Wuhan 430072, China; ${ }^{8}$ School of Life Sciences, Sun Yat-Sen University, Guangzhou 442000, China; ${ }^{9}$ School of Ecological and Environmental Sciences, East China Normal University, Shanghai 200241, China; ${ }^{10}$ Chengdu Institute of Biology, Chinese Academy of Sciences, Chengdu 610041, China; and ${ }^{11}$ School of Ecology and Environment, Inner Mongolia University, Hohhot 010021, China

收稿日期Received: 2019-10-15 接受日期Accepted: 2019-11-25

基金项目：国家科技基础性工作专项(2015FY210200)和国家科技基础资源调查专项(2019FY202300)。Supported by the Special Foundation for National Science and Technology Basic Research Program of China (2015FY210200), and the Special Foundation for National Science and Technology Basic Resources Investigation of China (2019FY202300).

* E-mail: ghwangaq@ibcas.ac.cn 


\section{Abstract}

Vegegraphy, a compound word of prefix "vege-" of "vegetation" and suffix of "-graphy" (description), is a series of monographs that describe species composition, structures, functions, distribution and environmental settings of a set of plant communities and/or their combinations. The Vegegraphy of China, which will be composed of 48 volumes and about 110 issues, is the first version to describe the medium-level units (Alliance Group, Alliance) and the lower-level units (Association Group, Association), and summarizes the higher-level units (Vegetation Formation Group, Vegetation Formation, Vegetation Subformation) in the Chinese Vegetation Classification System. The description of the higher-level units is highly generalized, mainly based on the data and evidences from the classification and description of the medium- and the lower-level classification units of the Chinese vegetation classification system, focusing on the geographic distribution, natural environment, community physiognomy, vegetation type and diversity, dominant species, values for biodiversity conservation, and the status of current vegetation resources at the scales of both worldwide and China. It is an important revision and expansion of the relevant content of Vegetation of China (1980) and will be the most authoritative and accurate description of the basic characteristics of Chinese vegetation. Alliance Group in each issue is briefly described on geographical distribution, natural environment, vegetation types, significance and conservation etc. Alliance as a key mediumlevel unit is to be described on several aspects, i.e., geographical distribution, natural environment, ecological characteristics, vegetation composition, vegetation structure, vegetation types and characteristics, biological characteristics of dominant species, biomass and productivity, vegetation dynamics and succession, and significance and conservation. As a core content of the above mentioned aspects, vegetation classification and description are conducted under the guidance of the " 80 scheme" of Vegetation of China, using vegetation survey data as credentials to quantitatively differentiate vegetation types accordingly. Specifically, a vegetation classification scheme is determined based on supraterraneous stratification, and a set of diagnostic species while vegetation descriptions focus on physiognomy, community structure, species composition, including quantitative features of dominant species, companion species, constant species and accidental species, as well as their environmental preferences. In this study, we first put forward a code of vegetation nomenclature for the medium-level units (Alliance Group, Alliance) and the lower-level units (Association Group, Association) in the Chinese Vegetation Classification System. According to this vegetation nomenclature, the name of a vegetation type is composed of the name of a diagnostic species (may also be a dominant species) of each layer of the vegetation type and the name of the higher-level units (Vegetation Formation or Vegetation Formation Group) to which it belongs, which guarantees both scientific soundness and practical sense of the vegetation nomenclature. Contents and protocols for the research and editing of "Vegegraphy of China", including vegetation survey and sample collection, literature compilation, climate, soil and topography data collection and compilation, vegetation classification, vegetation nomenclature, vegetation description outlines, are elaborated or exemplified in detail.

Key words vegetation; vegegraphy; vegetation classification; vegetation nomenclature; vegetation description; Alliance Group; Alliance; Association Group; Association

Wang GH, Fang JY, Guo K, Xie ZQ, Tang ZY, Shen ZH, Wang RQ, Wang XP, Wang DL, Qiang S, Yu D, Peng SL, Da LJ, Liu Q, Liang CZ (2020). Contents and protocols for the classification and description of Vegetation Formations, Alliances and Associations of vegetation of China. Chinese Journal of Plant Ecology, 44, 128-178. DOI: 10.17521/cjpe.2019.0272

植被是某一地段内所有植物群落的集合(方精 云等, 2020)。植被志(vegegraphy)则是“基于植被或 植物群落调查资料, 全面记叙植被的群落外貌、种 类组成、群落结构和功能以及地理分布和环境条件 等特征, 并对同类植被进行归纳和总结的志书” (方 精云等, 2020)。《中国植被志》是第一部全面、系 统、准确反映中国植被现状的大型系列志书, 预计 包括48卷110册。《中国植被志》拟在整编历史调查
资料的基础上，通过大量野外群落调查，采用统一 的规范, 量化记载并系统总结中国植被类型及其基 本特征, 为全面掌握中国植被的本底状况提供完整 的科学资料。

植被类型的多样性及植被的复杂程度与气候条 件, 特别是水分和热量等密切相关, 也取决于地表 环境的异质性、地质历史以及外界干扰等因素, 表 现为植被的外貌、结构、物种组成、动态、功能以 
及地理分布等方面的巨大变化。植被类型的划分通 常遵循由远及近、由表及里的原则。具体来讲, 植 被高级分类单位的划分主要基于植被的外貌和自然 环境; 植被中级和低级分类单位的划分主要基于群 落的结构和物种组成(中国植被编辑委员会, 1980;

Federal Geographic Data Committee, 2008; 宋永昌 等, 2017)。这种自上而下等级式的植被分类框架， 隐含着植被分类单元的环境幅度由宽到窄的变化序 列, 反映了植被类型的分化与环境条件之间的密切 关联, 即有什么样的生境就有什么样的植被, 而不 同植被或者植物群落也可反映特定的生境类型。《中 国植被》(中国植被编辑委员会, 1980)对中国植被高 级和中级分类单位的基本特征及其环境背景进行了 概述, 揭示了中国植被类型多样性和生态地理分布 的总体格局。《中国植被志》研编的对象包括中国植 被分类系统的高、中、低级 3 个基本的分类单位，即 植被型、群系和群丛(方精云等, 2020; 郭柯等, 2020)。其中, 植被高级分类单位的描述是在中国植 被分类系统中级和低级分类单位描述的基础上, 对 《中国植被》(1980)相关内容进行修订和拓展, 对中 国植被基本特征提供客观和准确的记述。中国植被 分类系统的中级和低级单元的系统分类和量化描述 是《中国植被志》研编的重点内容, 将编制出中国 植被的首个群丛名录, 基本摸清中国植被的本底, 并为中国植被分类系统的修订、高级分类单位基本 特征的描述和归纳提供实证资料。

《中国植被志》主要以中国植被分类系统的高 级分类单位“植被型”为单位分卷, 以“植被类型”为 单位分册; “植被类型”在此特指具有相同的建群种 或相同的优势类群(如种、属), 分布在一定生境条件 下所有植物群落的总称, 其划分方法须遵循优势类 群及生活型的同一性, 生境条件的相对重要性, 植 被特征及用途的差异性和植被志的应用性等原则 (方精云等, 2020)。在《中国植被志》的每一册中, 通 常以群系为单位进行分章描述(根据植被类型的复 杂程度也可采用较高级的分类单位分章)。在一个群 系内, 遵循上述基本原则并基于群落结构和物种组 成的差异, 可进一步划分出不同的群从组和群从。 因此, 《中国植被志》的每一册是在对植被地理分 布、环境背景和植被类型进行描述的基础上, 基于 样方数据的分析结果, 对群从组和群从进行系统的 分类与描述, 主要回答“有什么类型, 具备怎样的特
征, 在哪里分布, 生长状况怎样, 资源现状如何”等 问题。具体来讲, 每一个群系描述的内容包括地理 分布、自然环境、生态特征、物种组成、群落结构、 群从组和群从的分类与描述, 优势种的生物学特性, 生物量与生产力, 植被动态与演替, 价值与保育等。 为了兼顾研编工作的深度和广度, 根据相关研究成 果积累的程度, 在上述各部分中设定了规定内容和 自选内容。规定内容将确保重点描述内容的规范性、 完整性和一致性, 自选内容旨在体现《中国植被志》 的开放性、集成性和百科全书的风格, 研编工作力求 规范, 但保持包容与开放, 以反映最新的研究成果。

《中国植被志》的研编是中国植被研究中的一 项全新工作, 由文献整编、群落调查、数据分析与 整理、文本撰写等环节组成。为了实现植被描述系 统化、规范化和数量化的科学目标, 在研编内容与 规范的编制过程中, 充分吸收了中国植被基础研究 的重要成果(中国植被编辑委员会, 1980; 中国科学 院中国植被图编辑委员会, 2007a, 2007b), 同时借 鉴了国际植被分类与描述的相关标准(Rodwell et al., 1991; Weber et al., 2000; Jennings et al., 2009; FaberLangendoen et al., 2014)。近年来多次组织专家对规 范草案进行讨论和完善, 在植被志的描述大纲及拓 展内容, 群系组和群系、群从组和群丛的分类方法, 植被分类单元的命名和编码规范，植被的描述规范 等方面进行了创新发展; 先期开展的对中国云杉林 群系组(Picea Forest Alliance Group)的研编试点工 作(王国宏, 2017)对规范的完整性、学术高度和适用 性等进行了研编示范, 使原则性和纲领性的规范进 一步具体化。因此, 本文提出的方法和规范是一个 可操作的植被志研编指南, 主要内容包括植物群落 调查的内容与规范及历史样方数据的整理规范, 文 献收集与整编规范，气候、土壤、地形等相关数据 来源及其整理规范，植被分类方法与规范，植被命 名规范, 植被分类单元描述的内容与规范, 植被志 章节编写大纲、体裁及撰写规范等。虽然本规范仍 然存在改进和完善的空间, 但是在《中国植被志》 未来的研编过程中, 它将与《〈中国植被志〉的植被 分类系统、植被类型划分及编排体系》(方精云等, 2020)和《中国植被分类系统修订方案》(郭柯等, 2020)共同构成《中国植被志》研编的3个初步的纲 领性文件, 为中国植被的分类与描述由定性概述提 升到定量描述提供方法论。 


\section{1 植物群落调查的内容与规范及历史样方 数据的整理规范}

植物群落调查是植被志研编的最基础、最核心 的工作; 植物群落样方资料是植被分类和植被特征 记述的基础, 是植被志的主要支撑数据。发达国家 都十分重视按照统一的技术规范进行植被调查, 在 此基础上进行植被志的研编（方精云等，2009, 2020)。中国植被的基础性工作虽然取得了很大的成 就, 但多缺乏基于大量规范样方资料的数量分析, 植被分类偏重经验, 群落特征的描述以定性为主, 植被志书的科学性和应用性等方面亟待提升。

中国自 20 世纪 50 年代以来进行了大量的植被调 查工作, 积累了丰富的样方数据资料。由于样方调 查的年代差异悬殊, 调查方法和内容各异, 样方数 据的质量参差不齐、可比性低; 样方的空间布局也 极不平衡，一些地形复杂的偏远山区以及环境恶劣 区域的植物群落调查工作尚属空白。可见, 无论是 样方数量还是样方质量, 历史样方数据都远不能满 足《中国植被志》对植被描述系统化、规范化和数 量化的总体要求。因此, 作为《中国植被志》研编 的主要数据支撑, 植物群落的样方数据应主要来自 基于统一技术规范的全面、系统的植被清查工作。

\section{1 群落清查中的重要概念}

关于“样地”“样方”“样格”的定义：在本文中, 样地(site)指群落调查的所在地, 在空间上它包含样 方, 一般没有特定的面积; 样方(plot)是指群落调查 所要实施的特定地段, 有特定的面积。例如, 森林调 查的样方面积一般为 $600 \mathrm{~m}^{2}$ 或 $1000 \mathrm{~m}^{2}$, 由几个 $10 \mathrm{~m} \times 10 \mathrm{~m}$ 的小样方组成, 这种小样方常称作样格 (quadrate)。样方面积有大有小, 但一个样格的面积 是固定不变的。例如, 森林调查中的样格特指 $10 \mathrm{~m} \times 10 \mathrm{~m}$ 的小样方。群落调查中的其他重要概念 和测度方法详见《植物群落清查的主要内容、方法 和技术规范》(方精云等, 2009)。

\section{2 样地的布设原则}

群落调查中的样地布局需遵循全面性、代表性、 典型性和可操作性的原则。全面性指样点应覆盖特 定植被类型的整个分布区域，在空间上布局合理， 能够反映分布区内植被和环境的全貌; 代表性指布 点必须包含分布区内有代表性的植物群落类型，除 了水平和垂直地带性的植被类型外，还应包括不同
植被演替阶段或特殊生境下的群落类型; 典型性指 布点时应覆盖研究区内的典型植被类型, 对于有特 殊生态、经济或科学价值的群落类型, 如特有、稀 有、濒危的植物群落, 也要重点调查; 可操作性是 指调查工作量的设定要充分考虑安全性、人员配备、 技术支持及后勤等因素，确保样点布设方案及野外 调查工作能够顺利实施。

根据《中国植被志》的卷册编排体系(方精云等, 2020), 需要对每册所涉及的植被类型的群落调查 方案进行规划和布局。在文献调研的基础上，根据 1:100万中国植被图等植被图件，以及全国和地方 性的植被志书、科考报告、论文和历史样方等资料, 确定样地布设的大致位置，确保对全国同类植被类 型的全覆盖。在景观尺度上, 还要沿海拔梯度设置 样地。

\section{3 群落清查的内容与方法}

\subsection{1 群落调查表}

群落调查表是在野外现场对群落开展调查工作, 包括踏查、样方设置、观测、采样和拍照等环节所 获得的原始数据进行详细记录的表格。设计合理可 行的群落调查表是确保群落清查规范性和完整性的 重要保障(方精云等, 2009)。植物群落调查表(附表1) 包括样方基本信息记录表(附表1-1)和群落分层记录 表(附表1-2、附表1-3、附表1-4)，引自方精云等(2009)， 有修改。样方基本信息记录表的上半部分为各植被 类型的通用信息，下半部分包括了森林群落的特有 信息。用于其他植被类型的调查表可在此基础上删 减或增加调查内容。例如，农业植被(栽培植被)的调 查表中需要增加土壤种子库的调查内容。调查表中 各项具体调查规范详见表后说明。群落调查表中也 留出了绘制群落剖面图(示例见图1)的位置, 在群落 调查中对群落剖面图的绘制要给予足够的重视。

群落的垂直剖面图在群落调查的现场绘制。通 常由样方的一个边长向样方内推移一定的距离而形 成一个群落窄带, 该边长即为窄带的长边; 窄带短 边的长度视群落的密度而定: 森林群落的窄带短边 一般不小于 $3 \mathrm{~m}$, 灌丛群落不小于 $1 \mathrm{~m}$, 草本植被群 落不小于 $10 \mathrm{~cm}$ 。剖面图是这个窄带中各个物种在一 个与窄带长边等宽、高度略大于群落中最大个体高 度的垂直平面上的投影, 可反映出一个群落的垂直 分层结构和物种组成特征。通常用简明的线条勾绘 出不同的形状，以表征群落各层的优势种和一些常 


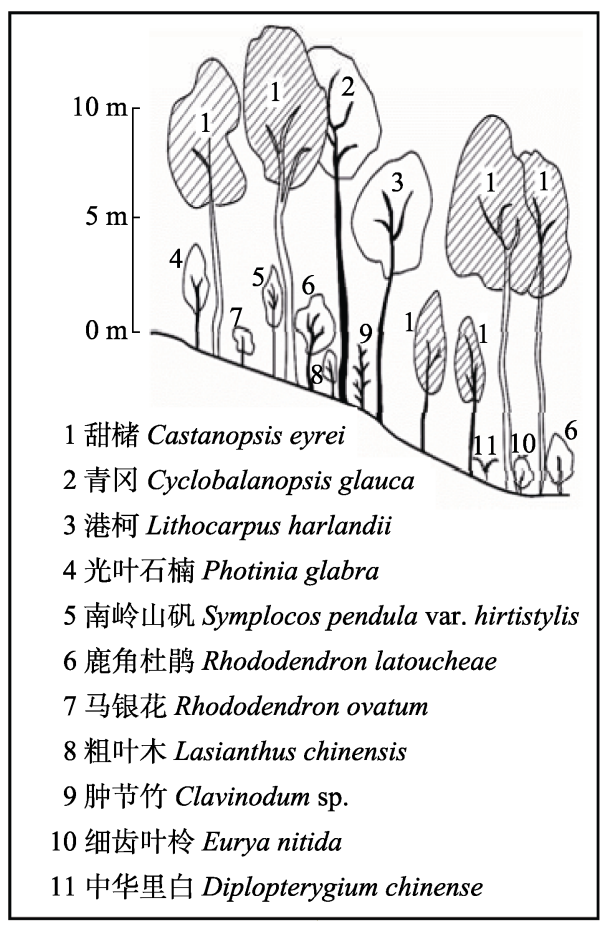

图1一个森林植物群落的剖面图(引自《福建植被》(林鹏, 1990), 有修改)。

Fig. 1 Illustration of vertical structure of a forest community (modified from Fujian Vegetation (Lin, 1990)).

见的伴生种的外貌特征。通过在图中添加比例尺, 可显示出各物种的个体高度与样方边长的比例关系, 以反映群落的实际状况。图中的物种用数字标注, 在图中留白处顺序列出数字所对应的植物名称(如 图1)。现场难以定名的植物, 经后续鉴定后在调查 表中予以修改或补充。

\subsection{2 样地选择与样方设置}

在样地选择过程中, 首先需进行踏查, 掌握群 落的空间散布特点, 在此基础上选择具有代表性的 群落设置样方。每个样地设置3-5个样方作为重复, 重复样方之间需有足够的间距。根据植被类型的复 杂程度或群落斑块的大小, 重复样方的数量可适当 增减。

样方的选择应遵循以下原则：首先，除依赖于 特定生境的群落外, 一般选择平(台)地或相对均一 的坡面设置样地, 要尽可能避开坡顶、沟谷、道路、 溪(河)流或其他破碎地形; 其次, 群落内部的物种 组成、群落结构和生境要相对一致, 即不能跨群落 或生境设置样方; 第三, 群落的面积要足够大, 样 方四周要有足够宽度的缓冲区。对于森林群落, 缓 冲区宽度应在 1 个树高以上, 其他植被类型的缓冲 区宽度一般在 $10 \mathrm{~m}$ 以上。中国植被经历的人类活动
干扰较重, 植被片断化现象突出。对于生长在特定 生境中的小群落斑块, 特别是森林群落, 如果其具 有表征特定群落类型的价值，其覆盖面积虽不足以 布设一个正规的样方, 也要尽可能进行调查, 并对 其群落环境进行特别说明。

森林调查样方的大小为 600 或 $1000 \mathrm{~m}^{2}$, 寒温带 至暖温带森林(含垂直植被带)可采用600 $\mathrm{m}^{2}$; 亚热 带、热带森林所需最小取样面积较大，建议采用 $1000 \mathrm{~m}^{2}$, 在地形复杂或群落结构相对简单的情况 下, 样方面积可稍小, 但一般不小于 $600 \mathrm{~m}^{2}$ 。需要复 查的固定样地面积统一采用 $1000 \mathrm{~m}^{2}$ 。经济林、竹 林等可根据具体情况，选择合适的样方面积。

森林样方一般布设为 $20 \mathrm{~m} \times 30 \mathrm{~m}$ 或 $20 \mathrm{~m} \times 50$ $\mathrm{m}$ 的长方形, 由6 (或 10$)$ 个 $10 \mathrm{~m} \times 10 \mathrm{~m}$ 相邻接的样 格组成(图2); 如果群落斑块的形状或地形因素不允 许，也可设置为其他形状。

灌从、草地(含沼泽)样方面积一般为 $100 \mathrm{~m}^{2}$, 周 围应留有 $10 \mathrm{~m}$ 以上的缓冲区。灌从样方划分为 4 个 $5 \mathrm{~m} \times 5 \mathrm{~m}$ 的调查小样方, 在样方四角和中心各设置 $1 \mathrm{~m} \times 1 \mathrm{~m}$ 的草本调查小样方 1 个(图3)。草地(含沼泽) 样方中需调查 5 个 $1 \mathrm{~m} \times 1 \mathrm{~m}$ 的小样方, 小样方的设 置方法参照灌从草本层的小样方。荒漠植被稀疏且 异质性大, 调查面积可视具体情况大于灌从和草地。

农业植被(栽培植被)中的农田作物/杂草以田块 为单位, 每样点选择生境条件基本一致的10块田块 作为样地, 每个田块之间要有一定间隔距离, 田块

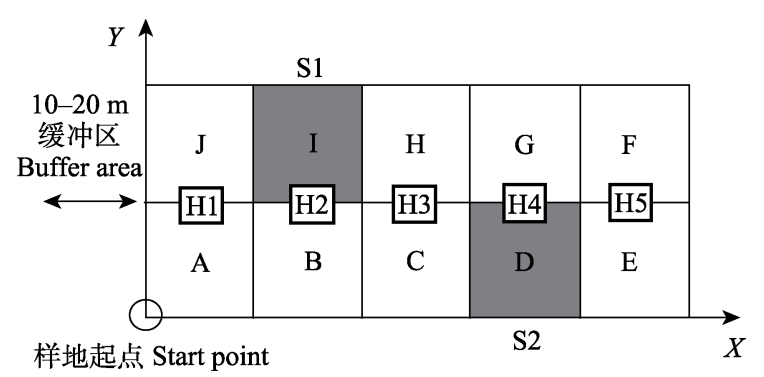

图2 森林群落样方的设置和样格编号方法, 以 $20 \mathrm{~m} \times 50 \mathrm{~m}$ 样方为例, 每个样方由 10 个 $10 \mathrm{~m} \times 10 \mathrm{~m}$ 的样格组成, A-J为 样格编号, $\mathrm{S} 1$ 和 $\mathrm{S} 2$ (阴影部分)为灌木层调查样格; H1-H5为 草本层调查小样方 $(1 \mathrm{~m} \times 1 \mathrm{~m})$ 。样方四边应各留10-20 m的 缓冲区(方精云等, 2009, 有修改)。

Fig. 2 Plot setting and quadrate coding for forest communities. The $20 \mathrm{~m} \times 50 \mathrm{~m}$ plot is composed of 10 quadrates (A-J), each with an area of $10 \mathrm{~m} \times 10 \mathrm{~m}$. The shadowed quadrates (S1 and S2) are selected for shrub layer investigation, and subplots $(\mathrm{H} 1-\mathrm{H} 5,1 \mathrm{~m} \times 1 \mathrm{~m})$ are selected for herbaceous layer investigation. A buffer zone of $10-20 \mathrm{~m}$ at each side of the plot is necessary to keep the plot away from apparent human activities. Modified from Fang et al. (2009). 
的大小以及田块间的距离视具体情况而定。在每田 块内, 沿田块长边按照“W”形连线在顶点和中点各 设置面积为 $1 \mathrm{~m} \times 1 \mathrm{~m}$ 的样方, 共9个样方(H1-H9), 位于“W”顶点处的样方与田块边缘之间要有 $1 \mathrm{~m}$ 以 上的距离(图4)。土壤种子库调查时, 要在每个样方 的四角和中心各设置 1 个直径 $5 \mathrm{~cm}$ 的小样方(图4, P1-P5), 土壤种子库取样深度为 $15 \mathrm{~cm}$, 分 0-5、

5-10、10-15 cm 3个土层。

\subsection{3 群落调查}

群落调查对象确定后, 首先要进行群落基本信

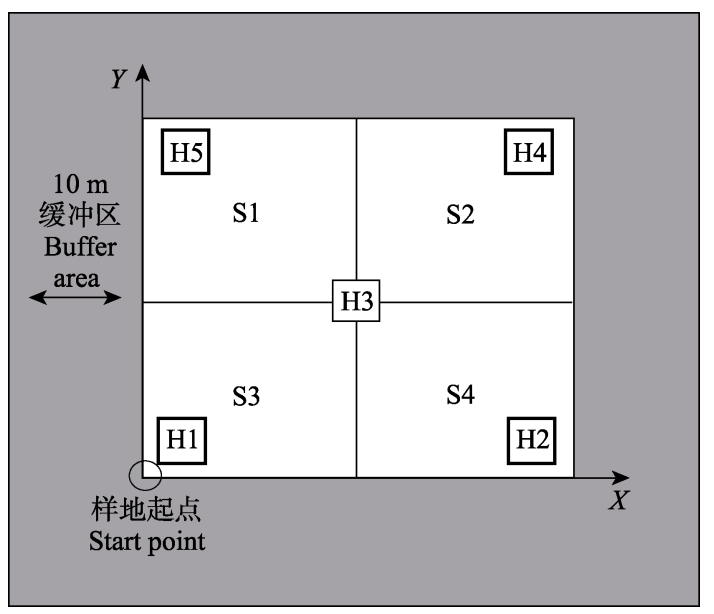

图3 灌丛(草地)样方设置方法, 样方面积 $10 \mathrm{~m} \times 10 \mathrm{~m}$ 。对于 灌丛, 需要调查整个样方(划分为 4 个 $5 \mathrm{~m} \times 5 \mathrm{~m}$ 小样方: S1-S4); 对于草地, 一般只需调查 5 个小样方(H1-H5, $1 \mathrm{~m} \times$ $1 \mathrm{~m})$ 。为避免人类活动干扰, 样地四周一般要留有 $10 \mathrm{~m}$ 宽的 缓冲区(方精云等, 2009)。

Fig. 3 Plot setting of shrub (grassland) communities (10 $\mathrm{m} \times$ $10 \mathrm{~m}$ ). Four subplots $(\mathrm{S} 1-\mathrm{S} 4,5 \mathrm{~m} \times 5 \mathrm{~m})$ for shrub layer and five subplots for herb layer $(\mathrm{H} 1-\mathrm{H} 5,1 \mathrm{~m} \times 1 \mathrm{~m})$ are selected for investigation within each $10 \mathrm{~m} \times 10 \mathrm{~m}$ plot. A buffer zone of 10 $\mathrm{m}$ at each side of the plot is necessary to keep the plot away from apparent human activities (Fang et al., 2009).

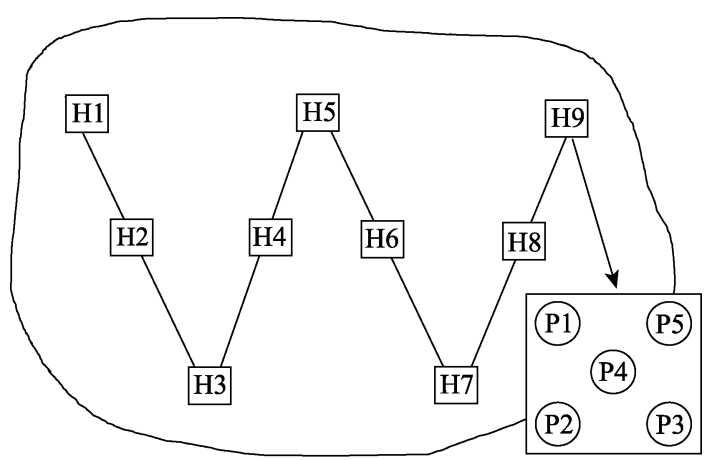

图4 农业植被样方在一个田块中的设置方法。H1-H9为农 业植被调查样方, P1-P5为种子库调查土样采取点。

Fig. 4 Plot setting of agricultural vegetation (H1-H9) and soil seed pool (P1-P5) on a field patch.
息调查。调查的内容包括植被类型、样地所处的行 政区域、地理坐标、地形地貌因子(坡度、坡向、坡 位)、干扰程度、演替阶段、土壤因子(类型及质地) 及排水状况、群落的外貌特征(如季相、色泽、形态)、 群落各层的高度、总盖度和优势种, 并现场绘制群 落剖面图, 完成附表1-1的填写, 具体填写细则详见 附表1-1后的“表格填写说明”。填表过程中, 若出现 与勾选内容不符的选项, 可在空白处或备注一栏中 补充。群落基本信息调查完成后, 即可进行群落结 构和组成等内容的详细调查。

森林群落的调查包括乔木层、灌木层、草本层 和地被层。各层的具体调查内容如下:

(1)乔木层(附表1-2): 记录样方内出现的全部乔 木种, 对胸径 $\geqslant 3 \mathrm{~cm}$ 的个体每木检尺, 测量胸径和 高度, 记录其存活状态。胸径测量中要注意如下几 点: 生长在坡面上的个体, 从上方测; 倾斜的个体 从下方测; 树干表面附有藤蔓、绞杀植物和苔藓等, 需去除后再测定; 胸高以下分枝的茎干, 要分别进 行测量; 具有板根或粗大节的树干，要在板根或树 节上方的适当位置进行测量(方精云等, 2009)。树高 不仅对于测定林分的生物量和生产潜力十分关键, 对于确定各树种在群落中的地位和生态功能也有重 要的意义。以往由于仪器的限制, 树高测定比较困 难, 在群落调查中树高测定往往被忽略。近年来逐 渐普及的超声波测高仪, 测定精确度高, 速度快, 在坡度校正处理上也很方便，建议在今后群落调查 中对树高的测量给予足够重视。乔木层测定的技术 细节详见附表1-2的说明。

(2)灌木层(附表1-3): 选取样方对角的两个样格 (图2), 对灌木层进行详细调查。分种记录基径、平 均高度、冠幅、株从数和盖度等。测量个体包括灌 木种和乔木更新幼苗、幼树。此后, 还需在样方中 的其他样格里进行踏查, 记录在上两个样格中未出 现的灌木种(包括更新幼树)和样格号。这一步骤是 为了测定整个 600 或 $1000 \mathrm{~m}^{2}$ 样方的物种数, 不能 忽略。

(3)草本层(附表1-4): 在样方中均匀布设 5 个 $1 \mathrm{~m} \times$ $1 \mathrm{~m}$ 的小样方(或在样方四角和中心梅花点取样), 小 样方编号方式见图2或方精云等(2009)文中的图4。 在每个草本小样方内, 记录所有草本层植物的种 名、多度、平均高度、盖度和小样方的总盖度。由 于物种个体大小差异较大, 株数的意义不大, 统一 
按照表格下的德氏多度等级记录多度。

此后, 同样需要对样方中的剩余部分, 逐样格 仔细搜寻在草本小样方中未出现的物种, 记录样格 号和物种名。

(4)地被层(附表1-4): 样方布设方式同草本层。 在每个小样方内, 记录苔藓、地衣、藻类和菌类的 种名、平均高度、盖度和多度等级等。

层间植物由寄生、附生植物和攀援植物等组成。 群落调查中要估计其所处的高度、多度和盖度。在 群落各层的物种统计中, 层间植物要统计为所在群 落层的物种。

(5)土壤调查: 条件允许时, 要进行土壤调查。 在样方附近挖 1 个土壤剖面记录土壤剖面特征; 以 $100 \mathrm{~cm}^{3}$ 的土壤环刀，按0-10、10-20、20-30、30-50、 50-70、70-100 $\mathrm{cm}$ 的土壤深度分层取样, 称取鲜质 量并编号, 用于实验室理化性质分析。用于样方土 壤理化性质总体特征分析的调查工作, 一般需取 $3-5$ 个点的混合土样。

(6)群落照片: 群落照片是《中国植被志》研编 必需的基础资料, 每个样方都需要拍摄群落外貌、 群落垂直结构、乔木层、灌木层、草本层、地被层、 各层优势种及土壤剖面的照片。数码照片的分辨率 应在1 200万像素以上, 并记录照片的经纬度等信息。

灌从(含荒漠)、草地(含沼泽)的群落调查方法与 森林群落中的灌木层和草本层的调查方法类似。对 于灌从(包括草地群落中的灌木), 需要调查整个样 方 $(10 \mathrm{~m} \times 10 \mathrm{~m})$, 划分为 4 个 $5 \mathrm{~m} \times 5 \mathrm{~m}$ 的小样方; 对 于草地, 详细调查 5 个 $1 \mathrm{~m} \times 1 \mathrm{~m}$ 的草本小样方。

水生、农田等群落的调查较为特殊(强胜, 2011)。农业植被需要增加土壤种子库的调查内容, 土壤种子库取样调查每块农田设计 45 个取样点(图 4)。具体调查方法和实施方案参见文献(Bigwood \& Inouye, 1988; Thompson et al., 1997; 马波等, 2004)。 群落调查一般在植物的生长旺季进行。虽然理想情 况下应在生长季不同阶段对群落进行多次调查, 但

《中国植被志》群落调查工作量巨大, 多数样地只 能进行一次调查, 这种情况下应避免在生长季的初 期和晚期进行调查。农业植被尤其是农田作物植被 的季相变化快, 调查一般在作物花果期为宜。

\section{4 历史样方数据的整理规范}

历史样方数据是指来自文献记载、专业数据库 收录、单位或个人收藏的样方数据, 是《中国植被
志》样方数据的一个必要补充, 需要系统收集、整 理和甄别, 以便参考和利用。历史样方根据调查方 法的规范性、数据内容的完整性等可分为 3 类: 一级 样方, 即完全或基本符合《中国植被志》群落调查 规范的样方, 这些样方数据可按相关规范整理入附 件中的相应表格中, 用于统一的数据分析。二级样 方, 指样方的面积基本符合规范或具有合理性, 地 理坐标、地形地貌、坡度、坡向、坡位、干扰状况 等信息基本完整，物种正确鉴定到种的比例达到 $80 \%$ 以上，群落及各物种的重要数量信息基本完整， 这些信息包括各层的总盖度, 乔木的胸径和高度 (每木检尺), 其他生活型植物的分种盖度、多度及高 度等, 并附有反映群落外貌、结构和优势种的照片, 这类样方可用于植被分类与描述。三级样方, 缺乏 地理坐标, 地形地貌等因子的记载不完整, 物种鉴 定的准确率较低, 群落及各物种的重要数量特征缺 失; 这类样方一般不作为植被分类、命名和描述的 凭证，但可作为植被志研编的参考资料。

一个植被类型在自然界有一定的地理分布范围, 占据着一定的生境类型, 经受自然或人类活动的影 响, 群落的外貌、结构和组成也具有动态的特征。 《中国植被志》中所引证的样方是针对植物群落的 一个调查单元，样方信息要反映这个群落的基本特 征。由于植物群落内部结构的变异性, 通常规定一 个森林群落的基本特征由若干个具体的群落样方来 共同表达。作为植被志描述的基础数据，样方资料 一般要满足几项基本条件。首先, 样方的调查方法、 内容以及数据的完整程度要符合上述规范。其次, 样方的空间布局一般要覆盖一个植被类型的全部地 理分布范围和生境类型, 这些样方在空间分布上要 具有一定的均匀性, 对主要生境类型要有一定的代 表性。具体而言, 在特定植被类型分布范围内的行 政区域(如一个县)内, 调查的样方一般不少于 3 个, 每个群丛的凭证样方一般不少于 5 个, 特殊植被类 型, 如地理分布狭窄或群落斑块面积较小的类型可 酌情例外。这里所涉及的植被类型一般指群系及其 以上的植被分类单元，包括在《中国植被》(中国植 被编辑委员会, 1980)和《中国植被及其地理格局 一一华人民共和国植被图(1:1000 000)说明书》 (中国科学院中国植被图编辑委员会, 2007b)等重要 文献中已经记载的类型以及在植被志研编过程中新 发现的类型。第三，要尽可能获得同一个植被类型 
的重复调查资料, 以反映植被的动态特征。样方指 标是植被志书稿审理工作中的一项重要内容, 植被 类型的凭证样方、群落照片、物种鉴定凭证(标本、 照片)、原始记录扫描文件、文献信息等要与植被志 书稿同步提交并建立统一的数据库。

\section{2 文献收集与整编规范}

《中国植被志》的基本定位是一套研究型的学 术专著。因此, 在研编过程中, 首先通过对文献的收 集与整编, 建立植被志历史文献数据库; 在此基础 上, 系统梳理和总结国内外植被研究的科学成就, 确定志书研编工作的经纬, 并收集包括样方在内的 植被数据资料。因此, 文献收集与整编是植被志研 编工作的重要环节。

植被志历史文献数据库旨在全面收集国内外公 开发表的相关文献资料, 包括各类专业出版社收录 的文献、网络资料和其他各类纸质文献等。历史文 献可划分为通用文献和专用文献两大类。通用文献 包括各类工具书、植被志书、植被综合研究报告等, 可根据文献的类型编排入库; 专用文献是针对特定 植被类型的研究资料, 包括综述、研究报告、资料 论文等, 通常根据所属的植被分类单位由高级到低 级逐次进行编排、归类、入库。以基于Endnote建立 的文献数据库为例, 如果以植被型或植被型组为单 位建立总文献库, 其下可进一步根据植被中级、低 级分类单位(群系组、群系、群从组、群从等)建立 若干子库; 每一篇文献包括了作者、出版年代、题 目、出版物类型、出版物名称、关键词、摘要和全 文链接或全文附件等信息。这种自上而下、逐级深 入的检索框架体系, 可快速准确地存咜和检索数 据。文献数据库是一个开放式的文献管理平台, 可 方便地进行文献的更新、补充、编排、归类、存咜 和引用。在植被志研编中, 植被志的每一卷册需要 建立各自的文献数据库, 研编工作完成后要统一汇 交至“中国植被综合数据库”。从文献数据库中调取 的文献可直接阅读和引用。如果同类文献数量较多, 结构复杂, 还需要进行二次整编。

在建立文献数据库的基础上, 通过文献的整理 分析, 全面集成植被科学领域的研究成就。在成果 类历史文献整编中, 重点对植被地理分布、自然环 境、生态特征、植被分类与描述、优势种的生物学 特性、生物量与生产力、植被动态与演替, 以及价
值与保育等方面的研究成果进行整理汇总, 包括对 文字描述和图表等内容的摘编和收录。植被文献的 整编过程不作具体要求, 可利用文献数据库中相关 功能直接检索、阅读和引用。需要强调的是, 植被 类型名称的考订和描述的修订是植被志研编工作中 的一项重要内容。在相关文献整编中, 要以植被志 的一个卷册为单元, 将文献中出现的相关植被类型 的中文名称(包括全称和简称、俗名)、科学名称、 文献来源(包括出版物的名称、年代、卷期、页码等) 等进行系统录入整理, 并提供原始描述的链接或全 文。一个植被类型在不同的文献中可能被冠以不同 名称, 对涉及的相关文献要逐一进行整编和录入。 特别注意, 对历史文献中的资料在引用时切忌一成 不变地复制, 文献整编中要对前人资料进行分析, 形成自己的学术观点, 力求超越前人对资料的理解 和分析水平。如果确实需要完全引证前人研究成果 原文信息，文字要采用全引的方式，即用双引号， 并注明原著者的信息; 对于根据原始文献改写的部 分、引用的图表等要注明文献出处, 文末列出全部 参考文献。

文献整编的另一个重要目的就是获取包括样方 数据在内的资料数据。在原始数据文献的整理中, 各类原始数据要忠实录入, 系统编码, 分类存档, 通常使用Excel和Access等软件进行数据的存咜、管 理和分析。植被文献中的各类原始数据包括样方数 据、树干解析数据、植物生理生态观测数据、环境 因子的测试数据、植物或群落的图片资料等。每一 类原始数据, 为了便于管理和使用, 可根据数据结 构进行下一级的划分。以“样方数据”这个数据类型 为例, 其下可进一步分为基本信息、乔木层、灌木 层、草本层和地被层等数据类型; 在基本信息中, 以样方为单元进行存咜，每个单元包括样方编号、 植被类型、地理坐标、地形地貌、干扰类型、调查 者、调查日期、数据来源等字节。原始数据录入存 档以后, 要通过研读原始文献中数据的采集方法、 数据结构分析, 必要时咨询文献作者或数据采集者, 对原始数据的可靠性和质量进行评估, 供使用时参 考。对于经过核实拟采用的文献原始数据, 要忠实 引用, 切忌随意篡改。在引证过程中, 除了遵循文献 引用的一般规范外, 还应特别体现出原始数据采集 者的贡献。例如, 对于样方数据, 应注明样方的调查 者; 对于图片资料，应注明照片的拍摄者。文献中 
的原始数据在直接引证或再分析的过程中, 应注明 新编码与文献中原始编号的对照关系, 以便追溯。

\section{3 气候、土壤、地形等相关数据来源与规范}

气候、土壤、地形地貌等信息是《中国植被志》 研编中各植被类型环境背景描述的重要依据, 所凭 证数据资料主要来自相关专业领域中的权威专著、 专业数据库和样方数据等。

一个植被类型所在区域的气候、土壤、地形地 貌的描述包括定性和定量两个方面。定性描述是对 一个植被类型大尺度环境背景基本特征的描述和铺 垫。气候带、土壤类型和地貌类型的划分方案、术 语名称、各类型基本特征的描述要采用相关专业领 域权威专著或研究成果中发布的标准。相关的权威 研究专著包括《中国自然地理》气候、土壤和地貌 分册(《中国自然地理》编辑委员会, 1980, 1981, 1984), 以及后续出版的中国自然地理系列专著: 《中国气候》(丁一汇, 2013), 《中国地貌》(尤联元 和杨景春, 2013), 《中国土壤地理》(龚子同等, 2014) 等。在局地尺度上, 一个植物群落所在生境的地形 地貌和土壤类型的定性描述主要基于样方资料。

环境背景定量描述的依据主要来自专业数据库 中发布的数据、相关文献以及样方调查中的实测资 料。就气候数据而言, 通常利用样方的地理坐标, 从 专业气候数据库中提取对应的气候数据, 实现对植 被类型气候特征量化描述的目标。在一个植被类型 的分布区内, 样方的地理坐标是利用GPS现场测 得。对于样方空缺的植被区域, 或没有标定地理坐 标的样方分布区, 在 $0.5^{\circ} \times 0.5^{\circ}$ 的经纬度方格内至 少要有一个样点, 样点的地理坐标可以利用数字地 球系统(如Google Earth), 结合样方地理位置的描述, 以及卫星影像判读等方法获取; 样方海拔主要利用 实测设备测量或根据地理坐标利用美国地质调查局 (USGS)的数字高程模型(DEM)获取(https://lta.cr.usgs. gov/GTOPO30)。需要呈现的气候因子包括年平均气 温、最冷月平均气温、最热月平均气温、年降水量、 潜在蒸散、实际蒸散、湿润指数(实际蒸散/潜在蒸 散)等(附表2)。基于样方地理坐标的气候数据由《中 国植被志》研编办公室统一提供。

土壤类型、典型土壤剖面描述及分层土壤理化 性质的相关数据可以引自土壤数据库、文献以及基 于样方调查的土壤样品实测结果。中国土壤数据库 (http://vdb3.soil.csdb.cn) 提供了全国范围的典型剖 面的地理位置, 土壤类型, 剖面类型, 剖面层次, 分 层土壤物理性质(厚度、容重、质地、机械组成), 土 壤有机质, 土壤全氮、全磷, $\mathrm{pH}$ 和 $\mathrm{CaCO}_{3}$ 等信息。在 一些专业文献中, 例如《中国森林土壤》(中国林业 科学研究院林业研究所, 1986), 也记载了大量的典 型土壤剖面数据。在引用文献中的土壤剖面数据前, 要核对土壤剖面所在的植被类型与拟描述植被类型 的相关性或一致性。如果二者的相关性较低, 其土 壤剖面数据一般不宜采用。在植被样方调查中获得 的土壤剖面数据, 应优先使用。

\section{4 植被分类方法与规范}

\section{1 总则}

这个方案主要针对中国植被分类系统中级和低 级单位, 即群系组、群系、群丛组和群从的分类。

中国植被分类系统修订方案(郭柯等, 2020)(以 下简称“修订方案”) 在《中国植被》(中国植被编辑 委员会，1980)(以下简称“80方案”)的基础上，提出 了中国植被分类系统中级和低级分类单位划分的基 本原则, 即: 群系组是“中级主要分类单位之上的辅 助分类单位。在同一个植被型或亚型范围内, 建群 种为同属植物的植物群落, 和多个植物种经常形成 共优势组合的植物群落联合即为群系组”。群系是 “建群种或主要共建种相同的植物群落联合”。亚群 系是“中级主要分类单位之下的辅助分类单位。建群 种生态幅度较广的群系, 由于分布生境的不同, 群 落的其他优势种和种类组成也可能存在明显的差 异。这时, 可以根据群落生境的综合特征和建群种 之外其他优势植物生活型以及生态习性等进一步划 分亚群系。对于绝大部分群系来说, 不需要再划分 亚群系”。群丛组是“凡是层片结构相似, 且优势层 片和次优势层片的优势种或共优种(或标志种)相同 的植物群落联合即为群从组; 对于层次结构较简单 的植被类型, 次优势层或层片的优势植物生活型和 生态习性相同的植物群落联合即为群从组”。群丛是 “凡是物种组成基本相同，且层片结构和各层片的 优势种或共优种(或标志种)相同, 群落结构和动态 特征(包括相同的季相变化规律和演替阶段等)以及 生境相对一致, 具有相似生产力的植物群落联合”。 上述基本原则事实上确立了一个以建群种、优势种 或共优种(或标志种), 群落分层结构及其物种组成 
等指标来划分植被类型的总体框架。需要指出, 中 国植被类型复杂, 植被类型的划分还要考虑植被自 身的特殊性, 体现多元化的特点, 才能反映中国植 物种类组成复杂和生境多样的特征(方精云等, 2020)。因此, 在遵循上述植被分类基本原则的基础 上, 需要提出针对中级和低级植被分类单元划分的 具体标准和工作方案。

\subsection{1 植被分类中的一些重要概念}

群落结构和物种组成是植被中级和低级分类单 元划分的主要依据, 一些相关的重要概念简要梳理 如下。

植物群落(plant community): 某一地段内生境 条件相似的植物种类集合。植物群落具有一定外貌、 结构和共存的物种, 物种或个体间存在竞争、互惠 等相互作用，以适应其共同生存的环境(Whittaker, 1978; 宋永昌, 2017; 方精云等, 2020)。植物群落是 植被的基本单位, 植被分类的目的就是对植物群落 分门别类, 划归为不同的植被分类单元(方精云等, 2020)。

生活型(life form): 植物在长期适应环境过程 中所表现出的形态外貌和生活史对策, 是植物趋同 适应的结果(方精云等, 2020)。“80方案”基于植物形 态外貌(例如: 乔木、灌木、草本、叶状体; 针叶、 阔叶、退化叶)和生活史对策(例如: 一年生、多年生; 常绿、落叶)等指标提出了植物生活型划分的五级分 类系统。在《中国植被志》研编中，我们将采用“80 方案” 的植物生活型分类系统进行植被类型的划分 和描述。

生长型(growth form): 植物的形态、外貌和结 构的总称, 是植物生长条件和遗传背景的综合反映 (Federal Geographic Data Committee, 2008)。美国植 被分类系统中常用“生长型”描述植物或植物群落的 外貌特征。在美国植被分类系统“生长型”的划分方 案中，除了没有使用“一年生”和“多年生”对“草本植 物”进行进一步划分外, 其他指标与“80方案”中“生 活型”划分的指标几乎相同(Federal Geographic Data Committee, 2008; Faber-Langendoen et al., 2014)。“一 年生”和“多年生”等生存对策是反映植物生活史特 征的重要指标。从这个意义上讲, 虽然“生长型”的 内涵与 “生活型” 非常接近, 但更加偏重植物的形态 外貌(宋永昌, 2017)。

显然, “生活型”的内涵较“生长型”更加宽泛。
在《中国植被志》研编中, 除非特别说明外, 主要以 “生活型”描述群落的外貌和结构。

层(stratum): 群落中处在特定高度范围内、生 活型相对一致的植物组合, 是反映群落结构的基本 单位(Federal Geographic Data Committee, 2008)。 “层”的名称由层中植物优势生活型(乔木、灌木、草 本等)与“层(stratum)”组合而成。例如, 在森林群落 中, 基于高度 $\geqslant 5 \mathrm{~m} 、 0.5 \mathrm{~m} \leqslant$ 高度 $<5 \mathrm{~m}$ 和高度 $<0.5 \mathrm{~m}$, 可划分出乔木层(tree stratum)、灌木层(shrub stratum) 和草本层(herb stratum)。由于 “层” 是基于植物的高 度和优势生活型划分的, 在一个群落层中就可能包 含多个植物生活型。例如, 在乔木层中, 可能包含高 度超过 $5 \mathrm{~m}$ 的大灌木、木质藤本以及附生和寄生等 生活型的木本植物, 但这些植物并不占优势。此外, 如果群落中包含多个层, 则数量最多、盖度或生物 量最大的层可称为优势层(dominant stratum)。

层片(layer): 群落中生活型相同的植物组合 (中国植被编辑委员会, 1980; Federal Geographic Data Committee, 2008; Jennings et al., 2009), 是群 落垂直或水平尺度上的结构组分和群落结构中的 一个基本单位。

“层片”的英文名称最初使用“synusia” (中国植 被编辑委员会, 1980)。在英美植被分类文献中, 用 于描述群落结构基本单位 “层”的词汇多使用 “stratum”和“layer”, 但二者的含义不同。如前所述, “stratum”主要用于描述基于植物高度所划分出的群 落垂直分层, 而“layer”的用法较为通俗和宽泛, 可 指代任何一个群落层; 在一些文献中则是指由同一 生长型的植物所组成的层(Federal Geographic Data Committee, 2008), 与“层片”的含义较为接近。我们 采用这一用法, “层片”的英文使用“layer”。

群落中的一个层(stratum)中, 可能会包含一个 或几个层片。如果某层中只包含一个层片, 则层 与层片所描述的群落层就完全相同。如果群落中 或特定群落层中包含多个层片, 则数量最多、盖度 或生物量最大的层片可称为优势层片 (dominant layer)。除特别说明外，本文中有关“群落分层”或 “垂直分层” 的提法, 一般是指层(stratum); 由特定 生活型植物所组成的群落结构, 则使用层片(layer) 进行描述。

优势种(dominant species): 特定群落层或层片 中数量最多、盖度最大的物种(中国植被编辑委员会, 
1980), 这些物种也通常具有最大的生物量和营养 空间(Faber-Langendoen et al., 2014)。出现在优势层 或优势层片中的优势种可称为建群种(constructive species); 如果在优势层或优势层片中存在多个优 势种, 这些优势种可称为共建种(co-constructive species)。

在植被分类中, 通常以相对盖度、重要值或优 势度(森林群落) $75 \%$ 作为确定优势种或优势生活型 的阈值。相对盖度(或其他指标, 下同) $\geqslant 75 \%$ 的物 种、群落层或层片可确定为单优势种、单优势层或 单优势层片; 其他物种可称为伴生种。在 $10 \%-75 \%$ 的相对盖度区间内存在多个物种, 以及多个层或层 片, 如果物种间、层或层片间的相对盖度值相差超 过 $10 \%$, 根据相对盖度值由大到小的次序划分出优 势种、优势层或层片, 以及次优势种、次优势层或 层片; 如果物种间、层或层片间的相对盖度值相差 不超过 $10 \%$, 可确定为共优势种、共优势层或层片。 如果单个物种、层或层片的相对盖度不超过 $10 \%$, 这样的群落可确定为优势种、优势层或层片不明显 的类型, 在植被类型的划分、命名或描述过程中可 对相对盖度值进行简单排序, 确定物种、层或层片 名称的选用或描述的优先次序。

常见种(constant species): 在一个植被分类单 元的凭证样方中出现频率较高的物种。在植被分类 运算中, 通常以 $\geqslant 60 \%$ 的频率值作为确定常见种的 阈值。频率 $<60 \%$ 的物种可划归为偶见种(rare species), 即在一个植被类型的凭证样方中出现频率较 低或偶见的物种。

特征种(diagnostic species): 是指对植被类型 划分具有鉴别或区分作用的物种或物种组合。在植 被分类文献中, 用于植被类型划分的物种或物种组 合有多种称谓, 彼此之间的内涵也存在一些差异, 常见的有特征种、标志种(在特定植被类型中出现的 数量明显高于其他类型的物种)和区分种(较严格地 出现在特定植被类型中的物种)等(中国植被编辑委 员会, 1980; 宋永昌, 2013, 2017; 宋永昌等, 2017); 在英文文献中的相关术语有 diagnostic species、 character species 和 differential species 等 (FaberLangendoen et al., 2014)。在 《中国植被志》研编中, 植被类型的划分主要基于对大量样方资料统计分析 所笁选出的一组物种, 按照“80方案”的定义, 此类 物种可称为特征种, 对应的英文名称采用 diagnostic species (Tichy \& Holt, 2006; Faber-Langendoen et al., 2014)。在实际工作中, 通过样方数据的统计分析, 计算出每个物种的特征值 $(\Phi)$, 特征值较高的物种 可确定为特征种。例如, 可选择 $0.25 \leqslant \Phi<0.50$ 和 $\Phi \geqslant 0.50$ 作为划分不同类型特征种的阈值(Tichy \& Holt, 2006)。

\subsection{2 植被中级和低级单位分类方案}

在自然界, 由于环境变化的相对连续性, 同一 个群系不同的群从组之间, 或者同一个群丛组不同 的群从之间, 物种组成不可能存在泾渭分明的界 限。一个常见的现象是, 特定物种组合在一些群落 中出现的概率较高, 而在另一些群落中出现的概率 较低。这些具有生境或群落类型偏好型的物种或物 种组合, 对植被类型的划分具有重要的鉴别意义。 因此，在植被中级和低级分类单位划分中，除了确 定群落的分层特征外, 就是要甄别出特征种。事实 上，特征种也可能同时是一个植被类型的优势种、 常见种、标志种和区分种。以特征种为依据划分群 落类型具有很大的普适性, 因为这个方案不仅规避 了基于优势种进行植被分类的局限性, 也可充分体 现出优势种在植被类型划分中的重要性。

基于以上思考，在遵循中国植被分类“修订方 案”及“80方案”所确立的基本原则的基础上, 需要 对相关原则进行解读, 提出中国植被中级和低级分 类单位中各个分类单元划分的思路、具体标准和实 施细则或工作方案。

群系组(Alliance Group): 一般基于建群种亲 缘关系的相近程度, 例如同属或相近属的植物进行 划分; 此外, 针对一些物种组成复杂、具有共建种 的群系类型, 以及对于灌丛、荒漠和草地等植被类 型, 除了考虑建群种的亲缘关系外, 也可根据生活 型的同一性或生境的相近程度进行划分(中国植被 编辑委员会, 1980)。

群系(Alliance): 主要基于建群种或共建种进行 划分。即, 一个群系内所有植物群落的建群种或共 建种是相同的, 这些建群种同时也是区别于其他群 系的特征种。对于建群种明显的群落, 易于进行群 系尺度上的分类。例如, 雪岭云杉林 (Picea schrenkiana Forest Alliance)和青海云杉林(Picea crassifolia Forest Alliance)是两个不同的群系, 雪岭云杉和 青海云杉分别是这两个群系的建群种, 也是它们的 特征种。类似的群系如栓皮柇+麻柇林(Quercus 
variabilis + Quercus acutissima Deciduous Broadleaf Forest Alliance)、虎榛子灌从(Ostryopsis davidiana Deciduous Broadleaf Shrubland Alliance)、红砂荒漠 (Reaumuria songarica Semi-Shrub and Herb Desert Alliance)、大针茅草地 (Stipa grandis Tussock Grassland Alliance)等。对于群落结构和物种组成较 为复杂的类型, 群落的建群种不明显, 群系的划分 要通过数量分类方法, 甄别出群落优势层或优势层 片的特征种, 或许也是共建种, 才能做出合理的群 系分类方案。

建群种、共建种或其他优势种的地理分布、生 长习性和形态外貌是复杂多样的。基于建群种或共 建种划分出的群系类型, 除了具有一组表征群系属 性的特征种外, 还具有稳定的地理分布范围, 包括 水平分布和垂直分布, 表征了其在群落的发生和生 态适应性等方面的特殊性; 具有特色鲜明的群落外 貌, 反映了生态、外貌的一致性。一个群系内的不 同群落之间, 在地理尺度上可以是间断的, 但生境 是连续的，即在相似的生境条件下群落可重复出现; 不同群系之间, 其核心群落至少在生态尺度上彼此 不重叠。

亚群系(Suballiance): 主要针对建群种生态幅 度较广的群系类型。在这些群系中, 可根据植物群 落生境条件的相对一致性, 例如属于同一个地貌或 土壤基质类型等, 划分出不同的亚群系。一个典型 的例子是琐琐荒漠(Haloxylon ammodendron SemiArbor and Shrub Desert Alliance), 可将生长在砂质 土、壤质土、砾质土和盐化土上的琐琐群落划分为 不同的亚群系(中国科学院中国植被图编辑委员会, 2007b)。一个群系的不同亚群系间, 群落次优势层 或层片的物种组成不同, 有一组表征各自群落属性 的特征种。

群丛组(Association Group): 一个群系内, 主 要基于群落结构特征, 即群落层或层片的同一性进 行划分, 一个群丛组内植物群落的分层结构是相同 的。此外, 对于一些植被类型, 如果基于层片结构特 征不能做出合理的分类方案, 群丛组的划分也可参 考次优势层片的优势种或共优种进行, 这些物种也 可能是群从组尺度上的特征种。

在“修订方案”及“80方案”关于群丛组的定义中, “层片结构相似”是群丛组划分的一级标准。由于“相 似”的尺度在实际工作中较难把握, 因此在实施过
程中, 群落层或层片相似性程度较高或相同的植物 群落可首先归入同一个群丛组。此外, “80方案”群丛 组划分的指标中还有“优势层片与次优势层片的优 势种或共优种相同”的表述。事实上，群落优势层片 的优势种, 即群落的建群种或共建种, 其分类学的 意义在于划分群系类型; 而次优势层或层片的优势 种, 又是一些群系类型中划分亚群系的相关指标之 一。群丛组是群系和亚群系之下的分类单位，其分 类方案应该建立在群落优势层片以外的其他层的物 种组成和群落结构特征的分化上面。次优势层片的 内涵在不同的植被类型之间差别较大。在森林群落 中, 次优势层片可能是中、小乔木层, 也可能是灌木 层或草本层; 在灌丛植被中, 次优势层片可能是小 灌木层或草本层; 在草本植被(草地)中, 次优势层 片可能是有别于优势层片的其他生活型的植物组 合。显然, 对于群落结构简单的森林植被、灌从和 草地而言, 群从组的划分要首先基于群落结构特 征。否则, 划分出的群从组数量会很多, 且容易混淆 群从组和群从之间的界限。

在群丛组的划分中, 分层的标准是特定层或层 片的盖度一般不小于 $20 \%$, 但对于荒漠等稀疏植被 可调整为更加合适的阈值。“80方案”提出了植物生 活型划分的 5 级分类系统， 《中国植被志》将主要按 第一级和第二级中的主要生活型对群落结构进行划 分, 即按照乔木、灌木、竹类、半灌木、草本植物 和苔藓等进行群落层片的划分, 第二级中的藤本、 附生和寄生类植物生活型一般不作为分层的依据。 在群从组的具体划分中, 可根据群落物种组成和结 构的复杂程度, 采用第三级(如针叶、阔叶, 从生草、 根茎草)或第四级(如常绿、落叶)生活型进行群落层 片的划分。群落分层结构是群丛组划分的一级分类 特征，而特征种的存在与否则是群从组划分的辅助 标准。事实上, 各群从组间通常具有各自的特征种。 例如, 在“青海云杉-草本 常绿针叶林”群从组和“青 海云杉-苔藓 常绿针叶林”群丛组中, 草本层和苔 藓层的某些物种就可能是各自的特征种。可见，上 述有关群从组的划分方案既充分体现了“80方案”所 提出的“凡是层片结构相似”的内涵，也秉承了《中 国植被志》以特征种划分植被类型的基本原则，保 证了植被分类方案的规范性和稳定性。基于以上原 则, 雪岭云杉林(群系)下的群丛组有“雪岭云杉-草 本 常绿针叶林”“雪岭云杉-草本-苔藓 常绿针叶林” 
“雪岭云杉-灌木-草本 常绿针叶林”和“雪岭云杉-落 叶阔叶树-草本 针叶与阔叶混交林”等类型(王国宏, 2017)。

一个群系或亚群系内的不同群丛组之间, 在空 间尺度上可以是连续的, 群落外貌相似, 但是群落 结构不同。群落环境的变化, 例如水平或垂直环境 梯度导致的水热条件的变化, 以及局地尺度上土壤 基质、干扰状况等方面的差异是群从组分异的主要 驱动因素。

群丛(Association): 一个群丛组内, 群丛的划 分主要基于群落间物种组成的不同, 同时也要参考 群落生境、群落的演替阶段和功能(如生产力)等因 素。在实际工作中, 群丛的划分首先要对样方数据 进行聚类分析, 分类方案的最终确定要综合考虑特 征种、群落生境和群落演替阶段等因素。一个群丛 组内的各个群从之间, 群落的外貌和结构相似, 但 群落的微环境, 如微地形、土层厚度和土壤排水状 况的变化会导致一些群落层, 特别是优势层片以外 的其他层片物种组成的变化。如果一个群丛组内有 2 个及以上的群丛, 各个群丛必然具有各自的特征种, 且一般不同于其所在群从组的特征种; 否则, 群丛 等级上的特征种与其所在的群从组的特征种相同。

综上所述, 群系组、群系、群从组和群从是在 不同的地理和生态尺度上对植物群落进行的分类, 反映了在由宽到窄的环境梯度上, 植物群落的外 貌、结构和组成等方面变化的规律性, 同时也揭示 出了一个区域内植被类型的多样性。在《中国植被 志》的研编过程中, 中级和低级植被分类单元的划 分在遵循“修订方案”和上述实施细则或工作方案的 基础上，可根据植被类型的特殊性、复杂性和资料 的丰富程度就植被分类的细节问题进行灵活处理, 力求分类方案的规范性、合理性和实用性。特别地, 对于样方资料薄弱的植被类型, 群从组的划分宜采 用较高级别的生活型单位进行群落分层, 群从的划 分也不宜过细。

\section{2 数据预处理}

在植被志所引证的样方中, 不同类型的数据应 进行归一化处理。数据分析中, 要计算出物种或层 片的重要值, 或将观测到的实测盖度转换为相对值; 对于Braun-Blanquet盖度值或者其他非连续盖度、多 度记录, 首先根据相应的区间, 利用随机数方法转 换为连续的数值, 再换算成相对值; 二元数据(出现
或否)样方只用于特征种、常见种和稀有种的甄别运 算。原始数据整理的结果最终形成3张Excel表格, 供进一步分析：样方基本信息表(附表3), 样方数据 汇总表(附表4)和物种-样方数据表(附表5)。附表3和 附表4主要用于各个植被类型群落结构和物种组成 特征的描述; 附表 5 可直接输入到JUICE程序中进行 植被分类运算。

\section{3 分类方法}

植被类型的划分采用数量分类的方法。对于群 落结构和物种组成相对简单的类型, 通常将相对盖 度、重要值或优势度(森林群落) $75 \%$ 确定为划分建 群种或共建种的阈值，据此划分出不同的群系或亚 群系。对于群落结构和物种组成复杂的类型, 例如 热带、亚热带地区的森林植被等, 应通过数量分类 方法, 首先对群落优势层或次优势层的物种进行分 类, 筛选出特征种, 进一步确定出群系的分类方案, 具体方法详见下文。

在群从组的划分中, 根据群落的垂直结构进行 群落分层，分层的标准是特定层的盖度不小于 $20 \%$, 一个群系内具有相同分层结构的群落可划归为一个 群从组。群落分层的总盖度可以采用野外调查中的 记录值, 也可以根据特定层中每个物种的分盖度计 算得出。计算方法(Jennings et al., 2009)如下:

$$
C_{i}=\left(1-\Pi\left(1-C_{j} / 100\right)\right) \times 100
$$

式中, $C_{i}$ 为群落中第 $i$ 层的百分比总盖度, $C_{j}$ 是第 $i$ 层 中的第 $j$ 个物种的百分比盖度 $(j=1-n, n$ 是一个层中 记录到的物种数目)。

森林植物群落的垂直分层通常包括乔木层、灌 木层、草本层和地被层等, 每一个层又可以划分出 若干个亚层。群落中的全部分层要统一编号。1-3 分别表示大、中、小乔木层; 4-6分别表示大、中、 小灌木层; 7-10分别代表大、中、小草本层及地被 层。对于一些特殊的层片结构, 例如在大灌木层中 又存在常绿灌木和落叶灌木 2 个层片, 可不单独编 号, 在群从组的划分中加以区别即可。在数据整理 表(附表4, 附表5)和分类结果汇总表(表1)中, 这些 层号都是一致的。图5展示了群落中各类生活型或生 长型的植物在群落分层中的归属方案。需要特别注 意的是, 上述群落分层编号并非图 5 中各类示例植 物的编号。群落的分层方案是在参考“80方案”的基 础上确定的, 详述如下。

乔木层可划分为大乔木层(高度 $\geqslant 25 \mathrm{~m}$ )、中乔 
木层 $(8 \mathrm{~m} \leqslant$ 高度 $<25 \mathrm{~m})$ 和小乔木层 $(5 \mathrm{~m} \leqslant$ 高度 $<8 \mathrm{~m})$ 3 个亚层, 出现在乔木层的竹类、大型灌木、附生植 物和藤本植物要统计为该层的物种, 因为其个体是 乔木层中稳定的组成成分。灌木层可划分为大灌木 层 $(200 \mathrm{~cm} \leqslant$ 高度 $<500 \mathrm{~cm})$ 和中灌木层 $(50 \mathrm{~cm} \leqslant$ 高度 $<200 \mathrm{~cm}$ ), 出现在草本层中的小灌木根据描述的需 要可划分为小灌木层(高度 $<50 \mathrm{~cm}$ )。显然, 小灌木层 与草本层是重叠的, 低矮匍匐的小灌木 (高度 $<30$ $\mathrm{cm})$ 也可统计为草本层的物种组成。需要指出的是, 出现在草本层中的小灌木或半灌木是一些具有特殊 生长或适应特性的物种, 将其统计为特定群落层片 的物种组成或许是为了便于描述或针对特定的研究 目的; 在植被志研编中, 应尽可能阐述其对群落结 构和功能的特殊作用。高度超过 $500 \mathrm{~cm}$ 的大型灌木, 不再统计为灌木层的物种组成; 出现在灌木层中的 竹类, 应根据高度统计为相应亚层的物种组成, 但 是出现在灌木层中的高大草本植物不统计为灌木层 的物种组成。草本层可划分为大草本层 $(30 \mathrm{~cm} \leqslant$ 高
度 $<50 \mathrm{~cm})$ 、中草本层 $(10 \mathrm{~cm} \leqslant$ 高度 $<30 \mathrm{~cm})$ 和小草 本层 (高度 $<10 \mathrm{~cm}$ ), 也可根据生长型进一步划分为 直立杂草层、莲座叶草本层、蔓生草本层、根茎和 从生禾草层等层片; 高度超过 $50 \mathrm{~cm}$ 的高大草本统 计在大草本层中, 并说明其具体的高度。地被层, 主 要由苔藓组成, 可成片或斑块状贴地生长在土层、 岩石和枯树干上, 也可能出现地衣、藻类和菌类等 (图5)。

森林群落的垂直分层复杂, 可能包括上述全部 的分层; 其他植被类型如灌丛、草本植被(草地)和荒 漠等, 可能只有1-3层。沼泽和水生植物群落也具有 垂直分层现象, 包括水上层(高草亚层、矮草亚层), 水面层(直立亚层、匍匐亚层)和水底层(水柱亚层、 基底亚层)等。

群丛的分类是以群丛组为单位, 数量分类不针 对特定群落层, 而是对一个群从组内所有的样方进 行再划分, 篮选出各个群从的一组特征种。因此, 用 于分类的数据表可将垂直分层适当简化，例如只划

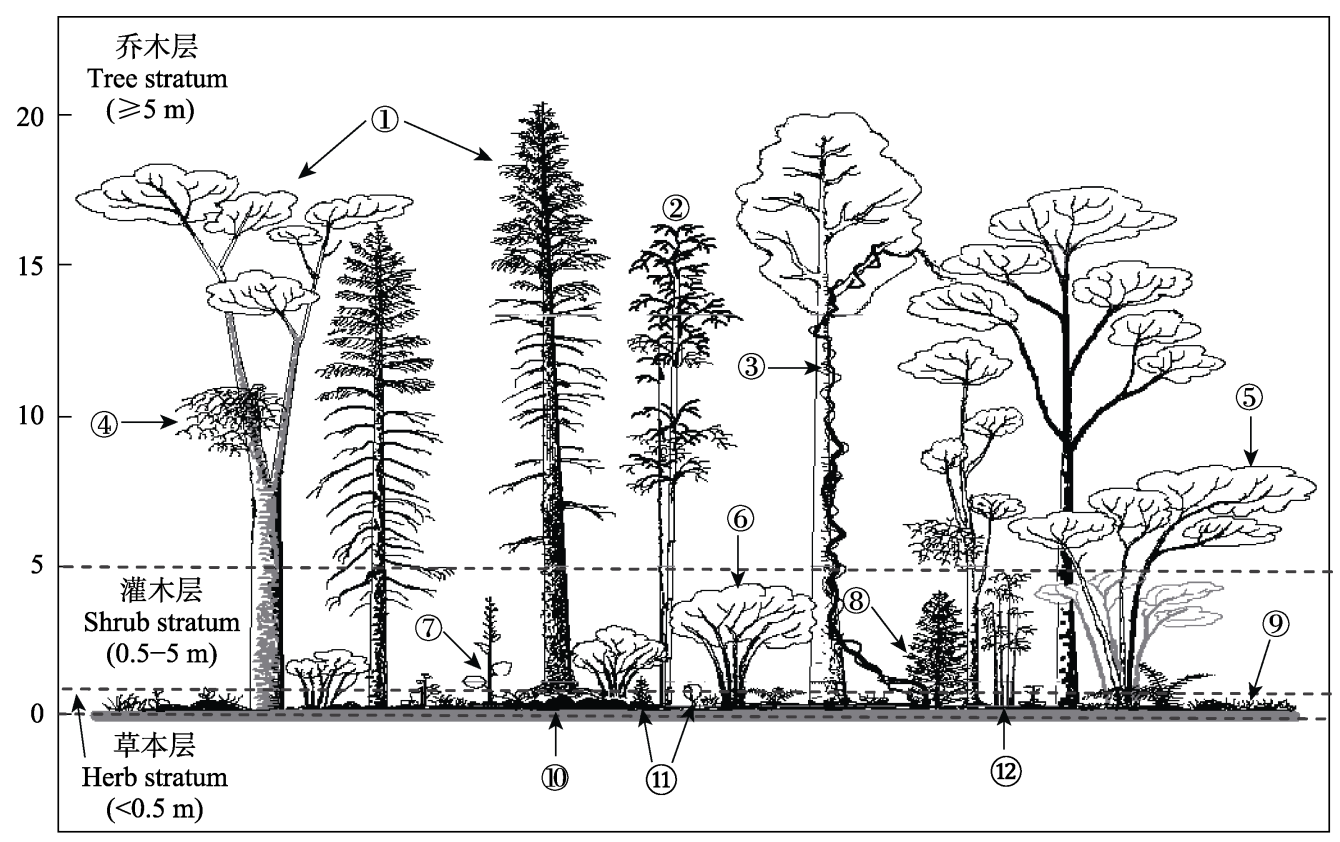

图5 植物群落垂直分层结构示意图。(1)乔木层的成年树木; (2)(3)(4)(5)分别是出现在乔木层中的竹类、木质藤本、寄生植物 和大型灌木, 统计为乔木层的物种; (6)灌木层的物种; (7)出现在灌木层的高大草本, 不统计为灌木层的物种; (8)(11) 和 (12)分别 是出现在灌木层和草本层的乔木的幼树/幼苗和竹类, 统计为相应层中的物种; 9)草本层的物种; 10苔蘚植物, 统计为地被层 的物种。

Fig. 5 An illustration of strata showing growth forms of individual plants as delineated. (1) mature trees, recorded as part of the tree stratum; (2), (3), (4) and (5) are bamboos, woody vines, parasitic plants and large shrubs that appear in the tree stratum, respectively, recorded as part of the tree stratum; (6) a plant having the shrub growth form but not projecting vertically into the tree stratum, recorded as part of the shrub stratum; (7) tall herbs although projecting vertically into the shrub stratum, recorded as part of the herb stratum; (8), (11) and (12) are samplings and bamboos that appear in the shrub and herb stratum, respectively, recorded as part of the corresponding stratum; (9) herb plants, recorded as part of the herb stratum; (10) mosses, recorded as part of the ground stratum (not delineated). 
分出乔木、灌木、草本和地被等 4 个层, 根据其生活 型或个体高度即可确定其所属的群落层片, 用于植 被特征描述和群丛的命名。特别强调, 在附表 4 和附 表 5 中, 每个物种是基于其生活型或个体的高度归 入到特定的群落层, 有固定的层号。表中群落层的 划分与各个层的盖度无关(图5)。

数量分类采用双向指示种分析方法(TWINSPAN) 或其他聚类分析方法, 将全部样方初步划归为不同 等级的植被分类单元(群系、群丛组、群丛)。根据 经验或相关记录, 对数量分类结果进行校正, 确定 最合理的分类方案。在此基础上, 计算每个物种的 特征值(fidelity value, 即 $\Phi$ 值)。利用Fisher严格检验 判断 $\Phi$ 值的显著性 $(p<0.05)$, 如果一个物种在特定 植被分类单元中出现和聚集的概率显著高于其他群 丛，该物种即可确定为特征种。显然，一组特征种是 表征植被分类单元鉴别特征的重要物种组合, 其存 在与否也是检验分类方案, 特别是群从划分方案合 理性的重要标准。由于各个植被分类单元所包含的
样方数存在差异, 在特征指数计算过程中, 以各分 类单元的样方数占总样方数比例的平均值作为固 定参数代入公式, 以消除因样方数量差异所造成 的影响。

分类方案确定后, 分类结果的表达及数据编辑 可参考JUICE程序(Tichy \& Holt, 2006)所介绍的方 法，其计算过程详见方框 1 。

特征种、常见种、偶见种的属性与研究的尺度 有关。例如, 一个物种在群系尺度上是特征种, 在群 丛组尺度上可能是常见种; 同样地, 一个群丛尺度 上的特征种, 可能是群丛组尺度上的偶见种。此外, 各个物种在群落中的属性与样本量的大小以及样方 的代表性有关。一般地, 随着样方数量的增加, 偶见 种的数量会逐渐增多, 特征种和常见种的数量会逐 渐减少。因此, 在群落分类中, 既要甄别出一定数量 的特征种, 又要覆盖一定数量的样方, 以反映出群 从的全貌, 这就需要在数量分类的前提下, 结合经 验和野外观测结果, 确定出合理的诊断阈值。通常

\section{方框1 JUICE程序计算过程}

Box 1 Calculation procedures for JUICE program

1 用于JUICE分析的数据表格(附表5), 由“样方-物种-层号-重要值/盖度值”(附表4)的数据转换而来。在附表 5 中, 第一 个单元格是文件名, 一般使用群系的科学名称或群系优势种的拉丁名, 占一行; 第二行是样方号, 所有样方号只能是数字 格式, 如果出现非数字格式的样方号, 要事先进行转换; 第一列是植物的拉丁名(从第三行开始, 下同), 第二列是物种所在 的层号, 后续各列是物种在样方中的相对盖度或重要值 $(0-100)$ 。数据整理好后复制到粘贴板。

2 JUICE软件导入数据路径: File-Import-Table。有7种文件格式可选, 常用“From Spreadsheet file (.csv)”或“From Clipboard as Spreadsheet”, 如果采用后者的导入方式, 则连续点击“Next”, 在盖度数据格式(Cover Values)中选择“Percentage Values”, 然后点击“Finish”。

3 数据导入完成后, 在“Analysis”栏目, 选择Twinspan或其他方法进行聚类分析, 分类结果要根据实际情况进行评估, 以确定出较为合理的分类方案。在调整分类方案过程中，可使用“Shift+鼠标左键”添加或删除样方间的分割线，用 “Shift十鼠标右键”可以给一个或一组样方选择颜色。如有必要, 可启动聚类分析程序对特定颜色覆盖的样方进行再分类。 由于中国植被分类专家系统没有建立起来，目前只能根据样方资料、环境条件等因子对数量分类的结果进行评估或修 正。分类结果表中默认的样方编码是系统自动生成的, 如果需要查看原始输入的样方号, 可在“Head”栏目中选择 “Original Number”。

4 分类方案确定后，点击“Synoptic Table”栏目，选择“Percentage Frequency”, 可保证数据表中显示频率值; 选择 “Fidelity”, 分类数据表中将显示特征值。在“Threshold Values”栏目可以设定相关阈值和对特征值进行Fisher检验的显著性 水平 $(\alpha=0.05,0.01,0.001)$ 。例如, 可设置诊断值 $25 、 50$ 分别为低诊断值的特征种和高诊断值的特征种的阈值; 同样地, 可 设置频率值60为常见种或恒有种的频率阈值; 可设置盖度值75为篮选单优势种的盖度阈值等。对不同属性的物种, 可在分 类表中用不同的颜色显示。阈值设置完成后，在“Synoptic Table”栏目，点击“Sort Species in Synoptic Table”, 在出现的提示 框中选择“Fidelity Measure”, 点击“Sort”, 即可显示分类表。

5 计算并输出结果: 点击“Synoptic Table”, 在“Analysis of Columns of Synoptic Table”中, 可以设置相关阈值(如果已经 设置, 此处可忽略), 点击“Export”- “Export Clusters 1- $n$ ” ( $n$ 是分类单元的个数, 在程序中将显示具体数字), 将输出每个植 被分类单元的特征种、常见种和优势种, 输出的文件名是“EXPORT.RTF”。连续点击“Close”和“Cancel”, 退出对话窗口。

6 数据输出路径: 点击File-Export, 在弹出窗口的第一行, 即显示输出文件“EXPORT.RTF”所在的路径。通过File一 Export-Synoptic Table路径, 可输出分类表到带逗号的.csv文件, 此文件可以用Word和Excel进行编辑。 
以 $0.25 \leqslant \Phi<0.50$ 和 $\Phi \geqslant 0.50$ 为依据划分普通特 征值物种和高特征值物种, 在群落分类表中分别以 浅灰色和深灰色的背景表达; 其次, 根据群落描述 所需要呈现的物种数量, 确定常见种和偶见种的相 关标准, 通常以频度 $\geqslant 60 \%$ 作为常见种的阈值。无 论是在样方尺度还是在植被类型(多个样方的组合) 的尺度上，应对优势种、次优势种、伴生种的确定 指标进行说明。在实际分类运算中, 可根据植被类 型、群落结构和物种组成的复杂程度对拟采用的指 标进行适当调整, 但是在植被志一个卷册中要保持 一致。

\section{4 分类结果}

植被分类结果的最终表达以群落分类简表、群 落环境和结构信息表、植被分类检索表和群落描述 正文等形式呈现。

\subsection{1 群落分类简表}

群落分类简表是群落分类结果的汇总, 包括所 划分出的分类单元(群从组和群从)的数量及其编号, 每个分类单元所包含的样方数, 每一个物种的分层
归属及频率值(或可显示特征值)等。

在群落分类简表中, 物种按照诊断指数由高到 低的次序排序，但表中也可选择呈现每个物种的频 度值, 以增加表格的信息量。普通特征值物种的频 度值在群落分类表中以浅灰色的背景标识，高特征 值物种的频度值以深灰色的背景标识, 这些物种是 植被分类的重要依据。群丛组和群从的分类结果要 分别列表呈现。在印刷版中, 表中通常只列出特征 种(中文名, 拉丁名), 其他物种作为附表列出。此外, 在每一个卷册的物种索引中, 根据每个物种后面所 附的群从组和群丛的系统编码, 也可追溯到其在植 被分类单元中的归属。表1是一个森林群系的群丛组 和群从分类简表的局部内容示例。

\subsection{2 群落环境和结构信息表}

群系、群从组和群从尺度上的群落环境和结构 信息可以汇总在同一个表中显示(示例见表2)。表中 的数据以群从为单位汇总，但可以通过分类单元间 的隶属关系判读出群系和群从组尺度上的相关信 息。表中包括群从组、群从的编号及凭证样方数, 各

表1 森林群系分类示例简表

Table 1 Synoptic table of a forest alliance

表3.7a 群丛组分类简表(局部示例)

Table 3.7a Synoptic table for association group (some examples)

\begin{tabular}{|c|c|c|c|c|c|c|c|}
\hline \multicolumn{3}{|c|}{ 群丛组号 Association group number } & \multirow{2}{*}{$\begin{array}{c}\mathrm{I} \\
46\end{array}$} & \multirow{2}{*}{$\begin{array}{c}\text { II } \\
6\end{array}$} & \multirow{2}{*}{$\begin{array}{l}\text { III } \\
12\end{array}$} & \multirow{2}{*}{$\begin{array}{l}\text { IV } \\
14\end{array}$} & \multirow{2}{*}{$\begin{array}{c}\mathrm{V} \\
20\end{array}$} \\
\hline 样方数 Numbe & & $\mathrm{L}$ & & & & & \\
\hline 冷偋 & Cystopteris fragilis & 7 & 28 & 0 & 0 & 0 & 0 \\
\hline 细叶孩儿参 & Pseudostellaria sylvatica & 7 & 15 & 0 & 0 & 0 & 0 \\
\hline 伞花繁缕 & Stellaria umbellata & 7 & 30 & 0 & 0 & 0 & 10 \\
\hline 疏花卷耳 & Cerastium pauciflorum & 7 & 0 & 83 & 0 & 0 & 0 \\
\hline 柄花茜草 & Rubia podantha & 7 & 2 & 33 & 0 & 0 & 0 \\
\hline 单侧花 & Orthilia secunda & 7 & 4 & 33 & 0 & 7 & 5 \\
\hline 鬼箭锦鸡儿 & Caragana jubata & 7 & 0 & 0 & 25 & 0 & 0 \\
\hline 天山花楸 & Sorbus tianschanica & 4 & 4 & 0 & 33 & 21 & 10 \\
\hline 密刺蓄薇 & Rosa spinosissima & 4 & 7 & 0 & 33 & 14 & 15 \\
\hline 硫黄棘豆 & Oxytropis sulphurea & 7 & 0 & 0 & 0 & 29 & 0 \\
\hline 天山柳 & Salix tianschanica & 3 & 0 & 0 & 25 & 57 & 0 \\
\hline 假报春 & Cortusa matthioli & 7 & 15 & 0 & 33 & 43 & 20 \\
\hline 昆仑方枝柏 & Juniperus centrasiatica & 3 & 0 & 0 & 0 & 0 & 45 \\
\hline 双花堇菜 & Viola biflora & 7 & 0 & 0 & 0 & 0 & 35 \\
\hline 火线草 & Leontopodium leontopodioides & 7 & 2 & 0 & 42 & 57 & 60 \\
\hline 新疆方枝柏 & Juniperus pseudosabina & 4 & 0 & 0 & 8 & 0 & 15 \\
\hline 雪岭云杉 & Picea schrenkiana & 4 & 15 & 0 & 75 & 86 & 70 \\
\hline 喜马拉雅沙参 & Adenophora himalayana & 7 & 0 & 0 & 58 & 50 & 60 \\
\hline 针茅 & Stipa sp. & 7 & 0 & 0 & 25 & 50 & 45 \\
\hline
\end{tabular}


表3.7b 群丛分类简表(局部示例)

Table 3.7b Synoptic table for association (some examples)

\begin{tabular}{|c|c|c|c|c|c|c|c|}
\hline \multicolumn{3}{|c|}{ 群丛组号 Association group number } & \multirow{2}{*}{$\begin{array}{l}\text { I } \\
1\end{array}$} & \multirow{2}{*}{$\begin{array}{l}\text { I } \\
2\end{array}$} & \multirow{2}{*}{$\begin{array}{l}\text { I } \\
3\end{array}$} & \multirow{2}{*}{$\begin{array}{l}\text { II } \\
4\end{array}$} & \multirow{2}{*}{$\begin{array}{r}\text { III } \\
5\end{array}$} \\
\hline 群丛号 Association number & & & & & & & \\
\hline 样方数 Number of plots & & $\mathrm{L}$ & 14 & 5 & 27 & 6 & 9 \\
\hline 细叶孩儿参 & Pseudostellaria sylvatica & 7 & 50 & 0 & 0 & 0 & 0 \\
\hline 早熟禾 & Poa annua & 7 & 29 & 0 & 0 & 0 & 0 \\
\hline 零余虎耳草 & Saxifraga cernua & 7 & 21 & 0 & 0 & 0 & 0 \\
\hline 新疆臺草 & Carex turkestanica & 7 & 0 & 100 & 0 & 0 & 11 \\
\hline 达乌里卷耳 & Cerastium davuricum & 7 & 0 & 80 & 4 & 0 & 0 \\
\hline 裂叶婆婆纳 & Veronica verna & 7 & 0 & 40 & 0 & 0 & 11 \\
\hline 淡紫金莲花 & Trollius lilacinus & 7 & 0 & 40 & 0 & 0 & 0 \\
\hline 冷偋 & Cystopteris fragilis & 7 & 0 & 0 & 48 & 0 & 0 \\
\hline 无芒雀麦 & Bromus inermis & 7 & 0 & 0 & 19 & 0 & 0 \\
\hline 火烧兰 & Epipactis helleborine & 7 & 0 & 0 & 15 & 0 & 33 \\
\hline 弯刺菩薇 & Rosa beggeriana & 4 & 0 & 0 & 15 & 0 & 0 \\
\hline 疏花卷耳 & Cerastium pauciflorum & 7 & 0 & 0 & 0 & 83 & 0 \\
\hline 欧洲鳞毛蕨 & Dryopteris filix-mas & 7 & 0 & 0 & 4 & 33 & 0 \\
\hline 细叶拟金发蘚 & Polytrichum longisetum & 10 & 0 & 0 & 7 & 33 & 0 \\
\hline 异株菖麻 & Urtica dioica & 7 & 0 & 20 & 4 & 33 & 11 \\
\hline 大花车轴草 & Trifolium eximium & 7 & 0 & 0 & 7 & 33 & 0 \\
\hline 平卧黄芩 & Scutellaria prostrata & 7 & 0 & 0 & 0 & 0 & 0 \\
\hline 多叶锦鸡儿 & Caragana pleiophylla & 7 & 0 & 0 & 0 & 0 & 0 \\
\hline 小叶忍冬 & Lonicera microphylla & 4 & 36 & 0 & 4 & 0 & 0 \\
\hline 密刺蓄薇 & Rosa spinosissima & 4 & 21 & 0 & 0 & 0 & 44 \\
\hline 大穗薹草 & Carex rhynchophysa & 7 & 0 & 0 & 0 & 0 & 22 \\
\hline 水栒子 & Cotoneaster multiflorus & 4 & 36 & 20 & 19 & 0 & 56 \\
\hline 圆叶鹿蹄草 & Pyrola rotundifolia & 7 & 0 & 60 & 0 & 17 & 33 \\
\hline 拟漆姑 & Spergularia marina & 7 & 0 & 40 & 0 & 0 & 0 \\
\hline 库地臺草 & Carex curaica & 7 & 0 & 0 & 44 & 0 & 0 \\
\hline 山地乌头 & Aconitum monticola & 7 & 0 & 0 & 0 & 50 & 0 \\
\hline 新疆缬草 & Valeriana fedtschenkoi & 7 & 0 & 0 & 0 & 0 & 22 \\
\hline 针叶石竹 & Dianthus acicularis & 7 & 0 & 0 & 0 & 0 & 0 \\
\hline 天山柳 & Salix tianschanica & 3 & 0 & 0 & 0 & 0 & 11 \\
\hline 喜马拉雅沙参 & Adenophora himalayana & 7 & 0 & 0 & 0 & 0 & 44 \\
\hline 红花鹿蹄草 & Pyrola asarifolia subsp. incarnata & 7 & 43 & 20 & 4 & 0 & 22 \\
\hline 伊犁小檗 & Berberis iliensis & 4 & 0 & 0 & 0 & 0 & 33 \\
\hline 准噶尔马先蒿 & Pedicularis songarica & 7 & 0 & 0 & 0 & 0 & 33 \\
\hline 三小叶当归 & Angelica ternata & 7 & 43 & 0 & 0 & 0 & 0 \\
\hline 火绒草 & Leontopodium leontopodioides & 7 & 0 & 0 & 4 & 0 & 56 \\
\hline 岩参 & Cicerbita azurea & 7 & 93 & 100 & 15 & 83 & 0 \\
\hline
\end{tabular}

说明: 表中数据可为物种频率值 (\%) 或特征值 $(\%)$, 物种按特征值 $(\Phi)$ 递减的顺序排列。 $\Phi \geqslant 0.25$ 和 $\Phi \geqslant 0.5(p<0.05)$ 的物种为特征种, 其频率 值或特征值分别标记浅灰色和深灰色。表中 “L” 列为物种所在的群落层号, 1 3分别表示大、中、小乔木层, 4 6分别表示大、中、小灌木层, 7 10分别代表大、中、小草本层及地被层。

Note: The numbers in the table are percentage frequencies or fidelity values. Species are sorted and ranked by decreasing fidelity (phi coefficient) within each association. Light and dark grey background indicates fidelity of $\Phi \geq 0.20$ and $\Phi \geq 0.50(p<0.05)$, respectively. These species are considered as diagnostic species. The column marked with "L" is the code of community vertical layer. 1, tree layer (high); 2, tree layer (middle); 3, tree layer (low); 4, shrub layer (high); 5 , shrub layer (middle); 6, shrub layer (low); 7, herb layer (high); 8, herb layer (middle); 9, herb layer (low); 10, moss layer.

www.plant-ecology.com 
表2＼cjkstart森林群系中各群从组和群丛的环境和群落结构信息表(示例)

Table 2 Example data for environmental characteristics and supraterraneous stratifications of association groups and associations from a forest alliance

表3.8 群丛组和群丛的环境和群落结构信息表(局部示例)

Table 3.8 Data for environmental characteristics and supraterraneous stratifications of association groups and associations (some examples)

\begin{tabular}{|c|c|c|c|c|c|c|c|c|c|c|c|c|c|c|c|c|c|c|c|c|}
\hline \multirow{2}{*}{$\begin{array}{l}\text { 群从组 } \\
\text { Asso- } \\
\text { ciation } \\
\text { group }\end{array}$} & \multirow{2}{*}{$\begin{array}{l}\text { 群从 } \\
\text { Asso- } \\
\text { ciation }\end{array}$} & \multirow{2}{*}{$\begin{array}{c}\text { 样方 } \\
\text { 数 } \\
\text { Num- } \\
\text { ber of } \\
\text { plots }\end{array}$} & \multirow{2}{*}{$\begin{array}{c}\text { 海拔 } \\
\text { Alti- } \\
\text { tude } \\
(\mathrm{m})\end{array}$} & \multirow{2}{*}{$\begin{array}{l}\text { 地貌 } \\
\text { Ter- } \\
\text { rain }\end{array}$} & \multirow{2}{*}{$\begin{array}{c}\text { 坡度 } \\
\text { Slope } \\
\left(^{\circ}\right)\end{array}$} & \multirow{2}{*}{$\begin{array}{c}\text { 坡向 } \\
\text { Aspect } \\
\left(^{\circ}\right)\end{array}$} & \multirow{2}{*}{$\begin{array}{c}\text { 坡位 } \\
\text { Loca- } \\
\text { tion }\end{array}$} & \multicolumn{4}{|c|}{$\begin{array}{c}\text { 乔木层 } \\
\text { Tree stratum }\end{array}$} & \multicolumn{3}{|c|}{$\begin{array}{c}\text { 灌木层 } \\
\text { Shrub stratum }\end{array}$} & \multicolumn{3}{|c|}{$\begin{array}{c}\text { 草本层 } \\
\text { Herb stratum }\end{array}$} & \multicolumn{3}{|c|}{$\begin{array}{c}\text { 地被层 } \\
\text { Ground stratum }\end{array}$} \\
\hline & & & & & & & & $\begin{array}{c}\text { 盖度 } \\
\text { Cover } \\
(\%)\end{array}$ & $\begin{array}{l}\text { 胸径 } \\
\text { DBH } \\
(\mathrm{cm})\end{array}$ & $\begin{array}{c}\text { 高度 } \\
\text { Height } \\
(\mathrm{cm})\end{array}$ & $\begin{array}{c}\text { 物种数 } \\
\text { No. } \\
\text { species }\end{array}$ & $\begin{array}{c}\text { 盖度 } \\
\text { Cover } \\
(\%)\end{array}$ & $\begin{array}{c}\text { 高度 } \\
\text { Height } \\
(\mathrm{cm})\end{array}$ & $\begin{array}{c}\text { 物种数 } \\
\text { No. } \\
\text { species }\end{array}$ & $\begin{array}{c}\text { 盖度 } \\
\text { Cover } \\
(\%)\end{array}$ & $\begin{array}{c}\text { 高度 } \\
\text { Height } \\
(\mathrm{cm})\end{array}$ & $\begin{array}{c}\text { 物种数 } \\
\text { No. } \\
\text { species }\end{array}$ & $\begin{array}{c}\text { 盖度 } \\
\text { Cover } \\
(\%)\end{array}$ & $\begin{array}{c}\text { 高度 } \\
\text { Height } \\
(\mathrm{cm})\end{array}$ & $\begin{array}{c}\text { 物种数 } \\
\text { No. } \\
\text { species }\end{array}$ \\
\hline \multirow[t]{3}{*}{ I } & 1 & 8 & $1420^{\mathrm{a}}$ & VA & 18 & $300^{\mathrm{d}}$ & LS & 30 & 22 & 15 & 2 & 32 & 118 & 5 & 68 & 13 & 22 & 0 & 0 & 0 \\
\hline & & & $1343^{b}$ & & 5 & $0^{\mathrm{e}}$ & & 20 & 2 & 3 & 1 & 20 & 40 & 3 & 63 & 1 & 17 & 0 & 0 & 0 \\
\hline & & & $1562^{\mathrm{c}}$ & & 30 & & & 50 & 49 & 26 & 2 & 49 & 250 & 8 & 72 & 50 & 25 & 0 & 0 & 0 \\
\hline \multirow[t]{3}{*}{ II } & 2 & 6 & 2110 & MO & 30 & 230 & MS & 50 & 17 & 14 & 2 & 0 & 0 & 0 & 100 & 27 & 7 & 1 & 5 & 1 \\
\hline & & & 2002 & & 18 & 0 & & 30 & 5 & 3 & 2 & 0 & 0 & 0 & 100 & 5 & 7 & 1 & 5 & 1 \\
\hline & & & 2280 & & 38 & & & 80 & 36 & 23 & 2 & 0 & 0 & 0 & 100 & 50 & 7 & 1 & 5 & 1 \\
\hline \multirow[t]{3}{*}{ II } & 3 & 12 & 2470 & $\mathrm{MO}$ & 22 & 345 & LS & 55 & 18 & 15 & 2 & 5 & 27 & 1 & 89 & 18 & 13 & 5 & 4 & 1 \\
\hline & & & 2310 & & 9 & 20 & MS & 20 & 3 & 3 & 1 & 0 & 0 & 0 & 55 & 3 & 7 & 1 & 0 & 0 \\
\hline & & & 2670 & & 38 & & US & 70 & 45 & 29 & 3 & 10 & 250 & 3 & 100 & 70 & 20 & 40 & 10 & 6 \\
\hline \multirow[t]{3}{*}{ III } & 4 & 6 & 2280 & MO & 30 & 340 & MS & 56 & 19 & 17 & 3 & 38 & 89 & 6 & 85 & 26 & 16 & 6 & 7 & 2 \\
\hline & & & 2160 & & 25 & 30 & US & 50 & 3 & 3 & 2 & 20 & 40 & 3 & 80 & 4 & 13 & 0 & 5 & 1 \\
\hline & & & 2410 & & 40 & & & 70 & 60 & 33 & 3 & 50 & 300 & 9 & 90 & 150 & 23 & 30 & 10 & 3 \\
\hline
\end{tabular}

a: 平均值; b: 最小值; c: 最大值; d: 顺时针方向的起始值; e: 顺时针方向的终止值; MO: 山地; VA: 河谷; LS: 下坡; MS: 中坡; US: 上坡 a: Mean; b: Minimum; c: Maximum; d: Starting value in clockwise direction; e: Termination value in clockwise direction; MO: Montane; VA: Valley; LS: Lower slope; MS: Middle slope; US: Upper slope

样方的环境因子(海拔、地貌、坡度和坡向等)信息 汇总，群落乔木层、灌木层、草本层和地被层的总 盖度、胸径(针对乔木层)、高度和物种丰富度的平 均值、最小值和最大值。

海拔和坡度可填写平均值、最小值和最大值。 地貌和坡位可用其英文的缩写表达(附表6)。例如， 一个群丛如果出现在山地和丘陵地带的下坡和中坡, 地貌一栏可填写为“MO”和“HI”，坡位一栏可填写 “LS”和“MS”，分别占一个单元格。坡向以顺时针方 向标出坡向方位角的起始值和终止值, 二者所确定 的坡向范围要包含一个群丛中所有样方的坡向数据, 而且在所有的选项中, 沿顺时针方向的旋转角度最 小。如果坡向的原始记录包含描述性的信息, 可根 据实际情况转换为方位角。例如, 西北坡、北坡和 东北坡可分别赋值为 $315^{\circ} 、 0^{\circ}$ 和 $45^{\circ}$ 。特别说明，附 表6中列举的地形、地貌相关术语的英文名称缩写仅 在《中国植被志》中可以不加说明直接使用, 应用 于其他领域则需遵守该领域的相关规定。

\subsection{3 植被分类检索表}

植被分类是基于植物群落的外貌、结构和物种 组成等方面的变化, 将植物群落或植物群落组合划 分为不同的植被类型。植被类型之间既区别明显也 相互关联, 其区别和关联的程度在不同的植被类型
之间存在较大差异。因此，一个合理的植被分类方 案总可以通过自上而下等级式的分类树加以汇总。 植被分类检索表是对植被分类方案进行的高度汇总 和归纳，以二歧式表格提炼各个植被分类单元的关 键特征, 并展示出各植被类型之间的内在关联(方 框2)。因此，植被分类检索表既是快速掌握植被类 型关键特征、鉴别植被类型的重要工具，其编制过 程也是对植被分类方案合理性的检验。根据植被分 类单位的等级，植被分类检索表可有多种类型。《中 国植被志》各卷册主要针对中级和低级植被分类单 元编制植被分类检索表。

同一个群系中的群丛组和群丛, 视所包含的植 被类型的多少，可以放在同一个检索表中或者不同 的检索表中。在植被分类检索表编制中，对植被特 征的归纳一般要遵循群落的外貌、群落分层、各个 层的特征种或优势种等逐级深入，按照二歧式结构 编制。植被类型较少的分支要放在二歧式结构的首 个分支。通常要选择频度较大(不低于 $60 \%$ )的特征种 和容易观测的环境信息作为二歧分支的鉴别特征。 为了便于检索表的应用，表中的物种信息一般使用 盖度值, 野外可以直接读取; 环境信息一般要选择 在野外可以直接观测和观察到的因子, 如海拔、地 貌、坡度、坡向、坡位、土层厚度或土壤基质等。 
方框2 青海云杉林分类检索表局部示例

Box 2 A part of the key to Picea crassifolia Forest Alliance

A1 乔木层由青海云杉单优势种组成，相对优势度 $\geqslant 75 \%$ 。

B1 苔藓层盖度 $\geqslant 20 \%$, 无灌木或有稀疏的灌木和草本植物（盖度 $<20 \%$ )。PC-I 青海云杉-苔蘚 常绿针叶林 Picea crassifolia - Moss Evergreen Needleleaf Forest

B2 林下灌木稀疏，草本层盖度 $\geqslant 20 \%$ ；或兼有灌木层和草本层，二者的盖度 $\geqslant 20 \%$ 。

C1 林下灌木稀疏，盖度 $<20 \%$; 草本层盖度 $\geqslant 20 \%$ 。PC-II 青海云杉-草本 常绿针叶林 Picea crassifolia - Herb Evergreen Needleleaf Forest

C2 林下有明显的灌木层和草本层, 二者的盖度 $\geqslant 20 \%$ 。PC-III 青海云杉-灌木-草本 常绿针叶林 Picea crassifolia

- Shrub - Herb Evergreen Needleleaf Forest

A2 乔木层除了青海云杉（相对优势度 $<75 \%$ ）外，还有青扦、杜松、山杨和桦木等针阔叶乔木混生，组成共优势种。

B1 乔木层由青海云杉和青扞组成共优势种。PC-IV 青海云杉+青扦-灌木-草本 常绿针叶林 Picea crassifolia + Picea wilsonii - Shrub - Herb Evergreen Needleleaf Forest

B2 乔木层由青海云杉、杜松和杨桦等阔叶乔木组成。PC-V 青海云杉-山杨-杜松-灌木-草本 针叶与阔叶混交林 Picea crassifolia - Populus davidiana - Juniperus rigida - Shrub - Herb Mixed Needleleaf and Broadleaf Forest

检索表中所提炼出的关键分类特征要与正文中的相 关描述一致, 不能出现与正文冲突的描述。检索表 中的语言要力求简洁准确, 避免午长的语句。

对于群落结构较为复杂或群落类型较为丰富的 植被类型，检索表的编制也可以借助“分类和回归 树算法” (CART; Breiman et al., 1984)进行。这种算 法的优点是可以充分利用物种信息和环境信息, 篮 选出最好的因子(物种和环境因子)去表征二歧分支; 缺点是每一个物种都要根据盖度值的阈值进行二歧 划分, 对于高特征值物种可能无法体现。因此, 如果 是采用 “分类和回归树算法”得出的结论, 还需要根 据经验进行最后的确认和修改, 以便于使用。“分类 和回归树算法”的 R软件 rpart包下载网址： http:// CRAN.R-project.org/package=rpart。Windows版本的 下载网址: https://www.salford-systems.com。

群落描述的撰写规范参见本文第6部分。

\section{5 植被命名规范}

\section{1 国际植被命名方法概述}

以Braun-Blanquet分类系统为依据制定的《国际 植物群落命名法规》 (International Code of Phytosociological Nomenclature, ICPN; Weber et al., 2000), 以植物拉丁名中属名后面增加不同的终止词, 表达 群落分类单元的等级(例如: Association, -etum; Alliance, -ion; Order, -etalia; Class, -etea; Subassociation, -etosum; Suballiance, -enion; Suborder, -enalia; Subclass, -enea)。这个法规的优点是简洁规范, 缺点是 名称中完全没有群落结构信息, 植被名称的符号意 义大于指示意义。对于植被分类单元这样一个基于
样方数据统计分析所确定的群落组合，如果植被名 称偏重符号意义, 则很难应用于植被清查和保护等 实际工作中。

英美等国家采用更加实用的植被命名方法, 植 被名称中出现了反映不同层片优势种/特征种的信 息, 但命名方式也不统一。在美国植被分类系统 (Federal Geographic Data Committee, 2008)中，植被 名称后可增加分类等级名称以示区别(亦可不加)。例 如: Pseudotsuga menziesii - Quercus garryana - Pinus ponderosa - Arbutus menziesii Macrogroup, Pinus ponderosa - Quercus garryana - Pseudotsuga menziesii Group, Pinus ponderosa - Quercus garryana Woodland Alliance, Pinus ponderosa - Quercus garryana / Balsamorhiza sagittata Woodland Association 。

在英国《British Plant Communities》系列丛书 中, 植物群落命名分为群落 (community) 和亚群落 (sub-community)两个等级(Rodwell et al., 1991)。群 落名称后面除了增加显示植被类型的词汇(例如 woodland)外, 不显示等级名称, 如Fraxinus excelsiorSorbus aucuparia-Mercurialis perennis woodland; 亚 群落名称如Crepis paludosa sub-community, 后面只 显示等级名称“sub-community”。

由于植被分类的复杂性, 目前国际上尚没有一 个权威的和被唯一接受的植被分类命名法规。英美 等国所采用的植被命名方法兼有简明和实用的特征, 在植被分类描述过程中容易理解和接受。

《中国植被志》拟采用的植被命名方法, 在参考 英美等国的植物群落命名方法的基础上, 将根据 “80方案”所提出的植被分类基本原则制定。“80方 
案”对中国植被中级和低级分类单元的划分与界定， 例如对群系、群丛组和群丛的界定, 已经被国内同 行广泛采用。其中有关“群丛”的界定和含义, 即群 落外貌、结构、物种组成和生境相对一致的群落组 合, 与国际上绝大多数植被分类系统中的基本分类 单位“Association”具有较高的对应性。但是, “80方 案” 中的群丛组和群系, 与国际主要分类系统中相 关单元的对应性尚不确定或存在争议。因此, 在遵 循既要综合考虑植被分类单位英文名称与中文名称 含义的对应性, 又要与国外相关研究接轨, 便于国 际交流原则的基础上, 我们提出了中国植被中级和 低级分类单位的命名方案, 即群系的英文名称拟采 用国际植被分类中的中级单位名称“Alliance”, 群 系组和亚群系分别采用“Alliance Group”和“Suballiance”; 群从采用国际通用的对等名称“Association”, 群丛组采用“Association Group” (方精云等, 2020)。

\section{2 《中国植被志》植被类型命名总则}

群系组、群系、群从组和群从的科学名称, 由 植物拉丁名或拉丁名组合外加限定词组成。植物拉 丁名采用简写名称(即不包含命名人的名称), 斜体 排版; 其他英文词汇用正体。限定词是指植被型组、 植被型或植被亚型的英文名称与群系组、群系、群 从组和群从本身的英文名称的组合, 每个实词首字 母大写。植被型组、植被型或植被亚型的划分方案 及中英文名称以中国植被分类系统的最新修订方案 为依据(方精云等, 2020; 郭柯等, 2020)。对于一些具 有限定意义的英文名称, 尽可能采用具有名词性质 的英文词汇，兼顾词汇使用中的对等性原则。例如， “针叶林” 和 “阔叶林”对应的英文名称分别使用

“Needleleaf Forest”和“Broadleaf Forest”。

植被的中文名称是其科学名称的中文直译。植 物拉丁名及其中文名称, 应采用最新的、权威的植 物分类专著中所接纳的名称, 如 《Flora of China》; 科学名称中的限定词, 其中文名称与所在的植被型 的中文名称一致。例如, “Evergreen Needleleaf Forest”对应的中文是“常绿针叶林”。对于一些长期使用 的中文名称, 特别是群系组、群系的中文名称, 建议 保留习惯用法, 不必采用科学名称的中文直译。如 “森林”“落叶阔叶林”和“常绿阔叶林”等在群系组、 群系、亚群系等中级植被分类单元的中文名称中均 可简称为 “林”。例如, “Picea likiangensis var. rubescens Evergreen Needleleaf Forest Alliance”中文 直译是“川西云杉常绿针叶林”, 其习惯用法“川西 云杉林”可以作为中文名称予以保留。同理, “Reaumuria songarica Semi-Shrub and Herb Desert Alliance”的中文名称可以采用“红砂荒漠”。对于群从组 和群丛的中文名称, 以及非习惯用法的群系组或群 系的中文名称, 采用科学名称的中文直译即可。总 之, 植被类型中文名称的限定词简称的使用, 在尊 重中文习惯用法或朗读习惯的基础上, 尽可能地与 科学名称保持一致。

\section{3 群系组的命名}

群系组的名称由一个属或多个属的名称(中文 名、拉丁名)加限定词组成。用于群系组命名的属, 其包含的部分或全部物种一定是一个植被型组或植 被型内若干个群系的建群种或共建种。如果群系组 名称中包含 2 个以上的属, 则属名依照其在群落中 的重要性序列依次出现，属名之间以连字符“-”相 连。中文名之间以及属的拉丁名之间的“-”两侧不留 空格。群系组科学名称的限定词由植被型组或植被 型的英文名称与群系组的英文“Alliance Group”组 成。“Alliance Group”具有限定词的意义, 可以表征 一个植被类型所属的植被分类等级。中文限定词与 植物中文名之间不加空格; 英文限定词与植物拉丁 名之间按照英文格式书写即可。作为群系组命名的 限定词, 所选用植被型组或植被型的名称一定要能 够包含这个群系组中出现的所有植被类型。例如, 在针叶林这个植被型内, 落叶松林、冷杉林、云杉 林和松林等都是独立的群系组, 但所包含的植被型 有“针叶林” 和“针叶与阔叶混交林”两种, 用于群系 组的限定词就只能用“森林”植被型组的名称。再如, 栲林、青冈林、石柇林、木荷林等都可以成为独立 的群系组, 在其所描述的植被类型中, 除了“常绿阔 叶林”外, 如果没有其他的植被类型, 用于群系组命 名的限定词就可以使用“常绿阔叶林”这个植被型的 名称。如果群系组是根据生活型或生境类型进行划 分的, 可根据生活型或生境类型相应的英文名称与 “Alliance Group”组合, 确定这类特殊群系组的科学 名称。

群系组命名举例:

- 云杉林 Picea Forest Alliance Group

- 栋林 Quercus Forest Alliance Group

- 栲林 Castanopsis Evergreen Broadleaf Forest 
Alliance Group

- 沙拐束荒漠 Calligonum Semi-Arbor and Shrub Desert Alliance Group

- 针茅草地 Stipa Tussock Grassland Alliance Group

在《中国植被志》的编排系统中, 如果一个卷 册只包含一个群系组, 这个卷册的中英文书名应采 用群系组的科学名称。例如，《中国植被志》“云杉 林”册, 其英文书名应使用 “云杉林” 群系组的科学 名称, 即“Picea Forest Alliance Group”。如果一个卷 册中包含多个群系组, 卷册的中英文书名一般采用 植被型组、植被型或植被亚型等高级分类单位名称 外加各自的限定词(即植被型组、植被型或植被亚型 的英文名称)。例如, 在《中国植被志》荒漠植被卷 册中, “半乔木与灌木荒漠”卷的英文名称可以使用 "Semi-Arbor and Shrub Desert Vegetation Formation", 这个植被型包含了沙冬青荒漠 (Ammopiptanthus Semi-Arbor and Shrub Desert Alliance Group)、沙拐 杳荒漠(Calligonum Semi-Arbor and Shrub Desert Alliance Group)等多个群系组。

\section{4 群系、亚群系的命名}

群系的名称由群落的建群种或共建种(即优势 层的优势种或共优势种)的植物名称(中文名、拉丁 名)加限定词组成。群系中文名称的限定词可用简称; 其科学名称的限定词由植被型组或植被型等级上的 植被类型的英文名称和“群系”的英文“Alliance”组 成。“Alliance”具有限定词的意义, 可以表征一个植 被名称所属的植被分类等级, 中文名称的限定词与 植物名称之间不加空格。如果有 2 个共建种, 二者的 名称之间以“+”相连。植物中文名之间的“+”两侧不 加空格, 植物拉丁名之间的“+”两侧加 1 个半角空格。 群系名称中的植物名称，一般不超过 2 个。

在植被界，一种植物可以是一个群落的单优势 种, 也可能与其他植物混生而成为群落的共优势 种。例如, 雪岭云杉可以单优势种组成常绿针叶林, 也可与西伯利亚落叶松 (Larix sibirica) 组成落叶与 常绿针叶混交林, 以及与落叶阔叶树组成针叶与阔 叶混交林。在植被志的编排系统中, 这些由同一个 物种所组成的单优势植物群落或植被类型, 以及以 该物种为共优势种之一所组成的复杂植被类型, 一 般都放在以该物种所冠名的群系中进行描述。但是, 这样的群系类型, 其名称限定词的选择要取决于这
个群系内所包含的植被类型的复杂程度。限定词所 表征的植被分类等级应能够包含所描述的全部植被 类型, 即要高于或等于(适用于所描述的植被类型属 于同一个植被型的情形)所描述的植被类型等级。下 面以雪岭云杉林和川西云杉林为例说明其命名规范。

“雪岭云杉林”群系所描述的植被类型可以划分 为“森林”植被型组之下的2-3个植被型, 即“常绿针 叶林”和“针叶与阔叶混交林”等。因此，“雪岭云杉 林”这个群系的名称就由“雪岭云杉”的植物名称与 “森林”植被型组的中英文名称组合而成, 而不可使 用上述几个植被型名称中的任何一个作为限定词。 所以，雪岭云杉林的中文名称是 “雪岭云杉森林”, 可简称为 “雪岭云杉林”, 科学名称是 “Picea schrenkiana Forest Alliance"。

“川西云杉林”群系所包含的植被类型均属于 “常绿针叶林”这个植被型，其名称由“川西云杉”的 植物名称与“常绿针叶林”这个植被型的名称组合而 成，即“川西云杉常绿针叶林”，简称为“川西云杉 林”; 其科学名称是“Picea likiangensis var. rubescens Evergreen Needleleaf Forest Alliance”。

亚群系的命名规范与群系类似, 在群落的建群 种或共建种的植物名称(中文名、拉丁名)之后，以 “-”间隔, 添加次优势层的特征种或优势种, 或表征 特定生境类型的英文词汇, 外加限定词Suballiance 组成。亚群系的中文名称可采用习惯用法。

群系命名举例:

- 雪岭云杉林 Picea schrenkiana Forest Alliance

- 栓皮栋+麻栋林 Quercus variabilis + Quercus acutissima Deciduous Broadleaf Forest Alliance

- 虎榛子灌丛 Ostryopsis davidiana Deciduous Broadleaf Shrubland Alliance

- 红砂荒漠 Reaumuria songarica Semi-Shrub and Herb Desert Alliance

- 大针茅草地 Stipa grandis Tussock Grassland Alliance

亚群系命名举例:

- 山地白扞林 Picea meyeri Montane Forest Suballiance

- 沙地白扦林 Picea meyeri Sandland Evergreen Needleleaf Forest Suballiance

\section{5 群丛组的命名}

群丛组的名称由群落的建群种或共建种(即优 
势层的优势种或共优势种)的拉丁名与群落中次优 势层(以各层总盖度不小于 $20 \%$ 为衡量标准)优势植 物生活型的名称以及限定词组成。在一些植被类型 中, 如果次优势层的优势种或特征种对群从组划分 具有重要的鉴别作用, 该物种的名称可替代次优势 层的生活型名称出现在群从组的名称中。

植物生活型的名称如乔木(tree)、灌木(shrub)、 竹(bamboo)、草本(herb)、苔藓(moss)等, 将出现在 群从组的名称中。同一个层中的多个物种名之间以 “+”相连，中文名称之间的“+”两侧不留空格，拉丁 名或英文单词之间的“+”两侧留 1 个半角空格。不同 群落层的物种或生活型名称之间以“-”分隔。中文名 之间的“-”两侧不留空格, 拉丁名之间、拉丁名与英 文单词之间, 以及英文单词之间的“-”两侧留 1 个半 角空格。一个群丛组的名称中, 植物拉丁名一般不 超过 2 个, 建群种或优势种排在前面, 生活型名称的 数目由群落的分层状况确定。为了便于阅读, 在群 从组及群丛的中英文名称中, 限定词与主体部分之 间一般要留 1 个半角空格。

群从组名称的限定词是植被型的名称。如果一 个群系内所有的群丛组属于同一个植被型, 则群丛 组名称的限定词与其所在群系名称的限定词相同; 如果一个群系内的群丛组可归入多个植被型, 群丛 组名称的限定词要与其所在的植被型名称一致。群 丛组的科学名称后一般不加限定词 “Association Group”, 因为其名称本身具有明显的区别特征, 即 出现了表征植物生活型的英文单词。在一些特殊的 情形下, 如果群系、群从组和群从三者的植物名称 组合完全相同, 在科学名称后要附加各自的限定词。

群从组命名举例:

- 雪岭云杉-灌木-草本常绿针叶林

Picea schrenkiana - Shrub - Herb Evergreen Needleleaf Forest

- 栓皮柇十麻柇-灌木-草本落叶阔叶林 Quercus variabilis + Quercus acutissima Shrub - Herb Deciduous Broadleaf Forest

- 虎榛子-草本落叶阔叶灌丛 Ostryopsis davidiana - Herb Deciduous Broadleaf Shrubland

- 红砂-草本 半灌木与草本荒漠

Reaumuria songarica - Herb Semi-Shrub and Herb Desert

\section{- 大针茅-草本 丛生草类草地}

Stipa grandis - Herb Tussock Grassland

\section{6 群丛的命名}

群丛的名称是由群落的建群种以及除优势层以 外的其他各个层的特征种(或优势种)名称外加限定 词组成。一般地, 在群丛组名称的基础上, 根据分类 的结果, 把各个群落层的生活型的名称替换成具体 的植物名称, 就构成了一个群丛的名称。

在一个群丛组内, 各个群丛的建群种或优势种 相同, 群落的垂直分层结构完全一致, 但是在除了 优势层或层片或次优势层(适用于森林群落)以外的 其他群落层中, 至少有一个层的特征种不同, 这是 群丛组内植被类型多样化的基础。在群丛命名时, 各个层的植物名称选择的优先次序是: 优势种 + 常 见种+特征种, 优势种+特征种, 常见种+特征种, 特 征种, 优势种, 常见种。如果仅有特征种一个选项, 就要选择特征值较高的物种作为命名物种。如果同 时满足上述某一组条件的物种多于 1 个, 可以按照 物种的平均盖度进行排序, 选出具有最大盖度值的 物种作为命名物种; 如果盖度数据缺乏, 可按平均 高度进行递减排序, 选出平均高度最大的物种作为 命名物种。在 1 个群从组内仅有 1 个群丛的特殊情况 下, 某些群落层或层片可能缺乏群从尺度上的特征 种, 可选择该层中的优势种或常见种作为群从名称 中该群落层的物种。群丛名称中出现的多个特征种, 可能分别来自群系、亚群系、群丛组和群丛尺度。 例如, “雪岭云杉-水栒子-东北羊角芹 常绿针叶林 Picea schrenkiana - Cotoneaster multiflorus - Aegopodium alpestre Evergreen Needleleaf Forest”是一 个群丛的名称, 其中雪岭云杉、水栒子和东北羊角 芹分别是群系、群丛组和群丛水平上的特征种。对 于特定群落层中暂时不能准确鉴定, 但是又具有较 高特征值的物种, 其不确定的名称形式也可出现在 群丛名称中。例如, 一些林下的薹草类植物常是草 本层的优势类型, 但长期处在营养生长阶段, 鉴定 困难。在群丛的名称中, 可以使用“Carex spp.”或 “Carex sp.”等不确定的名称。在后续修订中, 可以用 确定的名称替换原来的不确定的名称, 并加以说明。

随着样方数量的积累, 借助数量分类的修订结 果可能会改变群从原始描述中各个物种的属性。例 如, 在一个群丛的原始描述中, 一个物种具有“优势 种+特征种”或“常见种+特征种”的属性, 其名称已 
经被用于该群丛的命名; 在后续的修订中, 其属性 可能发生了变化, 但是只要仍然是特征种、优势种 或常见种，修订后的群丛中仍然有 $50 \%$ 以上的特征 种与原始描述相同, 就应沿用原始描述的群丛名称, 群丛的描述可以根据修订的结果进行充实和完善。 植被分类单位的名称虽然具有反映群落组成和结构 的主要功能, 但也具有一定的符号属性。因此, 在修 订过程中, 应避免因物种属性的某些变化而随意改 变群从名称的做法。群丛的名称中, 1 个群落层中只 选择 1 个植物名称, 1 个群从名称中植物拉丁名总数 一般不超过 5 个。

同样地, 群丛的科学名称后一般不加限定词 “Association”, 因为其名称本身具有明显的区别特 征, 即出现了表征群落各个层的优势种或特征种的 名称。在一些特殊情形下, 例如群系、群从组和群 从三者的名称完全一致, 则在科学名称后附加各自 的限定词。

群从命名举例:

- 雪岭云杉-水栒子-东北羊角芹常绿针叶林 Picea schrenkiana - Cotoneaster multiflorus Aegopodium alpestre Evergreen Needleleaf Forest

- 栓皮柇+麻栋-南方六道木-黄背草 落叶阔叶林 Quercus variabilis + Quercus acutissima Zabelia dielsii - Themeda triandra Deciduous Broadleaf Forest

- 虎榛子-大披针薹草落叶阔叶灌丛 Ostryopsis davidiana - Carex lanceolata Deciduous Broadleaf Shrubland

- 红砂-绵刺 半灌木与草本荒漠

Reaumuria songarica - Potaninia mongolica Semi-Shrub and Herb Desert

- 大针茅-粘隐子草 丛生草类草地 Stipa grandis - Cleistogenes squarrosa Tussock Grassland

中国植被命名法规增加了植被名称中的信息量, 最突出的特征是在群从组和群丛的名称中展示了群 落的分层信息。在野外植被调查中, 根据群落结构 和物种组成, 就可以初步确定所调查的植被类型和 名称。而且, 群系、群从组和群丛的名称仅从名称 的结构上就可加以识别。群系的名称只包含建群种 或共建种, 不包含群落分层信息, 科学名称以限定
词“Alliance”结尾; 群丛组的名称中，除了包含建群 种或共建种外, 还包含群落分层信息, 后者以各层 的生活型名称显示; 群丛名称中除了包含建群种或 共建种外，群落分层信息是以各层的优势种或特征 种的名称表达。

\section{7 植被类型的编码规范}

每个群系、群丛组和群从均有唯一的系统编码, 用于植被分类单元的标识、信息存咜和检索等。

群系的编码由群系科学名称中植物拉丁名中的 2-3个字母组成。如果群系科学名称中包含的植物名 称多于 1 个, 则以首个植物名称作为编码的依据。

属名的首个字母与种加词首个字母的组合是首 选的群系编码。例如, 麦吊云杉林(Picea brachytyla Mixed Needleleaf and Broadleaf Forest Alliance)的系 统编码是PB。如果出现重复, 在编码中则使用“属名 首个字母+种加词中任意 1 个或 2 个字母”的组合或 “属名前 2 个字母+种加词中任意 1 个字母”的组合。例 如, 白扦林(Picea meyeri Forest Alliance)和台湾云杉 林(Picea morrisonicola Forest Alliance)的系统编码 分别是PME和PMO。群系编码中包含的字母数一般 不超过 3 个。

群从组的编码由其所在群系的编码与罗马数字 组成, 中间加连字符“-”; 群丛的编码由其所在群系 的编码与阿拉伯数字组成, 中间加连字符“-”。在一 个群系内, 群从组与群丛均进行系统编号, 亦即无 论是罗马数字还是阿拉伯数字在一个群系的编码系 统中均只出现一次。基于这样的编码原则, 从编码 本身即可识别出群丛组和群丛在群系中的排序位置, 显示了群系与群丛组和群丛间的隶属关系。以白扞 林为例, PME-I和PME-II分别是白扞林中第 1 个和第 2 个群丛组的编码; PME-1和PME-2分别是白扞林中 的第 1 个和第 2 个群丛。

\section{8 植被命名和编码的优先原则}

在《中国植被志》研编及后续的修订过程中, 植 被名称及其编码的选用应遵循优先原则, 新的名称 或编码不能与已经在《中国植被志》正式发表的植 被名称及其编码相同。新的植被名称及其编码在使 用前, 首先要进入中国植被志工作网站(http://vegetation.ibcas.ac.cn)的“查询系统”中查询或查重。

由于植物群落结构和物种组成所具有的动态特 征，可能会出现一个群丛组或群丛属于不同群系的 情况, 这是植被分类与植物分类最重要的一个区 
别。例如, 云杉林和川西云杉林是 2 个独立的群系, 在群落的交汇地带, 可能出现云杉与川西云杉的混 交林, 但是其地理分布范围狭窄, 群落数量较少。从 植被分类的科学性原则出发, 这样的植被类型或许 应该划分为新的群系, 这样一来群系等级上的分类 单位将过于琐碎。因此, 在植被分类过程中, 这样的 植被类型一般作为群系下的分类单位(亚群系或群 丛组)进行处理, 其名称可分别出现在云杉林和川 西云杉林中, 为了避免出现重复描述和同物异名的 现象, 这个植被类型的名称、编码、植被特征的描 述必须是唯一的, 可完整地出现在志书编排体系中 较靠前的一个群系中(例如, 置于云杉林中, 适用于 云杉占优势或云杉与川西云杉的优势度相当的群落 类型), 而在靠后的另一个群系中(例如, 川西云杉 林), 为了保持其分类系统的完整性, 也可引用这个 植被类型, 但要使用同一个植被名称和编码, 群落 的描述部分使用“参见XX章XX节”即可。在云杉和 川西云杉的混交林中, 如果后者的优势度大于前者, 虽然云杉林群系在志书编排体系中较靠前, 但这样 的混交林则应该置于川西云杉林群系中进行分类和 描述。对于群落结构和物种组成更为复杂的植被类 型, 例如分布于亚热带和热带地区的森林植被, 群 系水平上的划分必须借助数量分类方法, 篎选出一 组特征种对群落加以划分。对于地理分布范围狭窄、 处在群落交汇处的特殊类型, 可参照以上方法进行 分类、描述和命名。云杉、冷杉等常绿针叶树与落 叶松等落叶针叶树组成的落叶与常绿针叶混交林, 在中国东北、西北、华北及西南山地的中海拔和高 海拔地带均有分布, 在中国植被分类系统中属于一 个独立的植被型, 将作为独立卷册进行描述(方精 云等, 2020; 郭柯等, 2020), 其中涉及的植被类型名 称如果在相关卷册中已经被使用, 应遵从优先原则。

\section{6 植被分类单元描述的内容与规范}

中国植被分类系统包括了高级(植被型组、植被 型、植被亚型)、中级(群系组、群系、亚群系)和低 级(群丛组、群丛)植被分类单位(中国植被编辑委员 会, 1980; 方精云等, 2020; 郭柯等, 2020)。在《中国 植被志》植被类型划分及编排体系中, 植被志的每 一卷对应一个植被型, 而每一册是按“植被类型”划 分的, 多数情况下对应一个群系组, 也可能对应一 个植被亚型(方精云等, 2020)。在《中国植被志》的
一册中, 通常以群系为单元划分出若干章。每章描 述的内容包括地理分布、自然环境、生态特征、物 种组成和群落结构、群丛组和群丛的分类与描述、 优势种的生物学特性、生物量与生产力、植被动态 与演替以及价值与保育等。其中重点内容之一是“群 从组、群从的分类与描述”, 主要对群系以下的分类 单位(群从组和群从)进行分类和描述。

综上可见, 《中国植被志》的各卷册所描述的 对象主要是中国植被分类系统的中级和低级分类单 位; 而中国植被高级分类单位基本特征的归纳与总 结, 将在《中国植被志》全部的卷册研编完成的基 础上，以《中国植被志》总论的形式呈现。

植被分类单位描述的内容通常包括地理分布, 自然环境, 群落外貌、结构、物种组成, 植被动态, 价值与保育等方面。但是, 不同的植被分类单位其 描述的侧重点不同。群系、群从组和群丛描述的体 裁与规范将在下节中详细叙述, 这里就各分类单位 描述中的一些共性问题进行阐述。

植被高级分类单位(植被型组、植被型和植被亚 型)的描述具有高度概括的性质, 主要在中国植被 分类系统的中级和低级分类单位分类和描述的基础 上, 重点对该植被类型在全球和中国境内的地理分 布、自然环境、群落外貌、植被类型、生物多样性 保育价值，包括珍稀动植物资源和栖息的旗舰动物， 以及资源现状等进行概述。对涉及中国植被类型多 样性的内容, 应具体说明植被现状, 呈现所包含的 植被分类单元的数量。例如, 就特定植被型而言, 应 说明其在中国境内所包含的植被亚型、群系组、群 系、亚群系、群从组和群丛的数目。中国植被高级 分类单位基本特征是基于实证资料所进行的归纳和 总结, 是对《中国植被》(中国植被编辑委员会, 1980) 相关内容的修订和拓展, 将是对中国植被基本特征 最权威、最准确的记述。

中国植被分类系统中级和低级分类单位的描述 是植被志各卷册研编的主要内容; 描述工作是在文 献整编、群落调查和数据分析的基础上进行的。中 级分类单位(群系组和群系)的描述兼有归纳概括和 细节描述特点, 而群从组和群从的描述主要是基于 样方数据的详细描述。群系组的描述一般编排在植 被志每一册的前两章, 描述的内容及格式与高级分 类单位类似; 群系及以下分类单位的描述是在数据 分析的基础上的具体阐述, 但是也包括对一些基本 
特征或规律性内容的归纳, 每一章各部分的描述内 容、撰写体裁和相关规范详见附件I。

群丛的描述最为细致而具体, 下面以一个森林 群从为例说明其描述内容和规范, 其他植被类型群 从可仿照此格式进行相关描述。对森林群丛而言, 一般要根据群落的分层特征, 自上而下对其结构、 组成、地理分布和生境等进行详细描述。

乔木层的描述内容包括盖度、胸径和高度的变 化幅度。例如，一个群丛“乔木层的盖度60\% 70\%, 胸径（8）39 44（66） cm, 高度（7）28２9（37） $\mathrm{m}$ ”, 说明在这个群丛的凭证样方中, 最小盖度 $60 \%$, 最大盖度 $70 \%$; 个体的最小胸径 $8 \mathrm{~cm}$, 最大胸径 $66 \mathrm{~cm}$, 在样方尺度上的最小平均胸径 $39 \mathrm{~cm}$, 最大 平均胸径 $44 \mathrm{~cm}$; 个体的最小树高 $7 \mathrm{~m}$, 最大树高 $37 \mathrm{~m}$, 在样方尺度上最小平均树高 $28 \mathrm{~m}$, 最大平均 树高 $29 \mathrm{~m}$; 在分层描述中, 一般不再对这些特征进 行复述。乔木层通常划分为大乔木层、中乔木层和 小乔木层 3 个亚层。在分层描述中, 除了列举各个亚 层的常见种、优势种和偶见种外, 还对物种的生长 状况和外貌特征等进行描述; 在乔木层中出现的大 型灌木、附生植物和藤本植物要统计为该层的物种, 并进行相应的描述。在数据可用的情况下, 对群落 建群种的种群结构(径级和树高)特征进行归纳并图 示。

灌木层描述的内容包括总盖度和高度, 数据的 展示方式同乔木层。灌木层可划分为大灌木层、中 灌木层和小灌木层。应分层列举优势种、常见种和 偶见种, 包括出现在各亚层中的乔木树种的幼苗和 蔓生藤本植物, 物种的生长状况、生长型、生境的 偏好和物候特征等。在一些生境中, 个别高大的草 本可进入灌木层, 由于其具有一岁一枯荣的生长习 性, 不能统计为灌木层的物种组成。

草本层应首先描述该层的总盖度和高度范围, 分层列举优势种、常见种和偶见种, 物种的生长状 况、生长型、生境的偏好和物候特征等。根据高度, 草本层可划分为大草本层、中草本层和小草本层; 也可以根据生活型或生长型进一步划分为直立杂草 层、莲座叶草本层、蔓生草本层、根茎和从生禾草 层等。如果出现蔓生的矮半灌木层片, 如西伯利亚 云杉林(Picea obovata Needleleaf Forest)下的北极花 (Linnaea borealis)层片, 也应进行记载和描述。草本 层内的分亚层现象, 是植物对阴暗环境长期适应的
结果, 突出表现在植物生长型、繁殖方式和生活史 周期等方面的变化。在林下的弱光环境中, 一些生 态幅度较宽的植物会长期处在营养生长阶段, 靠无 性生殖维持种群, 一旦光照条件改善, 可开花结实; 另一些植物是弱光环境下的特有种, 在林下可完成 生活史, 光照改善后会被其他物种替代。乔木和灌 木的幼苗如果出现在草本层, 也应统计为草本层的 物种组成, 并进行相关描述。因此, 乔木层的一个物 种, 可能会出现在群落的多个结构层中, 在群落分 类汇总表中也会多次出现, 可以根据群落的分层编 号鉴别出其所属的群落层。

地被层, 也称苔藓层, 成片或斑块状贴地生长 在土层、岩石和枯树干上, 主要由苔藓植物组成, 也 可能出现地衣、藻类和菌类等。描述内容包括盖度、 高度、适生环境、物种组成及其空间分布特征等。

在沼泽和水生植物群落中, 浮水植物层和沉水 植物层是描述的对象。描述的内容包括物种组成、 盖度、密度、在水生环境中的空间分布等。

植被分类单元地理分布范围(水平分布和垂直 分布), 群落环境(地貌、坡度、坡向、坡位、土层厚 度和土壤基质等), 人类活动干扰状况等特征, 主要 依据样方和文献记载的资料进行描述，描述的详细 程度取决于资料的拥有量和代表性。在缺乏系统抽 样资料的情况下, 这部分内容可以概述。

最后, 对群系、群丛组和群丛的分类处理以及 与相近分类单元的关系等, 也应尽可能做出简要的 分析和说明。除了文字描述以外, 还要提供反映群 落环境或景观, 群落外貌和结构, 以及群落各层片 优势种或常见种和各个群丛特征种的照片, 与文本 同步发表。对于群落结构复杂的植被类型(特别是在 群从组尺度上), 应使用墨线图展示群落的垂直或 水平结构。

\section{7 植被志章节编写大纲、体裁及撰写规范}

植被志每一册的前两章是分别在全球和中国的 地理尺度上, 对拟描述植被类型(群系组)的概述和 归纳; 从第3 章起, 通常以群系为单位分章, 对所涉 及的群系类型进行逐一描述。章节编排及主要内容 简述如下(详见附件I)。

第1章: 按照卷册编排体系, 对全球的该植被类 型进行概述, 概述内容包括: 地理分布, 自然环境 (地形地貌、气候(附表2)、土壤等), 植被类型及特 
征, 价值与保育等。

第2章: 按照卷册编排体系, 对中国的该植被类 型进行概述, 概述内容包括: 研究历史回顾, 地理 分布, 自然环境(地形地貌、气候、土壤等), 物种组 成(科属种组成(附表7), 区系成分(附表8)以及生活 型(附表9)), 群落结构, 植被类型及特征, 植被动态 与演替, 价值与保育等。

第3 章及以后各章, 每一章描述一个中级植被 分类单元, 例如群系或群系组, 各章描述的框架和 格式相同。各群系描述的内容包括地理分布, 自然 环境, 生态特征, 物种组成(科属种组成、区系成分、 生活型), 群落结构, 群丛组、群丛的分类与描述, 优势种的生物学特性, 生物量与生产力, 植被动态 与演替, 价值与保育等。其中, “群丛组、群丛的分 类与描述” 是核心内容, 要对群系以下的单位进行 详细的分类与描述; 其他内容是在宏观尺度上对群 系进行概述, 不针对特定的群落。

植被志为说明文体裁, 力求言简意赅, 行文流 畅, 用词准确, 表述规范。对植被分类单元的描述应 客观真实, 条理清唽, 主次分明, 一般不使用比喻 或拟人的修辞方法, 不做夸张的描述。在群落外貌、 结构、物种组成和动态等描述的基础上, 对本质性 或规律性的内容可进行适当的归纳和总结, 对表象 可进行推理性的解释。

\section{8 结语}

《中国植被志》将对包括森林、灌从、草本植 被(草地)、荒漠、高山冻原与稀疏植被、沼泽与水 生植被、农业植被、城市植被和无植被地段在内的 9 个植被型组进行系统描述(方精云等, 2020)。本文提 出了《中国植被志》研编的总体框架和基本原则, 围 绕研编的内容和规范所制定的标准和工作方案, 适 用于绝大多数自然植被类型植被志的研编工作, 包 括森林、灌丛、草本植被(草地)、荒漠、高山冻原 与稀疏植被以及沼泽与水生植被等类型。对于农业 植被、城市植被, 以及无植被地段等少数自然植被 而言, 其植被志研编内容和规范的细则和工作方案 需要在参考本规范的基础上另行制定。

《中国植被志》的研编是中国植被研究中的一 项全新工作。由于中国植被类型十分复杂, 人类活 动对自然植被的干扰较重, 植被现状描述的内涵丰 富, 描述的深度和广度也极不平衡。本文所发布的
植被志研编内容和规范, 尽可能涉及各类植被类型 现状描述的主要内容, 但仍难涵盖全部, 疏漏之处 在所难免。在未来植被志的研编实践中, 需要对本 规范进行进一步的修订和完善。

致谢 感谢众多专家在讨论中国植被志研编规范中 提出的宝贵意见和建议; 《中国植被志》编研办公 室蒋延玲博士在本文写作过程中提供了技术支持。

\section{参考文献}

Bigwood DW, Inouye DW (1988). Spatial pattern analysis of seed banks: an improved method and optimized sampling. Ecology, 69, 497-507.

Breiman L, Friedman JH, Olshen RA, Stone CJ (1984). Classification and Regression Trees. Chapman \& Hall, Monterey.

Ding YH (2013). Climate of China. Science Press, Beijing. [丁 一汇 (2013). 中国气候. 科学出版社, 北京.]

Faber-Langendoen D, Keeler-Wolf T, Meidinger D, Tart D, Hoagland B, Josse C, Navarro G, Ponomarenko S, Saucier J-P, Weakley A, Comer P (2014). EcoVeg: a new approach to vegetation description and classification. Ecological Monographs, 84, 533-561.

Fang JY, Guo K, Wang GH, Tang ZY, Xie ZQ, Shen ZH, Wang RQ, Qiang S, Liang CZ, Da LJ, Yu D (2020). Vegetation classification system and classification of vegetation types used for the compilation of vegetation of China. Chinese Journal of Plant Ecology, 44, 96-110. [方 精云, 郭柯, 王国宏, 唐志尧, 谢宗强, 沈泽吴, 王仁卿, 强胜, 梁存柱, 达良俊, 于丹 (2020). 《中国植被志》的 植被分类系统、植被类型划分及编排体系. 植物生态学 报, 44, 96-110.]

Fang JY, Wang XP, Shen ZH, Tang ZY, He JS, Yu D, Jiang Y, Wang ZH, Zheng CY, Zhu JL, Guo ZD (2009). Methods and protocols for plant community inventory. Biodiversity Science, 17, 533-548. [方精云, 王襄平, 沈泽昊, 唐志尧, 贺金生, 于丹, 江源, 王志恒, 郑成洋, 朱江玲, 郭兆迪 (2009). 植物群落清查的主要内容、方法和技术规范. 生 物多样性, 17, 533-548.]

Federal Geographic Data Committee (2008). National Vegetation Classification Standard. 2nd ed. [2019-10-10]. http:// www.fgdc.gov/standards/projects/FGDC-standards-projects/ vegetation/NVCS_V2_FINAL_2008-02.pdf.

Gong ZT, Huang RJ, Zhang GL (2014). Soil Geography of China. Science Press, Beijing. [龚子同, 黄荣金, 张甘霖 (2014). 中国土壤地理. 科学出版社, 北京.]

Guo K, Fang JY, Wang GH, Tang ZY, Xie ZQ, Shen ZH, Wang RQ, Qiang S, Liang CZ, Da LJ, Yu D (2020). A revised scheme of vegetation classification system of China. Chinese Journal of Plant Ecology, 44, 111-127. [ 郭柯, 方 精云, 王国宏, 唐志尧, 谢宗强, 沈泽昊, 王仁卿, 强胜, 
梁存柱, 达良俊, 于丹 (2020). 中国植被分类系统修订 方案. 植物生态学报, 44, 111-127.]

Jennings MD, Faber-Langendoen D, Loucks OL, Peet RK, Roberts D (2009). Standards for Associations and Alliances of the U.S. National Vegetation Classification. Ecological Monographs, 79, 173-199.

Lin P (1990). Vegetation of Fujian. Fujian Science and Technology Publishing House, Fuzhou. [林鹏 (1990). 福建植 被. 福建科学技术出版社, 福州.]

Ma B, Qiang S, Wei SH (2004). Research method of farmland weed seed bank. Weed Science, (2), 5-8. [马波, 强胜, 魏 守辉 (2004). 农田杂草种子库研究方法. 杂草科学, (2), 5-8.]

Qiang S (2011). Weed Science. 2nd ed. China Agriculture Press, Beijing. [强胜 (2011). 杂草学. 2版. 中国农业出版社, 北京.]

Research Institute of Forestry, Chinese Academy of Forestry Sciences (1986). Forest Soil of China. Science Press, Beijing. [中国林业科学研究院林业研究所 (1986). 中国森 林土壤. 科学出版社, 北京.]

Rodwell JS, Pigott CD, Ratcliffe DA, Malloch AJC, Birks HJB, Proctor MCF, Shimwell DW, Huntley JP, Radford E, Wigginton MJ, Wilkins P (1991). British Plant Communities: Vol. I. Cambridge University Press, Cambridge, UK.

Song YC (2013). Evergreen Broad-leaved Forests in China: Classification-Ecology-Conservation. Science Press, Beijing. [宋永昌 (2013). 中国常绿阔叶林: 分类 - 生态 - 保 育. 科学出版社, 北京.]

Song YC (2017). Vegetation Ecology. 2nd ed. Higher Education Press, Beijing. [宋永昌 (2017). 植被生态学. 2 版. 高等教育出版社, 北京.]

Song YC, Yan ER, Song K (2017). An update of the vegetation classification in China. Chinese Journal of Plant Ecology, 41, 269-278. [宋永昌, 阎恩荣, 宋坤 (2017). 再议中国 的植被分类系统. 植物生态学报, 41, 269-278.]

The Editorial Committee of Natural Geography of China, Chinese Academy of Sciences (1980). Natural Geography of China: Landform. Science Press, Beijing. [中国科学院 《中国自然地理》编辑委员会 (1980). 中国自然地理: 地貌. 科学出版社, 北京.]

The Editorial Committee of Natural Geography of China, Chinese Academy of Sciences (1981). Natural Geography of
China: Soil Geography. Science Press, Beijing. [中国科学 院《中国自然地理》编辑委员会 (1981). 中国自然地理: 土壤地理. 科学出版社, 北京.]

The Editorial Committee of Natural Geography of China, Chinese Academy of Sciences (1984). Natural Geography of China: Climate. Science Press, Beijing. [中国科学院《中 国自然地理》编辑委员会 (1984). 中国自然地理: 气候. 科学出版社, 北京.]

The Editorial Committee of Vegetation Map of China, Chinese Academy of Sciences (2007a). Vegetation Map of the People's Republic of China 1:1 000 000. Geological Publishing House, Beijing. [中国科学院中国植被图编辑委 员会 (2007a). 中华人民共和国植被图1:1000 000. 地 质出版社, 北京.]

The Editorial Committee of Vegetation Map of China, the Chinese Academy of Sciences (2007b). Vegetation of China and Its Geographic Pattern-Illustration of the Vegetation Map of the People's Republic of China (1:1 000 000). Geological Publishing House, Beijing. [中 国科学院中国植被图编辑委员会 (2007b). 中国植被及 其地理格局一一华人民共和国植被图(1:1000 000)说 明书. 地质出版社, 北京.]

The Editorial Committee of Vegetation of China (1980). Vegetation of China. Science Press, Beijing. [中国植被编辑委 员会 (1980). 中国植被. 科学出版社, 北京.]

Thompson K, Bakker JP, Bekker RM (1997). The Soil Seed Banks of North West Europe: Methodology, Density and Longevity. Cambridge University Press, Cambridge, UK.

Tichy L, Holt J (2006). JUICE: program for management, analysis and classification of ecological data. [2019-10-10]. https://www.sci.muni.cz/botany/juice/JC_man1.pdf

Wang GH (2017). Spruce Forest of China. Science Press, Beijing. [王国宏 (2017). 中国云杉林. 科学出版社, 北京.]

Weber HE, Moravec J, Theurillat JP (2000). International Code of Phytosociological Nomenclature. 3rd ed. Journal of Vegetation Science, 11, 739-768.

Whittaker RH (1978). Classification of Plant Communities: Handbook of Vegetation Science. Springer, Berlin.

You LY, Yang JC (2013). Landform of China. Science Press, Beijing. [尤联元, 杨景春 (2013). 中国地貌. 科学出版 社, 北京.]

责任编辑：谢 巍 


\section{附件 Appendix}

156 附件I 《中国植被志》卷册编写大纲及撰写规范

Appendix I An outline and protocls for the compilation of Vegegraphy of China

169 附表1 植物群落调查表

Appendix Table 1 Sample table for plant community survey

175 附表 2 植被类型海拔及气候因子的描述性统计汇总样表

Appendix Table 2 A sample table for the summary of altitude ranges and climatic factors of a vegetation type

175 附表3 样方基本信息表

Appendix Table 3 Plot basic information

176 附表4 样方数据汇总表

Appendix Table 4 A summary for plot data

177 附表5 物种-样方数据表

Appendix Table 5 Species by plot data

177 附表6 植被描述中一些常用的地形、地貌术语的中英文对照及英文缩写

Appendix Table 6 A list of commonly used terms of terrain and landform for the description of vegetation

177 附表7 植被类型植物科属种组成汇总样表

Appendix Table 7 A sample table for the summary of taxonomic composition of a vegetation type

178 附表8＼cjkstart植被类型种子植物区系成分汇总样表

Appendix Table 8 A sample table for the summary of the areal type of seed plant species of a vegetation type

178 附表9 植被类型植物生活型谱汇总样表

Appendix Table 9 A sample table for the summary of life-form spectrum of a vegetation type 
附件I 《中国植被志》卷册编写大纲及撰写规范

Appendix I An outline and protocls for the compilation of Vegegraphy of China

\section{一、《中国植被志》卷册编写大纲}

第 1 章 全球某群系组 (群系组名称, 如云杉林、落叶松林等) 概述

1.1 地理分布

1.2 自然环境

1.2.1 地貌

1.2 .2 气候

1.2 .3 土壤

1.3 植被类型及特征

1.4 价值与保育

第 2 章 中国某群系组 (群系组名称, 如云杉林、落叶松林等) 概述

2.1 研究历史回顾

2.2 地理分布

2.3 自然环境

2.3.1 地貌

2.3.2 气候

2.3 .3 土壤

2.4 物种组成

2.4 .1 科属种

2.4.2 区系成分

2.4 .3 生活型

2.5 群落结构

2.5.1 水平结构 ${ }^{*}$

2.5.2 垂直结构

2.6 植被类型及特征

2.7 植被动态与演替*

2.8 价值与保育

(从第3章起, 各章的编写大纲完全一致。下面仅列出第 3 章的大纲, 其余各章省略。)

第 3 章 群系名称 (如雪岭云杉林、华北落叶松林等)

3.1 地理分布

3.2 自然环境

3.2.1 地貌

3.2 .2 气候

3.2 .3 土壤

3.3 生态特征

3.4 物种组成

3.4.1 科属种

3.4 .2 区系成分

3.4.3 生活型

www.plant-ecology.com 
3.5 群落结构

3.5 .1 水平结构

3.5 .2 垂直结构

3.6 群从组、群丛的分类与描述

3.7 优势种的生物学特性*

3.7.1 遗传特征

3.7 .2 个体生长发育

3.8 生物量与生产力*

3.9 植被动态与演替

3.10 价值与保育

注: 标注*的为自选内容, 其他为规定内容。

\section{二、《中国植被志》撰写规范}

\section{第 1 章 全球（群系组名称，如云杉林、落叶松林等）概述}

在全球尺度上，简要论述拟描述的群系组（植被类型）在科学研究、生产实践和生态保育中的重要性、 特殊性及其意义。可附反映该群系组景观或外貌的照片或图片。

\section{1 地理分布}

\section{1 .1 水平分布}

重点阐述该群系组在全球的地理分布范围, 包括分布区所覆盖的大尺度的地理单元 (东西、南北半球, 洲际尺度）、分布区所跨越的地理或行政区域边界、在各大洲以及在全球的地理坐标范围。全球的地理分 布图在含有投影经纬网、包含世界各大洲界及主要河流的世界地理底图上绘制, 以黑色的圆点或用实线条 勾绘边界, 以表征植被的地理分布区域。地理底图由《中国植被志》编研办公室统一提供。可附反映该群 系组在不同地理单元的景观外貌照片。

\section{1.2 垂直分布}

重点阐述在全球的海拔分布范围及其在区域间的变化，可提供垂直分布范围与经纬度间变化的趋势图。

\subsection{3 起源与散布}

依据古植物学、古地理学以及物种系统发育学等方面的研究成果, 阐述该群系组的建群种或优势种起 源的时间、演化过程和散布途径等。在较短的时间尺度上, 如几十年至数百年, 由于气候变化或人为干扰 导致植被类型的明显变化也应加以记述。对于相关研究资料缺乏的群系组, 此部分可作为自选内容。 


\section{2 自然环境}

\subsection{1 地貌}

阐述在全球分布范围内的主要地貌类型及其区域分异, 地貌类型的基本特征, 包括大尺度的地貌单元 及其组合特征; 阐述地貌变化对植被分布或生长的影响等。可附反映主要地貌类型的景观外貌照片。

\subsection{2 气候}

根据文献资料, 阐述该群系组的气候类型及跨越的气候带, 主要气候指标（如年平均气温、年降水量 以及水热平衡因子等）的变化幅度以及区域分异等。由于在全球范围内进行布点的难度较大，气候特征的 量化描述设定为自选内容, 对气候指标也不作具体限定。对于基础研究较好的植被类型, 鼓励使用技术手 段量化描述植被的气候特征。

\section{2.3 土壤}

简述分布区范围内主要土壤类型、基本特征及其空间分布特点。

对水生植被而言，概述水体类型，水体环境如水温、盐度、酸碱度、浑浊度和水深度等。

\section{3 植被类型及特征}

简要阐述在全球范围内的主要植被类型（群系、群丛组或群丛）的划分及其地理分布、生境、物种组 成和群落结构特征。附反映主要植被类型的景观外貌照片，包括同一植被类型季相变化的照片等。

\section{4 价值与保育}

阐述该群系组在全球的植被资源特征, 主要的生态系统功能, 主要的人为和自然干扰类型及保育对策, 可附相关照片。

以上各部分描述的依据主要来自国内外的文献, 特别要对国外的植被生态学或植被分类文献进行系统 梳理。由于植被基础研究的详细程度在不同的国家或不同的区域间存在差异，各部分描述的详细程度取决 于资料的拥有量。

\section{第 2 章 中国（群系组名称，如云杉林、落叶松林等）概述}

\section{1 研究历史回顾}

阐述该群系组的研究历史。基于由远及近的原则, 系统梳理不同时期的研究特点和主要成果。 


\section{2 地理分布}

\section{2.1 水平分布}

重点阐述该群系组在中国境内的地理分布范围, 包括分布区覆盖的地貌单元 (如高原、山地、平原等), 行政区域（大区域如东北、华北、西北以及各省区等），分布区的地理边界和地理坐标范围等。拟描述的 植被类型的地理分布图应在含有投影经纬网, 包含省界及主要河流的中国地理底图上绘制, 以黑色的圆点 表示植被的分布点, 或用实线勾绘边界。群系组的地理分布图主要根据其所包含的全部群系的地理分布信 息进行绘制, 可在全部群系的地理分布图制作完成后再进行汇总和绘制。可附反映该群系组在不同地理单 元中的植被景观或群落外貌照片。

\section{2.2 垂直分布}

重点阐述该群系组在中国的海拔范围及其在区域间的变化，可以提供垂直分布范围与经纬度间的相关 趋势图。

\section{2.3 起源与散布}

主要依据古植物学、古地理学以及物种系统发育学等方面的研究成果, 阐述该群系组或其中的优势类 群 (种或种下等级) 在中国发生的时间、区域、散布途径等。对于相关研究资料缺乏的群系组, 可作为自 选内容。

\section{3 自然环境}

\section{3.1 地貌}

阐述该群系组在中国分布区范围内的主要地貌类型及其区域分异, 地貌类型的基本特征, 包括大尺度 的地貌单元等; 阐述地貌变化对植被分布或生长的影响等。可附反映主要地貌类型的景观外貌照片。

\section{3.2 气候}

首先说明所跨越或所处的气候带, 简述其相关特征; 然后利用基于样方或样点的气候数据, 对气候特 征进行量化描述（附表2）。对于其他资料或文献中有反映该群系组气候特征的内容, 也尽可能在此阐述或 说明。

\section{3.3 土壤}

简要阐述该群系组在中国分布区范围内的主要土壤类型、空间分布及其基本特征。土壤数据可以引自 文献和土壤数据库（例如: 中国土壤数据库http://www.soil.csdb.cn）。如果在植被调查的同时也进行了土 壤剖面的调查, 并进行了土壤性质的相关分析, 其数据鼓励优先使用。 
对于水生植被, 要论述其水体类型, 水体环境如水温、盐度、酸碱度、浑浊度、水体营养和水深度等。

\section{4 物种组成}

以样方数据为依据, 整理出高等植物名录, 分别统计和描述本节2.4.1 2.4.3中的内容。

\section{4.1 科属种}

植物的科属种的划分及植物中文名和拉丁名主要参考《Flora of China》。列表显示科属种的总数据和 分群系统计的数据, 然后分别以被子植物、裸子植物、蓱类植物和苔藓植物进行统计描述（附表7）。对于 该植被类型中出现的特殊物种, 如特有种、珍稀濒危物种、外来种或入侵种等, 也要特别说明。除了表格 外, 附必要的文字说明。

\section{4.2 区系成分}

参考中国种子植物科、属分布区类型的划分系统（吴征镒，1991；吴征镒等，2003），统计该植被类 型科、属分布区类型，分布区类型编号和中英文名称要与原始文献相一致。以列表和文字说明的形式展示 相关内容（附表8）。

\section{4.3 生活型}

以《中国植被》（中国植被编辑委员会, 1980) 植物生活型划分系统, 统计植物生活型组成（附表9）, 并加以必要的说明。

\section{5 群落结构}

\subsection{1 水平结构}

对于有大样地研究基础的植被类型，可对其水平结构特征进行描述。对于相关研究资料缺乏的植被类 型, 可作为自选内容。

\subsection{2 垂直结构}

重点阐述该群系组中植物群落的垂直结构特征, 包括分层特征, 各层高度范围, 建群种、优势种及其 他物种的组成状况，物候型（常绿/落叶）以及各个垂直层间物种间的关联等。

\section{6 植被类型及特征}

简要描述该群系组植被分类单元划分的主要依据, 所包含的群系、群从组和群从的数量等。对于群系 www.plant-ecology.com 
组内的群系、群丛组和群从划分及其命名中存在的特殊性, 也需要在此加以说明。

\section{7 植被动态与演替}

简要阐述群系组尺度上植被的发生、发展和演替过程的基本特征。对于人工植被, 也要简述其群落发 展过程及演替的方向。对于相关研究资料缺乏的植被类型，可作为自选内容。

\section{8 价值与保育}

阐述在中国的资源现状, 主要的生态系统功能（如供给、调节、文化及支持等方面的服务功能）, 干 扰类型及保育对策，可附相关照片。

第3 章及以后各章, 每一章描述一个中级植被分类单元, 例如群系或群系组, 各章描述的格式和框架相 同。

\section{第 3 章 群系名称}

系统编码: 群系的系统编码。

名称引证：系统梳理该群系在以往文献中的名称及出处。

下面以“鱼鳞云杉林”为例，说明其章节结构及描述的内容。

\section{第 3 章＼cjkstart鱼鳞云杉林Picea jezoensis var. microsperma Forest Alliance}

系统编码: PJ

鱼鳞云杉、臭冷杉林一一中国植被, 1980: 202-203; 植物生态学与地植物学丛刊, 1964, 2( 2 ): 216-217; 鱼鳞云杉林一一国森林：第2卷 针叶林，1999：691-698; 中国大兴安岭植被，1991：80-84; 鱼鳞云杉、 臭冷杉、红皮云杉林一一中国小兴安岭植被, 1994: 54-91; 云冷杉林一一吉林森林, 1988: 179-193; 云杉、 冷杉林, 红松、云杉、冷杉林一一植物生态学与地植物学丛刊, 1964, 2 (2): 190-206; Abieti nephrolepidisPiceetalia jezoensis—Vegetation, 1992, 98 ( 2): 175-186。

\section{1 地理分布}

简要阐述该群系在中国植被分区系统（中国科学院中国植被图编辑委员会，2007）中的归属或位置及 其成因。

\section{1.1 水平分布}

重点阐述该群系在中国的地理分布范围, 包括分布区覆盖的地理单元 (如高原、山地、平原等), 东西 
南北边界, 地理坐标范围和跨越的行政区域 (省、自治区、直辖市, 市, 县) 等。尽可能附植被类型在不 同区域的景观外貌照片。

群系地理分布图的绘制主要依据野外调查资料（样方记录、路线考察记录等）和植被图及其他相关的 文献资料; 对于资料空缺的区域, 应借助数字地球系统（如Google Earth）或其他大比例尺卫星地图, 由野 外工作经验丰富的植被专家进行判断, 确定出这些区域中特定群系的植被斑块, 视斑块的大小以一定的精 度 $\left(0.1^{\circ} \times 0.1^{\circ}\right)$ 标定样点并获取其地理坐标。对于孤立且面积较小的群系斑块, 一般也应标定 1 个样点; 对于连片分布的群系斑块一般以均匀分布的样点 $\left(0.1^{\circ} \times 0.1^{\circ}\right)$ 或用图斑表示（参见本节 2.2 的方法）。在 小比例尺地理底图上绘制群系的地理分布图, 基于野外调查资料获取的样点间可能重叠较多, 这些样点在 图中原样呈现。群系的地理分布图应在中国地图 (参见本节 2.2 ) 上绘制, 以黑色的圆点表示群系的地理分 布样点, 特别要注重群系地理分布边界地带的样点或图斑的标定与勾绘。

群系的地理分布图也可以由群系斑块的局部放大图与中国地图全图嵌套而成, 以显示群系斑块样点清 晰的地理分布范围。在中国地图中的位置一般叠放在局部放大图左上方的空白区域。群系斑块局部放大图 的宽度一般与页面等宽, 其高度视群系的地理分布斑块的形状而定, 但是在制作局部放大图的过程中不能 改变原图中的长宽比例。在群系地理分布的局部放大图中, 群系斑块的显示比例要适中, 且美观清晰; 群 系地理分布最边界地带的样点或图斑一般要与图的边框有 $2^{\circ}$ (纬度或经度) 左右的间隔。嵌套图的结构复 杂, 可变因素较多, 审图程序严格, 可选择使用。

\section{1.2 垂直分布}

重点阐述该群系的海拔分布范围，以及海拔分布范围在区域间的变化。

\section{2 自然环境}

\section{2.1 地貌}

阐述在中国分布区范围内的主要地貌类型及其区域分异, 地貌类型的基本特征, 包括大尺度的地貌单 元等; 阐述地貌变化对植被分布或生长的影响等; 适宜生长生境, 如果是山地则说明生长的主要坡向和坡 位等。可附反映主要地貌类型的景观外貌照片。

\section{2.2 气候}

描述格式参见本节2.3.2

\section{2.3 土壤}

简要阐述该群系在中国分布区范围内的主要土壤类型及其基本特征。包括土壤垂直结构、各层厚度、 各层物理化学性质等。数据可来自文献或土壤剖面实际调查数据。可附相关照片。

水体环境因子, 包括水的流动性、水温、盐度、水体营养和水深度等, 可根据资料或实际调查数据, 进行定量或定性论述。 


\section{3 生态特征}

通过文献整理、数据分析等手段, 对植被的生境特点, 植被分布的环境解释以及与其他相关植被类型 生态适应性的差异等进行阐述和比较分析。

\section{4 物种组成}

\section{4.1 科属种}

基于该群系收集到的样方数据所整理出的物种名录, 分析科属种组成, 以所包含物种数为依据, 对科、 属进行递减排序, 确定对该群系的群落外貌、结构和物种组成具有重要作用的植物类群（科、属）, 可附 优势种或常见种的照片。

\subsection{2 区系成分}

描述方法参见本节2.4.2。

\section{4.3 生活型}

上述植物名录按照《中国植被》（中国植被编辑委员会，1980）生活型划分系统，统计植物生活型组 成（附表9）, 对植物生活型的基本特征进行描述, 重点说明各个植物生活型对植被类型的多样性, 群落的 外貌、结构等方面的相对重要性。

\section{5 群落结构}

\section{5.1 水平结构}

一般要提供典型群落优势层的个体在水平空间的散布图, 以反映其在样方中的水平分布格局。通常以 实际调查的典型样方为目标群落, 水平空间散布图所涉及的空间范围以及图形的长宽比例应与实际调查的 样方相一致。一般用不同的图形或数字与图形的组合标识不同的植物种, 图注中列出对应的植物名称 (中 拉对照)。森林群落的水平空间散布图应尽可能反映出不同胸径级个体的水平分布格局。

基于样方数据和文献, 对群落中的不同物种, 以及同一个物种不同发育阶段的个体在水平空间的散布 格局也尽可能地进行描述。由于物种水平分布数据的详细程度在不同的样方记录间差别较大, 这部分描述 内容的详细程度可具有一定的弹性。随着植被固定大样地研究工作的不断积累, 相关描述将会不断补充和 更新。对于已经有大样地研究基础的植被类型或群系类型, 应尽可能收集并反映最新的研究成果。

\subsection{2 垂直结构}

植物群落垂直分层结构的完整程度和变异与植被类型、环境条件和人类活动干扰状况密切相关。这部 分的描述主要基于样方数据和文献, 根据群落建群种和优势种的生活型, 群落的垂直分层, 各层的高度范 
围、物种组成等, 在群系尺度上阐述植物群落的外貌、结构、组成以及时空变异特征, 一般要求附反映群 系垂直结构的照片及墨线图。森林群落优势种的结构特征, 如胸径和树高的分布特征可通过频数分布图表 达。群系内不同植物群落的分层特征, 是进一步划分亚群系和群丛组的重要依据。

群落的垂直剖面图应反映一个群落的垂直分层结构和各层优势种的外貌特征。用数字标注图中出现的 每一种植物, 图注中列出对应的植物名称 (中拉对照)。剖面图通常以实际调查的样方为目标群落, 沿样方 的一个边长向样方内推移一定的距离而形成一个窄带, 描绘其中的群落结构和优势种的外貌。群落窄带的 长边与样方的该边长相等, 短边一般在森林群落中不小于 $3 \mathrm{~m}$, 灌从群落中不小于 $1 \mathrm{~m}$, 草地群落中不小于 $10 \mathrm{~cm}$ 。剖面图所反映的是这个窄带中各个物种在一个垂直平面上的投影图, 不必绘成立体图。群落中各个 层的高度与样方边长的比例要与实际群落的特征相一致。墨线图一般用黑白线条绘制。在确保清晰、准确 的前提下, 也可绘制成彩图。剖面图的绘制, 一般由编著者提供墨线草图和必要的照片, 再由专业绘图人 员清绘成图。

群落的垂直剖面图不对物种形态的细节进行刻画, 也不可能显示大量的物种, 仅作为群从组尺度上群 落外貌鉴定的参考凭证。因此, 一般要求一个群丛组有一幅群落垂直剖面图, 对群从不做相应的要求。对 于群落结构简单的植被类型, 如寒温性针叶林、荒漠等, 如果群落照片可清晰地反映出群落的结构和物种 的外貌特征, 可用照片代替墨线图。

对于一些研究资料丰富的植被类型, 可图示或描述群落结构在时间尺度上的变化规律。

\section{6 群从组、群丛的分类与描述}

采用统一的方法和规范对群丛组和群从进行分类、命名与编码, 逐一列出群落分类简表 (表1)、环境 和群落结构信息表 (表2), 以及植被分类检索表 (方框 2 )。在此基础上, 对各个群从组和群从进行详细描述。

\section{6.1 群丛组的描述规范}

在一个群系内, 群从组主要依据群落的分层特征进行划分。在群从组分类简表（表1, 示例表 $3.7 \mathrm{a}$ ) 中 列出特征种及其频度或特征值, 在群从组描述的正文前不再列出特征种和常见种或凭证样方, 这些信息在 群从的描述中详细列举。群丛组的描述具有概括和归纳性质, 从群落的外貌、结构、环境异质性等方面概 述群从组的基本特征以及群落类型多样性的大背景。正文中的植物名称用中文名, 对应的拉丁名在群落分 类简表中必须出现。具体包括以下几个方面:

系统编码

中文名称, 科学名称

名称的文献追溯（在文献中已经出现的类似名称及其出处）

描述正文: 侧重群落外貌、群落的结构、优势层片的生活型特征及其在空间或在环境梯度上的变化规 律、地理分布范围、生境特征、资源状况、干扰状况等。此外, 对群丛组的分类处理、关键识别特征以及 与相近群从组的关系等, 也尽可能做出简要的比较、分析和说明。

附反映群落垂直结构的墨线图或照片。在印刷版中, 通常只保留墨线图和具有代表性的彩色照片; 在 电子版 (网络版) 中, 墨线图和彩色照片均可保留, 在保证质量的前提下, 彩色照片的使用量不受限制。

\section{6. 2 群丛的描述规范}

群丛是根据群落中各个垂直分层或层片的物种组成进行划分的。在群丛分类简表（表1，示例表3.7b） 
中, 不仅列出了群从中出现的全部物种, 还标识出了一组特征种。在文字描述中, 首先单列出各个群丛的 凭证样方名称、特征种和常见种; 在后续的描述中, 除了突出各个层或层片的优势种外, 还应尽可能地列 举出群从中的偶见种。偶见种的生态幅度较狭窄, 只出现在特定的生境中, 其数量可以表征一个群丛的生 境多样性。

在群从特征的描述中, 除了列举出不同属性的物种外, 还需要对各个层或层片中物种的生长状况、生 长型、生境的偏好、物候特征等进行描述, 这些特征的描述是研编工作中的困难环节。因为一般的历史样 方数据对相关特征的记载非常有限, 所以需要大量的野外观测记录支撑。因此, 在植被志书的研编中, 除 了收集以往积累的样方数据和资料外, 还需要进行较为系统的野外调查。

由于在群从描述的正文前已经列举了特征种和常见种, 群落各层描述的重点是群落的结构和各个层的 优势种、偶见种, 一般不再单独罗列特征种和常见种, 以免重复。如果有些特征种或常见种同时也是优势 种, 或者出现在群落中特定的层或层片中, 这些物种还是需要列举和描述。群从描述的内容具体包括以下 几个方面:

系统编码

中文名称, 科学名称

名称的文献追溯（在文献中出现的类似名称及其出处。如果没有，则无此项）

凭证样方: 列举所有的凭证样方。

特征种: 中文名和拉丁名对照, 后者置于括号内, 简写格式, 斜体排版。对于同时具有特征种和常见 种属性的物种, 用“*”标识。

常见种: 中文名和拉丁名对照, 后者置于括号内, 简写格式, 斜体排版。对于同时具有特征种和常见 种属性的物种, 由于已经在上述特征种名录中出现, 在常见种名录中将不再列出, 只在常见种名录后添加“及 上述标注*的特征种”的结尾句。

描述正文: 重点描述群落各个层或层片的结构及数量特征、物种组成、生长状况、地理分布范围、生 境特征、资源状况和干扰状况等。此外, 对群从的分类处理、关键识别特征以及与相近群丛的关系等, 也 要做出简要的比较、分析和说明。

\section{7 优势种的生物学特性}

对建群种或优势种的形态、功能性状、遗传多样性和个体生长发育规律（种子萌发、个体生长过程） 等进行描述。这部分内容是对已有成果的集成和分析, 描述的详细程度取决于相关研究的深度和广度。

\section{8 生物量与生产力*}

在群落或种群 (建群种、优势种) 尺度上, 基于样方数据和文献, 简要阐述生物量和生产力的基本特 征。这部分内容是对已有成果的集成和分析, 由于不同群系间相关研究成果的详细程度不平衡, 描述的内 容和形式没有统一的格式和要求。

\section{9 植被动态与演替}

植被动态和演替特征是反映群落在生长过程中的变化规律, 这些特征的阐述需要不同时间尺度上的调 
查资料支持。在环境条件相对一致的群落间，也可以采用空间系列代替时间系列的方法对植被动态进行描 述。除了长期定位观测样地外, 在许多植被类型中, 不同时间尺度上群落特征的资料较少。因此, 各个群 系植被动态描述的详细程度可能不一致。

\subsection{0 价值与保育}

阐述群系在生态功能、环境保护、生物多样性保育、经济发展等方面的价值, 以及资源现状、干扰类 型、植被恢复进展以及保育对策等, 可附相关照片。

\section{三、《中国植被志》图表文字编辑规范}

\section{1 插图}

插图包括图片、图中的文字和图题。

所有图件应提供可供修改的高分辨率原文件, 文字另层叠放, 以便排版修改。正文中要标识出图片拟 放置的位置。从印刷品、照片上进行扫描, 要求原图清晰, 纯线条图要求 $600 \mathrm{dpi}$ 的分辨率按 $1 \mathrm{bit}$ (黑白方 式）的.tif、.bmp格式; 数字照片要求1 200 万以上像素。

图中的说明文字用6号 “宋体+Times New Roman” 显示, 用文本框置入图中合适的位置。图中的文字、 数值、符号以及正斜体写法等必须与正文、表格、索引中对应的部分相一致。

图题由图号和图题文组成。图题居中放在插图的正下方, 用小 5 号 “宋体+Times New Roman”。图号采 用分章排序，即齐底线的黑圆点 “.”前面为章号，后面为图的顺序号。例如，“图17.39, Figure 17.39”, 表示第17章中的第39幅图, 图号与图题文之间空一个汉字的宽度, 如 “图12.7 白华林的外貌”。在电子版 (网络版) 的图书中, 反映群落外貌和结构的彩色图片的使用不受限制; 在印刷版的图书中, 只使用必要 的黑白图或彩图。图题文应该准确反映插图拟说明的内容, 其后紧跟对插图著作权的说明, 如 “图8.6 红 树林的外貌 (李某某拍摄, 或引自某某某, 1990)”。如果一卷或一册中主要由一个人拍摄, 可在前言中加 以统一说明, 不必在每一幅图题后一一注明拍摄者。

当图元过多而不便用文字注释时, 可使用图元代号或代码 (外文字母和数字等), 图元代号所表征的内 容 (图注) 用6号 “宋体+Times New Roman”排在图题的正下方。

地图应使用中华人民共和国自然资源部网上政务服务平台提供的最新电子版地理底图, 对地图内容编 辑 (包括放大、缩小、裁切、描点、勾绘) 改动的, 公开使用前必须报送有审核权的测绘地理信息行政主 管部门审核, 审核通过后方能使用。

\section{2 表格}

表格按章编号, 与图号要求一致, 例如第 5 章第 2 表, 表编号为 “表 5.2 , Table 5.2 ”, 以此类推。表格宽 度与版心同宽, 表格的基本格式为三线表, 但是根据表格内容的复杂程度, 可加辅助线。表格横向内容太 多，可排成卧排表。

表序、表题文字排小 5 号 “黑体+Times New Roman”, 置于表上居中。表内文字、表注排6号 “宋体+Times New Roman”, 置于表下, 左对齐。表格中的数据和提法应与正文相一致。表题、表中文字的内容和表注 附中英文对照。

\section{3 名称}

中国地名以最新出版的《中华人民共和国分省地图集》《中华人民共和国行政区划简册》和《中国地名 录》为准; 外国地名按商务印书馆出版的《外国地名译名手册》译出, 同一地名译法全书须一致。只讨论 中国的内容, 中国地名前可不冠以 “中国” 字样; 如果同时有外国的内容, 应加上 “中国” 字样。外国地 
名首次出现时, 应冠以国名。行文中,一律用第三人称撰写, 文中不出现 “我国” “我省” “我市” “我院” “我 所”等字样。

学术著作中的外国人名可保留原文。机构名称用最新名称的全称，不使用简称或别名。

植物名称 (中文名, 拉丁名) 以《Flora of China》为主要参考资料。植物拉丁属名、种加词和种下加 词用斜体排版。正文中植物中文名后无需附拉丁名; 表格中, 以及单独列出的物种名录（如文中的特征种 名录)，植物名称应包含中文名和拉丁名。

\section{4 年代}

世纪、年代、年份、月、日用阿拉伯数字表示。例如：19世纪、20世纪80年代、1953年、1979年6月8 日。年代起止用波纹起止号 ( ) 表示, 如1937 1945年、5 11世纪; 非历法年的专用年度起止用一字线 （一）表示，如1980-1981年度。星期几一律用汉字，如星期六。

公元前的世纪、年份应加 “公元前” 字样。例如: 公元前21世纪、公元前209年。表示起止、两个连用 时, 后一个不加 “公元” 字样。例如: 公元前221 前206年、公元前21～前16世纪。在同一条目中多次出现, 一般仅第一次需加 “公元”二字。

公元后的世纪、年份等一般不加 “公元” 字样。例如：11世纪中叶、1969年、1893 1976年。但100 以内的年份除外，例如公元3年、公元25年。

\section{5 数字}

遵从国家标准GB/T 15838-2011《出版物上数字用法的规定》, 另根据实际需要做少量补充和调整。

一般表示数量的数字:

万以下的直接写出。例如: $10 、 432 、 2650$ 等。

大的数字可以万和亿为单位。例如: 3 万、 6.5 万、 50 万、 400 万 (不写作 4 百万) 、 2000 万 (不写作 2 千 万) 、 1 亿、 1.5 亿 (不写作 1 亿 5000 万)、 20 亿、 100 亿（不写作 1 百亿) 等。精确数字全部写出, 例如: “占 地135 $482 \mathrm{~m}^{2}$ ”, “共计12 654株个体”, 其中的数字分节符在Word中采用不间断空格（Ctrl+Shift+Space） 可避免数值断开移行。表达数量性质的数字用阿拉伯数字, 例如 “ 1 个群落层中只选择 1 个物种, 植物拉丁 名总数一般不超过 5 个” 等。如果 “一个” 具有类似于英文冠词性质, 数量属性不明显, 则用汉字, 例如 “在 一个群从的原始描述中，一个物种同时具有优势种和特征种，或常见种和特征种的属性”等。

分数、百分数、比例等用阿拉伯数字表示, 如: $2 / 5 、 25 \% 、 3: 1 、 129: 31$ 等; 但在无精确统计意义时也 可用汉字表示，例如三分之一、千分之一、万分之一等可用汉字表示。

注码、图号、引文出处、参考书目的版次、卷次、页码等用阿拉伯数字。遇特殊情况, 应力求局部统一。

次第用阿拉伯数字。例如: 第3行、第43届。

约数用阿拉伯数字表示。例如: 500 多、1 200左右、约 3 万人等。但带有 “几” 字的约数则用汉字。例 如: 几十岁、一百几十次、几十万分之一。

表示数值范围时, 起止号一律用 “ ”; 起止号前后的数值应完整, 如 1 万 1.5 万年不应写成 $1 \sim 1.5$ 万 年, $20 \% \sim 70 \%$ 不应写成 $20 \sim 70 \%$; 度数范围 $5^{\circ} \sim 40^{\circ}$, 不应写成 $5 \sim 40$ 等。但是, 表示长度、面积、体积、 质量、温度的单位, 只在后面的数值加单位符号, 例如: $3072 \sim 3507 \mathrm{~m}, 600 \sim 800 \mathrm{~mm}, 20 \sim 30{ }^{\circ} \mathrm{C}, 13 \sim$ $15 \mathrm{~g} / \mathrm{kg}$ 等。

气候数据、海拔范围、坡度、坡向、群落的高度和盖度等数据, 数值一般保留整数。土壤化学分析数 据、生产力、光合呼吸等通过观测分析得出的数据, 可保留小数点后两位。

数值的修约遵从 $\mathrm{GB} / \mathrm{T} 8170-2008$ 《数值修约规则与极限数值的表示和判定》, 进舍规则如下: “拟舍 弃数字的最左一位数字小于 5 , 则舍去, 保留其余各位数字不变。拟舍弃数字的最左一位数字大于 5 , 则进 一, 即保留数字的末位数字加 1 。拟舍弃数字的最左一位数字是 5 , 且其后有非 0 数字时进一, 即保留数字的 末位数字加 1 。拟舍弃数字的最左一位数字为 5 , 且其后无数字或皆为 0 时, 若所保留的末位数字为奇数 ( 1 , $3,5,7,9)$ 则进 1 , 即保留数字的末位数字加 1 ; 若所保留的末位数字为偶数 $(0,2,4,6,8)$, 则舍去。” 拟修 
约数字应一次修约获得结果, 不得多次连续修约。如: 15.49 修约到个位, 应一次修约为 15 , 不应先修约为 15.5 , 再修约为 16 。

\section{6 计量单位}

采用国际通用的计量单位和符号。例如, 毫米、厘米、米、千米、平方米、立方米的符号分别是 $\mathrm{mm}$ 、 $\mathrm{cm} 、 \mathrm{~m} 、 \mathrm{~km} 、 \mathrm{~m}^{2}$ 和 $\mathrm{m}^{3}$; 角单位度、分、秒的符号分别是 “o” “”” “””; 摄氏度为 ${ }^{\circ} \mathrm{C}$; 公顷为 $\mathrm{hm}^{2}$ 。

乔木层的高度单位用 $\mathrm{m}$, 例如, “大乔木层, 高度23 $35 \mathrm{~m}$ ”。地被层、草本层和灌木层的高度, 乔木 的胸径和灌木的地径单位用 $\mathrm{cm}$ 。例如, “大灌木层, 高度 $200 \sim 350 \mathrm{~cm}$; 小灌木层, 高度 $50 \sim 80 \mathrm{~cm}$ ”。乔木 层、灌木层、草本层和地被层的盖度, 一律用百分盖度表达。

组合单位使用 $\mathrm{g} /\left(\mathrm{m}^{2} \cdot \mathrm{a}\right) 、 \mathrm{t} /\left(\mathrm{hm}^{2} \cdot \mathrm{a}\right)$ 形式。

正文中标点符号、括号用全角; 局部英文中可用半角。英文字母后的圆点为半角。

\section{7 参考文献规范}

在每一卷册中，所有的参考文献在书后统一列出，各章节不单独列参考文献。

正文中引用文献时，采用著者-出版年制，即（著者姓氏，出版年）形式（中文著者用姓名）。两个著 者人名间用 “和” 连接 (英文用 “and”); 多于两个著者时, 只列第一著者, 后面加 “等” (英文用et al.)。 同著者同年份时，在年份后加a、b、c区别。

各文种的排列顺序为: 中文、日文、西文、俄文、其他文种。中文文献以姓名的汉语拼音字母为序。 每一篇文献原则上要列出全部作者姓名。第一作者相同时, 先排一人的, 再排两人的, 最后排多人的。西 文和俄文参考文献以字母为序, 统一姓在前, 名缩写在后。

参考文献中标点符号、括号用半角。具体著录项目、格式和标点符号如下:

a. 专著

主要责任者, 年份. 题名: 其他题目信息. 版本项(第1版不著录, 其他版本用阿拉伯数字、序数缩写形 式或其他标识表示). 出版地: 出版者: 开始页码-终止页码.

b. 期刊文章

主要责任者, 年份. 文章题名. 期刊名: 其他题名信息, 卷号（期号）：开始页码-终止页码.

c. 专著、论文集等的析出文献

析出文献主要责任者, 年份. 析出文献题名//专著主要责任者. 专著、论文集题名: 其他题名信息（如 卷号等). 出版地: 出版者: 开始页码-终止页码.

\section{d. 译著}

主要责任者, 年份. 书名. 译者, 译. 出版地: 出版者: 开始页码-终止页码.

e. 电子文献

电子文献中属以上 4 项的, 按以上规则著录, 引用页码改为[引用日期]. 获取和访问路径. DOI: (如有 且不包含在路径中）。其他电子资源按以下格式著录:

主要责任者, 出版年. 题名: 其他题名信息. 出版地: 出版者: 引文页码 (更新或修改日期) [引用日期]. 获取和访问路径. DOI: （如有且不包含在路径中）.

示例如下:

陈灵芝, 鲍显诚, 李才贵, 1964. 吉林省长白山北坡各垂直带内主要植物群落的某些结构特征. 植物生态学与地植物学丛刊, 2(2): 207-225.

吴征镒, 1991. 中国种子植物属的分布区类型. 云南植物研究, 增刊IV: 1-139.

吴征镒, 周浙昆, 李德铢, 彭华, 孙航, 2003. 世界种子植物科的分布区类型系统. 云南植物研究, 25(3), 245-257.

张新时, 1959. 东天山森林的地理分布/穆尔札耶夫. 新疆维吾尔自治区的自然条件论文集. 北京: 科学出版社: 201-226.

中国科学院新疆综合考查队, 中国科学院植物研究所, 1978. 新疆植被及其利用. 北京: 科学出版社.

中国科学院中国植被图编辑委员会, 2007. 中国植被及其地理格局一中华人民共和国植被图(1:1000 000)说明书. 地质出版社, 北京.

中国植被编辑委员会, 1980. 中国植被. 北京: 科学出版社.

Hill M O, 1979. TWINSPAN—A FORTRAN Program for Detrended Correspondence Analysis and Reciprocal Averaging. Ithaca: Cornell University.

Tichý L, Chytrý M, 2006. Statistical determination of diagnostic species for site groups of unequal size. Journal of Vegetation Science, 17(6): 809-818. 
附表1 植物群落调查表

Appendix Table 1 Sample table for plant community survey

附表1-1 植物群落样方调查基本信息记录表

Appendix Table 1-1 Sample table for basic information of a plot

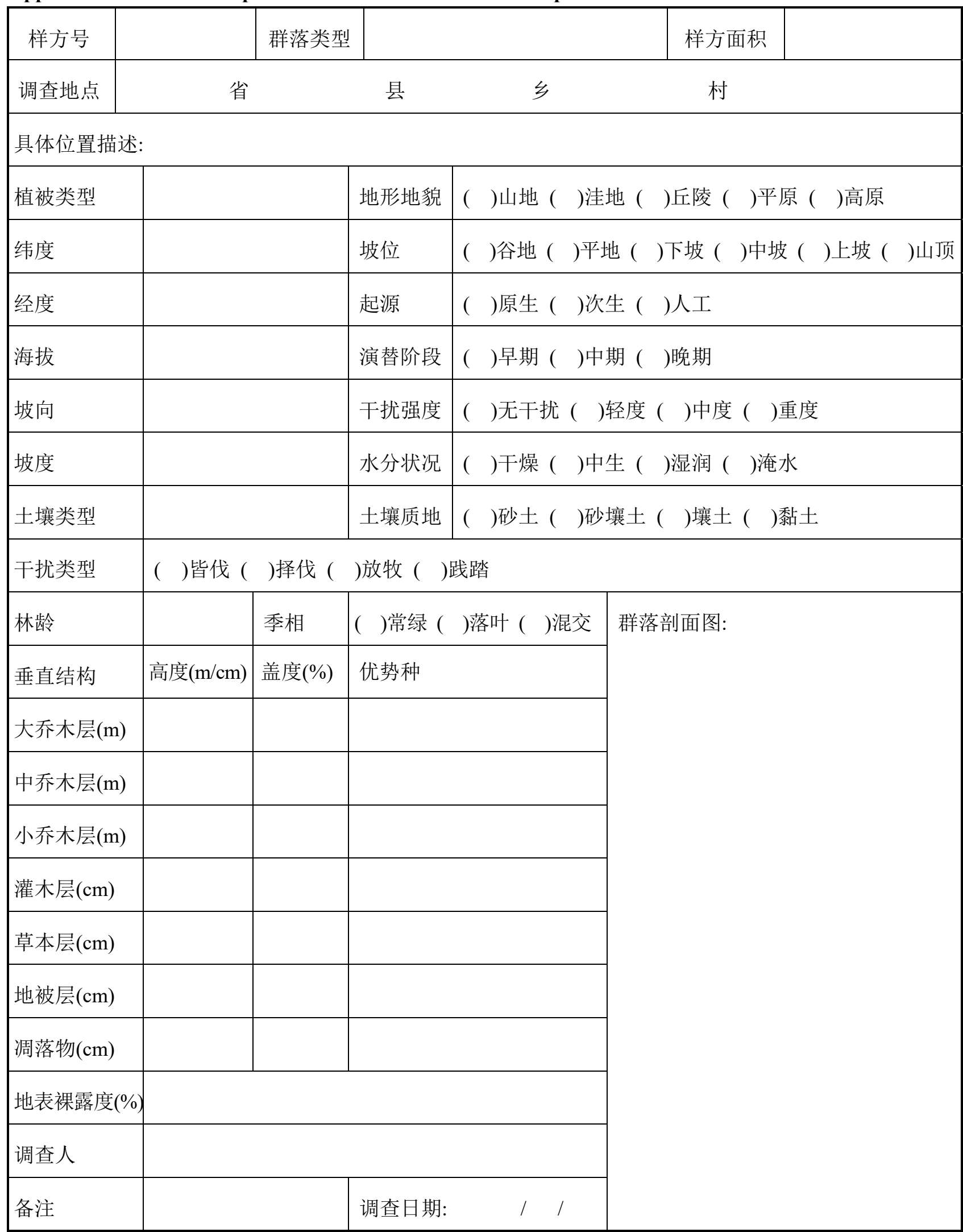




\section{植物群落样方调查基本信息记录表填写说明:}

1）表格中各项内容都必须如实填写，避免遗漏；设置了主要选项的变量，只需勾选即可。

2) 样方号: 可参考的编号规则为“地区和地点缩写 + (“群落类型缩写”) +样方序号”, 如在四川省米亚 罗的云杉林所建立的第3个样方编号为“SC-MYL-YSL-03”。

3) 群落类型和样方面积: 一般按“乔木层优势种-灌木层-草本层-地被层”命名, 如兴安落叶松林-杜香泥炭藓等。至少要记载冠层的优势种 (不止一个优势种的, 也列出), 如紫椴红松林、荆条-酸苯灌从等。样 方面积按实际填写, 例如可填写为: 600/100/1 $\mathrm{m}^{2}$, 表示乔木层、灌木层和草本层 (地被层) 的样方面积。

4）调查地点：样方所在的位置, 即省、县、乡、村或林业局、林场、小班, 并记录具体位置以便复查。

$5 ）$ 植被类型: 在9个类别中选一填入: 森林、灌从、草地、荒漠、高山冻原与稀疏植被、湿地、农业 植被、城市植被和无植被地段。其中, 森林可填写更详细一些, 例如针叶林、阔叶林、针叶与阔叶混交林。 针叶或阔叶树相对优势度 $\geqslant 75 \%$, 则为针叶或阔叶林, 否则为混交林。

6) 经纬度: 在获取经纬度时GPS至少需搜索到3颗以上卫星并等待读数稳定。样方经纬度野外记载采 用度分秒格式。

7) 海拔: 用海拔表确定样方所在地的海拔（在每个地点、不同天气条件下需重新校准）。在山区由于 手持GPS设备所测海拔高度的误差较大, 仅记录作为参考。

8) 坡向: 以方位角 $\left(0^{\circ}-360^{\circ}\right)$ 的格式记录。

9）坡度：样方的平均坡度。可用坡度测量仪或罗盘仪结合标杆进行测定。

10）地形地貌：在“山地、洼地、丘陵、平原、高原”中选一; 其他类型可直接填写。

11）坡位：在“谷地、平地、下坡、中坡、上坡、山顶”中选一; 其他类型可直接填写。

12）起源：在“原生、次生、人工”中选一; 其他类型可直接填写。

13 ）演替阶段：在“晚期、中期、早期”中选一; 其他类型可直接填写。

14）干扰类型和干扰强度: 干扰类型在 “皆伐、择伐、放牧、践踏” 中选一; 其他类型可直接填写。 干扰强度在“无干扰、轻度、中度、重度”中选一。

15）水分状况：在“干燥、中生、湿润、淹水”中选一, 可用手捏土壤判断; 其他类型可直接填写。

16）土壤类型：如暗棕壤、黄棕壤等。

17）土壤质地：在“砂土、砂壤土、壤土、黏土”中选一; 其他类型可直接填写。

18）林龄: 选择样方中胸径最大的树 10 株左右 (不少于 5 株), 采用生长雉钻取树干基部树芯测出树龄, 计算这些树龄平均值为林龄。人工林最好根据造林时间确定林龄。无相关信息的, 野外记录估计值, 年轮 测定结果出来后再补充准确林龄。

19）季相：在“常绿、落叶、混交”中选一。判断方法同针/阔叶林。

20）群落垂直结构：记录各垂直层的高度、盖度和优势种, 如某层有多个优势种, 要同时记录。按照 文中1.3.1节的方法, 现场绘制群落剖面图。

21 ) 各层高度: 各垂直层的目测或实测高度, 包括大乔木层 ( $\geqslant 25 \mathrm{~m})$ 、中乔木层 $(8 \sim 25 \mathrm{~m})$ 、小乔 木层 $(5 \sim 8 \mathrm{~m}) 3$ 个亚层、灌木层 $(50 \sim 500 \mathrm{~cm}$ ) 和草本层（含地被层， $<50 \mathrm{~cm}$ )。

22）各层盖度：用百分比表示。乔木层的盖度可采用百步抬头法测定。

23）地被层主要指由苔藓植物组成的层片。

24）调落物的盖度是样方内没有草本植物或苔藓生长且被调落物覆盖的部分所占的比例。优势种在调 落物一栏空缺或选填枯枝、落叶、球果等信息。

25）地表裸露度是指土表或岩石没有植物和调落物覆盖的部分所占的比例。

26）调查人及日期：如实填写。 
附表1-2 乔木层调查表

Appendix Table 1-2 Sample table for tree stratum of a plot

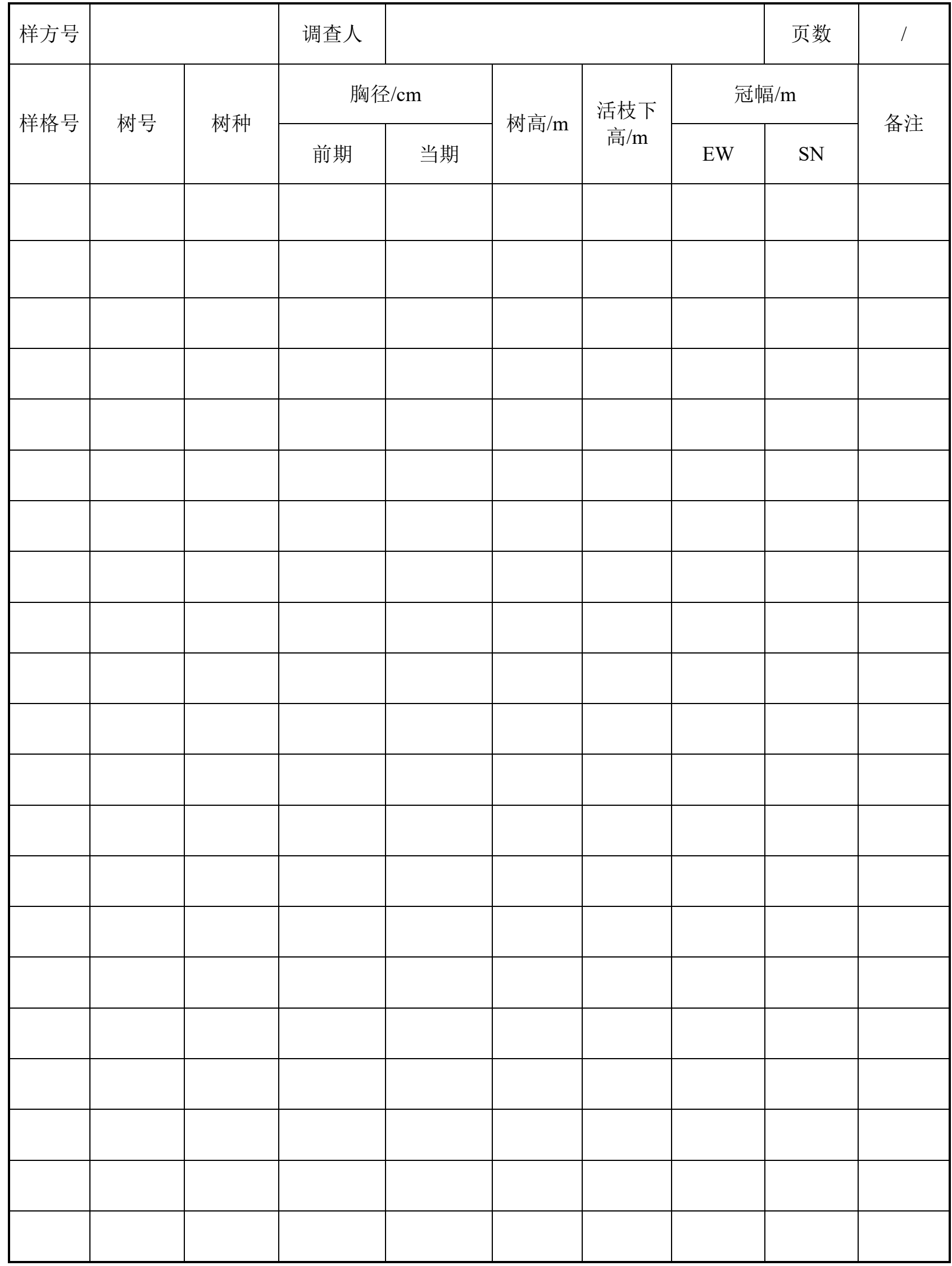

注: 每个样格树号重新起头从 1 开始, 如 $\mathrm{B} 01$ 。复查时, 进阶木填在上次所有样格之后, 并在每样格内继续向下编号。 


\section{乔木层调查表填写说明:}

（1）树种：记载树木的中文正名（土名等可记在备注中）。如遇到不能确定种名的个体，应当采集标 本或拍照并在备注栏中记录标本、照片号, 鉴定后及时补填树种名。植物种鉴定常用工具书包括《Flora of China》《中国植物志》《中国高等植物图鉴》《中国树木志》以及各种地方植物志等。

（2）胸径: 用胸径尺以及 $1.3 \mathrm{~m}$ 高的标杆在 $1.3 \mathrm{~m}$ 处进行测量, 填入 “当期胸径” 栏 ( “前期胸径” 为 样方复查时使用)。对于处于坡面上，生长不规则的树木，应按照如下方法测定胸径。

a）总是从上坡位方向测定;

b）对于倾斜或倒伏的个体，从下方而不是上方进行测定;

c）如树干表面附有藤蔓、绞杀植物和苔蘚等, 需去除后再测定;

d) 如不能直接测量胸径 (如分叉、粗大节、不规则肿大或萎缩), 应在合适位置测量, 测量点应标记, 以便复查;

e）胸高以下分枝的两个或两个以上茎干，可看作不同个体，分别进行测量；

f) 对具板根的树木在板根上方正常处测定, 并记录测量高度; 倒伏树干上如有萌发条, 只测量距根部 $1.3 \mathrm{~m}$ 以内的枝条。

(3) 树高、活枝下高: 树高可采用角规式、超声波和杆式测高器测量, 前两种在测定时需距离被测树 木一个树高以上 (否则无法准确看清树顶), 并须处理好坡度对测定的影响。活枝下高 (可选项目) 是指树 冠下第一主分枝的高度 (不含死枝), 测量方法同树高。

(4) 冠幅: 沿东西和南北两个方向, 用皮尺测量。

（5）在备注中注明树木健康状况，如折梢、枯顶、倾斜、倒伏、濒死、病虫害等。

(6) 大型木质藤本的调查, 与每木调查同步进行, 并在备注中注明 “藤本”。在树高一栏中填写估计 的藤本长度, 而不是高度。

（7）枯立木的调查, 与每木调查同步进行, 在备注中记录 “枯立木” 以及腐烂等级（判断方法可参见 《森林生态系统长期定位观测方法 (LY/T 1952-2011)》)。对于树冠大体完整的个体, 按活立木方法调查。 对于树干上部已有部分枯损折断的，需测定基径并估计树干顶部直径，记录在备注中。 
附表1-3 灌木层调查表

Appendix Table 1-3 Sample table for shrub stratum of a plot

\begin{tabular}{|c|c|c|c|c|c|c|c|c|}
\hline 样方号 & & & 调查人 & & & & 页数 & / \\
\hline 样格号 & 物种 & 基径/cm & 平均高度 $/ \mathrm{cm}$ & 冠幅a/cm & 冠幅b/cm & 株从数 & 盖度 $/ \%$ & 备注 \\
\hline & & & & & & & & \\
\hline & & & & & & & & \\
\hline & & & & & & & & \\
\hline & & & & & & & & \\
\hline & & & & & & & & \\
\hline & & & & & & & & \\
\hline & & & & & & & & \\
\hline & & & & & & & & \\
\hline & & & & & & & & \\
\hline & & & & & & & & \\
\hline & & & & & & & & \\
\hline & & & & & & & & \\
\hline & & & & & & & & \\
\hline & & & & & & & & \\
\hline & & & & & & & & \\
\hline & & & & & & & & \\
\hline & & & & & & & & \\
\hline & & & & & & & & \\
\hline & & & & & & & & \\
\hline & & & & & & & & \\
\hline & & & & & & & & \\
\hline & & & & & & & & \\
\hline
\end{tabular}

注：1）每个样格第一行在盖度栏记录样格灌木层总盖度；2）森林样方：在两个灌木样格调查完后, 对其他样格逐一进行踏查, 并记录新出现物种 的样格号、种名。 
附表1-4 草本层或地被层调查表

Appendix Table 1-4 Sample table for herb or ground stratum of a plot

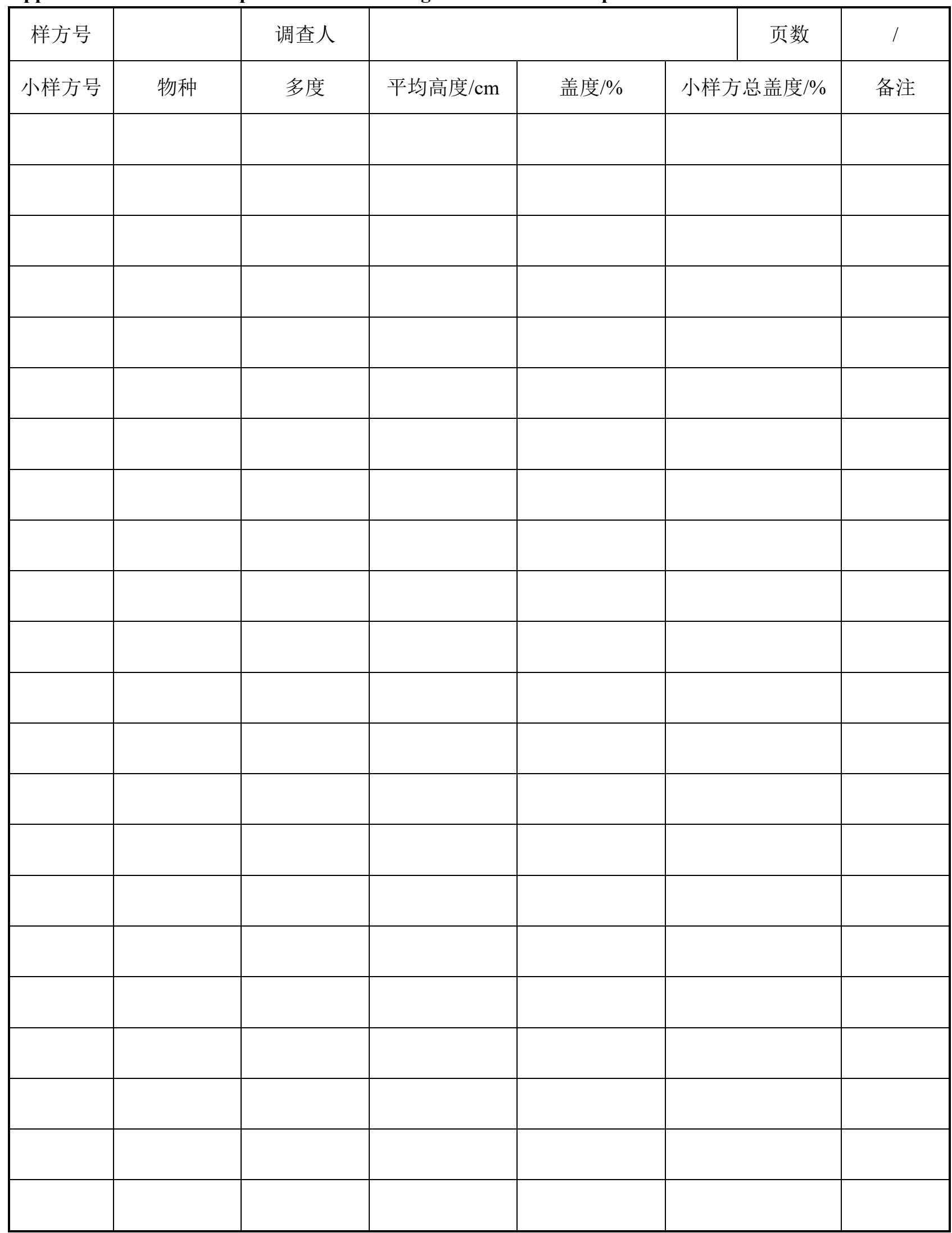

注: 1) “多度” 按德氏多度等级记录: 极多 (>100株) 记soc; 很多 (50 100株) 记cop3; 多 (30 50株) 记cop2；尚多 (10 30株) 记cop1；不多（5 10 株）记sp; 稀少 (2 5株) 记sol; 仅1株记un；2）样方总盖度：每个小样方的第一行记录整个小样方的草本层总盖度。 
附表2 植被类型海拔及气候因子的描述性统计汇总样表

Appendix Table 2 A sample table for the summary of altitude ranges and climatic factors of a vegetation type

例:

表 $\times \quad \times \times \times$ (群系组或群系名称)的海拔及气候因子的描述性统计 $(\boldsymbol{n}=$ 样点数 $)$

Table $x$ Descriptive statistics of altitude and climatic factors of $\times \times \times$ (name of an alliance group or an alliance) in China ( $n=$ number of plots)

\begin{tabular}{|c|c|c|c|c|c|}
\hline $\begin{array}{l}\text { 海拔及气候因子 } \\
\text { Altitude and climatic factors }\end{array}$ & $\begin{array}{l}\text { 平均值 } \\
\text { Mean value }\end{array}$ & $\begin{array}{l}\text { 标准误差 } \\
\text { Standard error }\end{array}$ & $\begin{array}{l}\text { 95\%置信区间 } \\
\text { 95\% confidence intervals }\end{array}$ & $\begin{array}{l}\text { 最小值 } \\
\text { Minimum }\end{array}$ & $\begin{array}{l}\text { 最大值 } \\
\text { Maximum }\end{array}$ \\
\hline \multicolumn{6}{|l|}{ 海拔 Altitude (m) } \\
\hline \multicolumn{6}{|l|}{ 年平均气温 Mean annual temperature $\left({ }^{\circ} \mathrm{C}\right)$} \\
\hline \multicolumn{6}{|l|}{ 最冷月平均气温 Mean temperature of the coldest month $\left({ }^{\circ} \mathrm{C}\right)$} \\
\hline \multicolumn{6}{|l|}{ 最热月平均气温 Mean temperature of the warmest month $\left({ }^{\circ} \mathrm{C}\right)$} \\
\hline \multicolumn{6}{|l|}{ 年降水量 Mean annual precipitation (mm) } \\
\hline \multicolumn{6}{|l|}{ 潜在蒸散 Potential evapotranspiration (mm) } \\
\hline \multicolumn{6}{|l|}{ 实际蒸散 Actual evapotranspiration (mm) } \\
\hline 湿润指数 Moisture index & & & & & \\
\hline
\end{tabular}

附表3 样方基本信息表(在Excel中, 此表要进行行列转置)

Appendix Table 3 Plot basic information (This table is to be transposed in Excel)

\begin{tabular}{|c|c|c|c|c|}
\hline 检索信息 & 编码 & 1 & 2 & $\cdots \cdots$ \\
\hline & 样方号 & & & \\
\hline 植被类型 & 植被名称 & & & \\
\hline \multirow{5}{*}{ 地理分布 } & 省区 & & & \\
\hline & 地点 & & & \\
\hline & 纬度 $\left({ }^{\circ} \mathrm{N}\right)$ & & & \\
\hline & 经度 $\left({ }^{\circ} \mathrm{E}\right)$ & & & \\
\hline & 海拔(m) & & & \\
\hline \multirow{7}{*}{ 生境信息 } & 地形地貌 & & & \\
\hline & 土壤类型 & & & \\
\hline & 土壤质地 & & & \\
\hline & 坡度 $\left(^{\circ}\right)$ & & & \\
\hline & 坡向 $\left(^{\circ}\right)$ & & & \\
\hline & 坡位 & & & \\
\hline & 水分状况 & & & \\
\hline \multicolumn{5}{|l|}{ 植被起源 } \\
\hline \multicolumn{5}{|l|}{ 演替阶段 } \\
\hline \multirow{2}{*}{ 干扰信息 } & 干扰类型 & & & \\
\hline & 干扰强度 & & & \\
\hline 乔木层 & 样方面积 $\left(\mathrm{m}^{2}\right)$ & & & \\
\hline 盖度 & 盖度(\%) & & & \\
\hline \multirow{3}{*}{ 胸径 } & 平均值 $(\mathrm{cm})$ & & & \\
\hline & 最小值(cm) & & & \\
\hline & 最大值(cm) & & & \\
\hline \multirow{3}{*}{ 高度 } & 平均值 (m) & & & \\
\hline & 最小值(m) & & & \\
\hline & 最大值(m) & & & \\
\hline 物种丰富度 & & & & \\
\hline
\end{tabular}


附表 3 (续) Appendix Table 3 (continued)

\begin{tabular}{|c|c|c|c|c|}
\hline 检索信息 & 编码 & 1 & 2 & $\ldots \ldots$ \\
\hline 灌木层 & 样方面积 $\left(\mathrm{m}^{2}\right)$ & & & \\
\hline \multirow{3}{*}{ 盖度 } & 平均值(\%) & & & \\
\hline & 最小值(\%) & & & \\
\hline & 最大值(\%) & & & \\
\hline \multirow{3}{*}{ 高度 } & 平均值 $(\mathrm{cm})$ & & & \\
\hline & 最小值 $(\mathrm{cm})$ & & & \\
\hline & 最大值 $(\mathrm{cm})$ & & & \\
\hline \multicolumn{5}{|l|}{ 物种丰富度 } \\
\hline 草本层 & 样方面积 $\left(\mathrm{m}^{2}\right)$ & & & \\
\hline \multirow{3}{*}{ 盖度 } & 平均值(\%) & & & \\
\hline & 最小值(\%) & & & \\
\hline & 最大值(\%) & & & \\
\hline \multirow{3}{*}{ 高度 } & 平均值 $(\mathrm{cm})$ & & & \\
\hline & 最小值 $(\mathrm{cm})$ & & & \\
\hline & 最大值 $(\mathrm{cm})$ & & & \\
\hline \multicolumn{5}{|l|}{ 物种丰富度 } \\
\hline 地被层 & 样方面积 $\left(\mathrm{m}^{2}\right)$ & & & \\
\hline \multirow{3}{*}{ 盖度 } & 平均值(\%) & & & \\
\hline & 最小值(\%) & & & \\
\hline & 最大值(\%) & & & \\
\hline \multirow{3}{*}{ 高度 } & 平均值 $(\mathrm{cm})$ & & & \\
\hline & 最小值 $(\mathrm{cm})$ & & & \\
\hline & 最大值 $(\mathrm{cm})$ & & & \\
\hline \multicolumn{5}{|l|}{ 物种丰富度 } \\
\hline 地表裸露度 & 地表裸露度(\%) & & & \\
\hline \multirow{2}{*}{ 凋落物 } & 调落物厚度 $(\mathrm{cm})$ & & & \\
\hline & 调落物覆盖度(\%) & & & \\
\hline \multicolumn{5}{|l|}{ 调查人 } \\
\hline \multicolumn{5}{|l|}{ 日期 } \\
\hline 备注 & & & & \\
\hline
\end{tabular}

附表4 样方数据汇总表

Appendix Table 4 A summary for plot data

\begin{tabular}{|c|c|c|c|c|c|c|c|c|c|}
\hline & 乔木层 t & & & & 密度 $\left(\text { 株 } / 600 \mathrm{~m}^{2}\right)^{*}$ & 胸径 $(\mathrm{cm})$ & 高度 $(\mathrm{m})$ & 频度 $(\%)$ & 重要值 \\
\hline & 灌木层 s & & & & 密度(株从/100 $\mathrm{m}^{2}$ ) & 盖度(\%) & 高度 $(\mathrm{cm})$ & 频度(\%) & 重要值 \\
\hline & 草本层 h & & & & 密度(株从 $/ 5 \mathrm{~m}^{2}$ )或德氏多度 & 盖度(\%) & 高度(cm) & 频度(\%) & 重要值 \\
\hline & 地被层 $\mathrm{m}$ & & & & & 盖度(\%) & 高度 $(\mathrm{cm})$ & 频度 $(\%)$ & 重要值 \\
\hline 样方号 & 层代码 ${ }^{* *}$ & 中文名 & 拉丁名 & 层号 & & & & & \\
\hline 样方1 & $\mathrm{t}$ & & & & & & & & \\
\hline 样方1 & $\mathrm{t}$ & & & & & & & & \\
\hline 样方1 & $\mathrm{s}$ & & & & & & & & \\
\hline 样方1 & $\mathrm{s}$ & & & & & & & & \\
\hline 样方1 & $\mathrm{h}$ & & & & & & & & \\
\hline 样方1 & $\mathrm{h}$ & & & & & & & & \\
\hline 样方1 & $\mathrm{m}$ & & & & & & & & \\
\hline 样方1 & $\mathrm{m}$ & & & & & & & & \\
\hline$\cdots$ & $\cdots$ & $\cdots$ & $\cdots$ & $\cdots$ & $\cdots$ & $\cdots$ & $\cdots$ & $\cdots$ & $\cdots$ \\
\hline
\end{tabular}

*各层的面积以实际调查的面积为准。** $\mathrm{t}:$ 乔木层; $\mathrm{s}$ : 灌木层; $\mathrm{h}$ : 草本层; $\mathrm{m}$ : 苔藓层。层号同表1。 
附表5 物种-样方数据表

Appendix Table 5 Species by plot data

\begin{tabular}{|c|c|c|c|c|c|c|c|}
\hline 群系或群系优势种科学 & & & & & & & \\
\hline & 层号 ${ }^{\#}$ & 样方 1 (阿拉伯数字组合) & 样方2 & $\cdots$ & $\cdots$ & $\cdots$ & $\cdots$ \\
\hline 物种1 (拉丁名, 下同) & 1 & 0 & 0 & 0 & 0 & $67^{*}$ & 0 \\
\hline 物种 2 & 1 & 0 & 0 & 0 & 0 & 0 & 0 \\
\hline$\ldots$ & ... & ... & $\ldots$ & $\ldots$ & $\ldots$ & $\ldots$ & ... \\
\hline
\end{tabular}

\#层号同表1。*重要值或相对盖度值, 数值范围 $0 \sim 100$ 。

附表6 植被描述中一些常用的地形、地貌术语的中英文对照及英文缩写

Appendix Table 6 A list of commonly used terms of terrain and landform for the description of vegetation

\begin{tabular}{|c|c|c|c|c|c|}
\hline $\begin{array}{l}\text { 中文 } \\
\text { Chinese }\end{array}$ & $\begin{array}{l}\text { 英文 } \\
\text { English }\end{array}$ & $\begin{array}{l}\text { 英文缩写 } \\
\text { English abbreviation }\end{array}$ & $\begin{array}{l}\text { 中文 } \\
\text { Chinese }\end{array}$ & $\begin{array}{l}\text { 英文 } \\
\text { English }\end{array}$ & $\begin{array}{l}\text { 英文缩写 } \\
\text { English abbreviation }\end{array}$ \\
\hline 冲积平原 & Alluvial Plain & AP & 沙地 & Sandland & SA \\
\hline 三角洲 & Delta & $\mathrm{D}$ & 戈壁 & Gobi & GO \\
\hline 冲积扇 & Alluvial Fan & $\mathrm{AF}$ & 风蚀残丘 & Deflation Monadnock & $\mathrm{DM}$ \\
\hline 波状平原 & Wavy Plain & WP & 剥蚀台地 & Deflation Platform & DP \\
\hline 台地 & Platform & $\mathrm{PF}$ & 雅丹 & Yardang Landform & YL \\
\hline 洼地 & Depression & $\mathrm{DE}$ & 风蚀洼地 & Deflation Hollow & $\mathrm{DH}$ \\
\hline 河谷 & Valley & VA & 冲沟 & Gully & GU \\
\hline 山地 & Mountain & MO & 西坡 & Western Slope & W \\
\hline 丘陵 & Hill & $\mathrm{HI}$ & 西北坡 & Northwestern Slope & NW \\
\hline 高原 & Plateau & PL & 北坡 & Northern Slope & $\mathrm{N}$ \\
\hline 喀斯特 & Karst & $\mathrm{KA}$ & 东北坡 & Northeastern Slope & $\mathrm{NE}$ \\
\hline 冰川 & Glacier & GL & 东坡 & Eastern Slope & $\mathrm{E}$ \\
\hline 阶地 & Terrace & $\mathrm{TE}$ & 东南坡 & Southeastern Slope & $\mathrm{SE}$ \\
\hline 河漫滩 & Floodplain & FL & 南坡 & Southern Slope & $\mathrm{S}$ \\
\hline 湖滩 & Lake Beach & LB & 西南坡 & Southwestern Slope & SW \\
\hline 沼泽 & Swamp & SWA & 下坡 & Lower Slope & LS \\
\hline 湖泊 & Lake & LA & 中坡 & Middle Slope & MS \\
\hline 海滩 & Beach & $\mathrm{BE}$ & 上坡 & Upper Slope & US \\
\hline 沙丘 & Dune & $\mathrm{DU}$ & 山顶或山脊 & Ridge & RI \\
\hline 丘间洼地 & Inter-Dune Depression & ID & & & \\
\hline
\end{tabular}

附表7 植被类型植物科属种组成汇总样表

Appendix Table 7 A sample table for the summary of taxonomic composition of a vegetation type

例:

表3.2 $\times \times \times$ (群系组或群系名称)的植物科属种组成

Table 3.2 Taxonomic composition in $\times \times \times$ (name of an alliance group or an alliance) in China

\begin{tabular}{|c|c|c|c|c|c|c|c|}
\hline $\begin{array}{l}\text { 群系 } \\
\text { Alliance }\end{array}$ & $\begin{array}{l}\text { 样方数 } \\
\text { Number of plots }\end{array}$ & $\begin{array}{l}\text { 全部植物 } \\
\text { All plants }\end{array}$ & $\begin{array}{l}\text { 苔蘚植物 } \\
\text { Bryophyte }\end{array}$ & $\begin{array}{l}\text { 蕨类植物 } \\
\text { Fern }\end{array}$ & $\begin{array}{l}\text { 裸子植物 } \\
\text { Gymnosperm }\end{array}$ & $\begin{array}{l}\text { 被子植物 } \\
\text { Angiosperm }\end{array}$ & $\begin{array}{l}\text { 含物种较多的 } 6 \text { 个科及物种数 } \\
\text { The most abundant } 6 \text { families }\end{array}$ \\
\hline & & 科/属/种 & 科/属/种 & 科/属/种 & 科/属/种 & 科/属/种 & \\
\hline & & $\mathrm{F} / \mathrm{G} / \mathrm{S}^{*}$ & $\mathrm{~F} / \mathrm{G} / \mathrm{S}$ & $\mathrm{F} / \mathrm{G} / \mathrm{S}$ & $\mathrm{F} / \mathrm{G} / \mathrm{S}$ & $\mathrm{F} / \mathrm{G} / \mathrm{S}$ & \\
\hline \multicolumn{8}{|l|}{ 群系1 } \\
\hline \multicolumn{8}{|l|}{ 群系2 } \\
\hline$\ldots$ & $\ldots$ & $\ldots$ & & $\ldots$ & $\ldots$ & $\ldots$ & $\ldots$ \\
\hline
\end{tabular}

* $\mathrm{F}=$ Family, $\mathrm{G}=$ Genus, $\mathrm{S}=$ Species 
附表8 植被类型种子植物区系成分汇总样表

Appendix Table 8 A sample table for the summary of the areal type of seed plant species of a vegetation type

例:

表3.3 $\times \times \times$ (群系组或群系名称) $\boldsymbol{n}$ 科 $\boldsymbol{m}$ 属种子植物的区系成分

Table 3.3 Areal type of the $n$ families and $\boldsymbol{m}$ genera of seed plant species recorded in $x \times x$ (name of an alliance group or an alliance)

\begin{tabular}{|c|c|c|c|c|c|}
\hline \multirow[t]{2}{*}{ 编号 No. } & \multirow[t]{2}{*}{ 分布区类型 Areal types } & \multicolumn{2}{|c|}{ 科 Family } & \multicolumn{2}{|c|}{ 属 Genus } \\
\hline & & 数量 Number & 比例/\% & 数量 Number & 比例 $/ \%$ \\
\hline 1 & 世界广布 Widespread & & & & \\
\hline 2 & 泛热带 Pantropic & & & & \\
\hline$\ldots$ & $\cdots$ & & & & \\
\hline 合计 Total & & & & & \\
\hline
\end{tabular}

注: 植物名录来自 $j$ 个样方记录

Note: The species list is recorded according to $j$ plots

附表9 植被类型植物生活型谱汇总样表

Appendix Table 9 A sample table for the summary of life-form spectrum of a vegetation type

例:

表3.4 $\times \times \times$ (群系组或群系名称) $\boldsymbol{n}$ 种植物的生活型谱 $(\%)$

Table 3.4 Life-form spectrum (\%) of the $n$ plant species recorded in $\times \times \times$ (name of an alliance group or an alliance)

\begin{tabular}{|c|c|c|c|c|c|c|c|c|c|c|c|c|c|c|c|c|c|}
\hline \multirow{2}{*}{$\begin{array}{c}\text { 木本植物 } \\
\text { Woody } \\
\text { plant }\end{array}$} & \multicolumn{2}{|c|}{ 乔木 Tree } & \multicolumn{4}{|c|}{ 灌木 Shrub } & \multicolumn{4}{|c|}{ 半灌木 Semi-shrub } & \multicolumn{3}{|c|}{ 藤本 Lianas } & \multirow{2}{*}{$\begin{array}{c}\text { 竹类 } \\
\text { Bam- } \\
\text { boo }\end{array}$} & \multirow[b]{2}{*}{$\begin{array}{l}\text { 蕨类 } \\
\text { Fern }\end{array}$} & \multirow[b]{2}{*}{$\begin{array}{c}\text { 附生 } \\
\text { Epiphyte }\end{array}$} & \multirow{2}{*}{$\begin{array}{l}\text { 寄生 } \\
\text { Phyto- } \\
\text { parasite }\end{array}$} \\
\hline & $\begin{array}{l}\text { 常绿 } \\
\text { Ever- } \\
\text { green }\end{array}$ & $\begin{array}{c}\text { 落叶 } \\
\text { Decid- } \\
\text { uous }\end{array}$ & $\begin{array}{l}\text { 常绿 } \\
\text { Ever- } \\
\text { green }\end{array}$ & $\begin{array}{l}\text { 落叶 } \\
\text { De- } \\
\text { ciduous }\end{array}$ & \begin{tabular}{|c|c|} 
肉质 \\
Succu- \\
lents
\end{tabular} & $\begin{array}{c}\text { 垫状 } \\
\text { Cushion }\end{array}$ & $\begin{array}{l}\text { 常绿 } \\
\text { Ever- } \\
\text { green }\end{array}$ & $\begin{array}{r}\text { 落口 } \\
\text { Deci } \\
\text { uou }\end{array}$ & $\begin{array}{c}\text { 肉质 } \\
\text { Succu- } \\
\text { lents }\end{array}$ & $\begin{array}{c}\text { 垫状 } \\
\text { Cushion }\end{array}$ & $\begin{array}{l}\text { 常绿 } \\
\text { Ever- } \\
\text { green }\end{array}$ & $\begin{array}{r}\text { 落 } \\
\text { Dec } \\
\text { uo }\end{array}$ & & & & & \\
\hline \multirow{2}{*}{$\begin{array}{c}\text { 陆生草本 } \\
\text { Terrestrial } \\
\text { herb }\end{array}$} & \multicolumn{10}{|c|}{$\begin{array}{c}\text { 多年生草本 } \\
\text { Perennial herb }\end{array}$} & \multicolumn{4}{|c|}{$\begin{array}{l}\text { 一年生草本 } \\
\text { Annual herb }\end{array}$} & $\begin{array}{l}\text { 蕨类 } \\
\text { Fern }\end{array}$ & $\begin{array}{c}\text { 寄生 } \\
\text { Phyto- } \\
\text { parasite }\end{array}$ & $\begin{array}{l}\text { 腐生 } \\
\text { Sapro- } \\
\text { phyte }\end{array}$ \\
\hline & $\begin{array}{c}\text { 从生类 } \\
\text { Tussock- } \\
\text { grass }\end{array}$ & $\begin{array}{c}\text { 根茎类 } \\
\text { Rhizome- } \\
\text { grass }\end{array}$ & \multicolumn{2}{|c|}{$\begin{array}{l}\text { 直立 } \\
\text { 杂类 } \\
\text { Forb }\end{array}$} & $\begin{array}{c}\text { 蔓生攀援 } \\
\text { Liana }\end{array}$ & $\begin{array}{c}\text { 莲座 } \\
\text { Rosette- } \\
\text { herb }\end{array}$ & \multicolumn{2}{|c|}{$\begin{array}{c}\text { 垫状 } \\
\text { Cushion- } \\
\text { herb }\end{array}$} & $\begin{array}{c}\text { 肉质 } \\
\text { Succulent }\end{array}$ & $\begin{array}{c}\text { 附生 } \\
\text { Epiphyte }\end{array}$ & \multicolumn{2}{|c|}{$\begin{array}{c}\text { 短生型 } \\
\text { Ephemeral } \\
\text { annual }\end{array}$} & \multicolumn{2}{|c|}{$\begin{array}{c}\text { 非短生型 } \\
\text { None } \\
\text { ephemeral } \\
\text { annual }\end{array}$} & & & \\
\hline $\begin{array}{c}\text { 水生草本 } \\
\text { Aquatic } \\
\text { herb }\end{array}$ & $\begin{array}{c}\text { 挺水 } \\
\text { Emerged }\end{array}$ & $\begin{array}{c}\text { 浮叶 } \\
\text { Floating } \\
\text { leaf }\end{array}$ & & \begin{tabular}{l|l} 
ating & $\mathrm{S}$ \\
atis
\end{tabular} & $\begin{array}{c}\text { 沉水 } \\
\text { Submerged }\end{array}$ & & & & & & & & & & & & \\
\hline $\begin{array}{c}\text { 原植体 } \\
\text { 植物 } \\
\text { (叶状体 } \\
\text { 植物) } \\
\text { Thallo- } \\
\text { phytes }\end{array}$ & $\begin{array}{l}\text { 苔藓 } \\
\text { Moss }\end{array}$ & $\begin{array}{l}\text { 地衣 } \\
\text { Lichen }\end{array}$ & & $\begin{array}{l}\text { 荣类 } \\
\operatorname{lgae}\end{array}$ & $\begin{array}{l}\text { 菌类 } \\
\text { Fungi }\end{array}$ & & & & & & & & & & & & \\
\hline & & & & & & & & & & & & & & & & & \\
\hline
\end{tabular}

注: 植物名录来自 $j$ 个样方记录

Note: The species list is recorded according to $j$ plots 